\title{
Ochratoxin A: 50 Years of Research
}

\author{
Frantisek Malir ${ }^{1, *}$, Vladimir Ostry ${ }^{2}$, Annie Pfohl-Leszkowicz ${ }^{3, *}$, Jan Malir ${ }^{4}$ and Jakub Toman ${ }^{1}$ \\ 1 Department of Biology, Faculty of Science, University of Hradec Kralove, Hradec Kralove 50003, \\ Czech Republic; jakub.toman.1@uhk.cz \\ 2 National Reference Center for Microfungi and Mycotoxins in Food Chains, Center of Health, \\ Nutrition and Food in Brno, National Institute of Public Health in Prague, Brno 61242, Czech Republic; \\ ostry@chpr.szu.cz \\ 3 Department Bioprocess \& Microbial Systems, Laboratory Chemical Engineering, INP/ENSA Toulouse, \\ University of Toulouse, UMR 5503 CNRS/INPT/UPS, Auzeville-Tolosane 31320, France \\ 4 Institute of State and Law, Czech Academy of Sciences, Narodni 18, Prague 11600, Czech Republic; \\ jan.malir@ilaw.cas.cz \\ * Correspondence: frantisek.malir@uhk.cz (F.M.); leszkowicz@ensat.fr (A.P.-L.); \\ Tel./Fax: +420-493-331-183 (F.M.); +335 621-939-47 (A.P.-L.)
}

Academic Editor: Richard A. Manderville

Received: 26 April 2016; Accepted: 13 June 2016; Published: 4 July 2016

\begin{abstract}
Since ochratoxin A (OTA) was discovered, it has been ubiquitous as a natural contaminant of moldy food and feed. The multiple toxic effects of OTA are a real threat for human beings and animal health. For example, OTA can cause porcine nephropathy but can also damage poultries. Humans exposed to OTA can develop (notably by inhalation in the development of acute renal failure within $24 \mathrm{~h}$ ) a range of chronic disorders such as upper urothelial carcinoma. OTA plays the main role in the pathogenesis of some renal diseases including Balkan endemic nephropathy, kidney tumors occurring in certain endemic regions of the Balkan Peninsula, and chronic interstitial nephropathy occurring in Northern African countries and likely in other parts of the world. OTA leads to DNA adduct formation, which is known for its genotoxicity and carcinogenicity. The present article discusses how renal carcinogenicity and nephrotoxicity cause both oxidative stress and direct genotoxicity. Careful analyses of the data show that OTA carcinogenic effects are due to combined direct and indirect mechanisms (e.g., genotoxicity, oxidative stress, epigenetic factors). Altogether this provides strong evidence that OTA carcinogenicity can also occur in humans.
\end{abstract}

Keywords: ochratoxin A; microfungi; food; feed; toxicity; Balkan endemic nephropathy; carcinogenicity; urothelial cancer; biomarkers

\section{Introduction}

Ochratoxin A (OTA) is one of the most important and deleterious mycotoxins [1,2].

OTA was isolated and chemically characterized in 1965 [3,4]. OTA was discovered in South Africa as a toxic metabolite of Aspergillus ochraceus in a corn meal that was intentionally inoculated with this microfungus [3]. Further research has shown that OTA is nephrotoxic, hepatotoxic, embryotoxic, teratogenic, neurotoxic, immunotoxic, genotoxic, and carcinogenic in many species with species and sex-related differences [5-10]. The International Agency for Research on Cancer classified OTA as a possible human carcinogen (group 2B) in 1993 based on a great amount of evidence of its carcinogenity discovered in several animal studies [11]. The susceptibility to cancer is species- and sex-dependent $[8,9,12-15]$. Frequent exposure of animals or humans to OTA may cause a range of health problems. In particular, OTA could be a threat of cancer for humans. It will be shown further in this article that OTA acts as a nephrotoxin and an urothelial carcinogen as a result of both the oxidative stress and direct genotoxic mechanisms. Strikingly, chronic exposure to low OTA doses 
could be even more damaging than acute exposure to a high dose [16,17]. Humans are normally exposed to OTA - as they are to other mycotoxins—-through several routes, dietary intake being the most prominent. Dermal contact or inhalation exposures are of a minor importance with respect to the general population [18], although, occasionally, these routes may also play a role [19,20].

In this paper, we attempt to review the data on OTA research from its discovery. The principal milestones in OTA research in 1965-1990, 1991-2000, and 2000-2015 are summarized in Figures 1-3. 


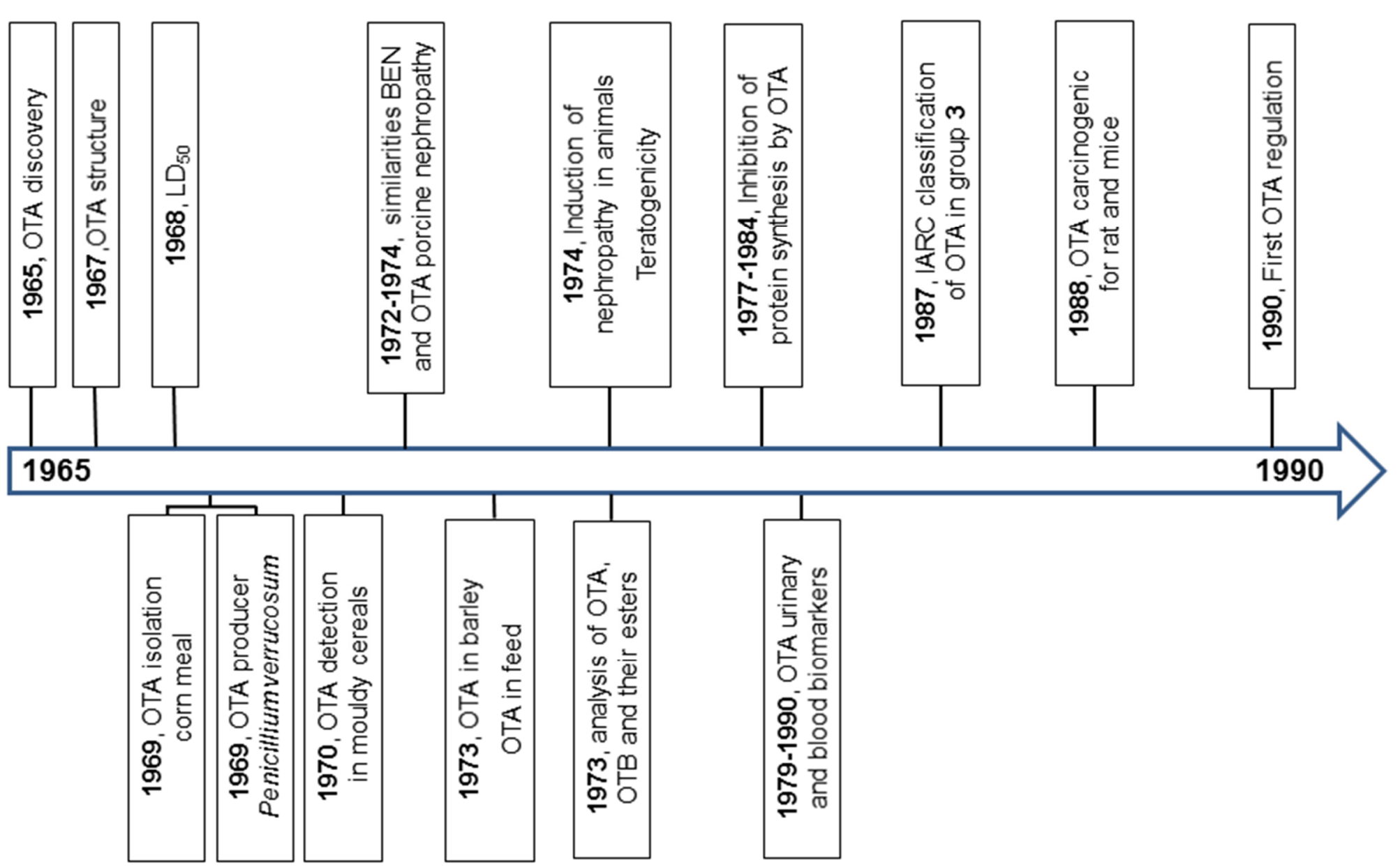

Figure 1. The milestones in ochratoxin A (OTA) research in years 1965-1990. 


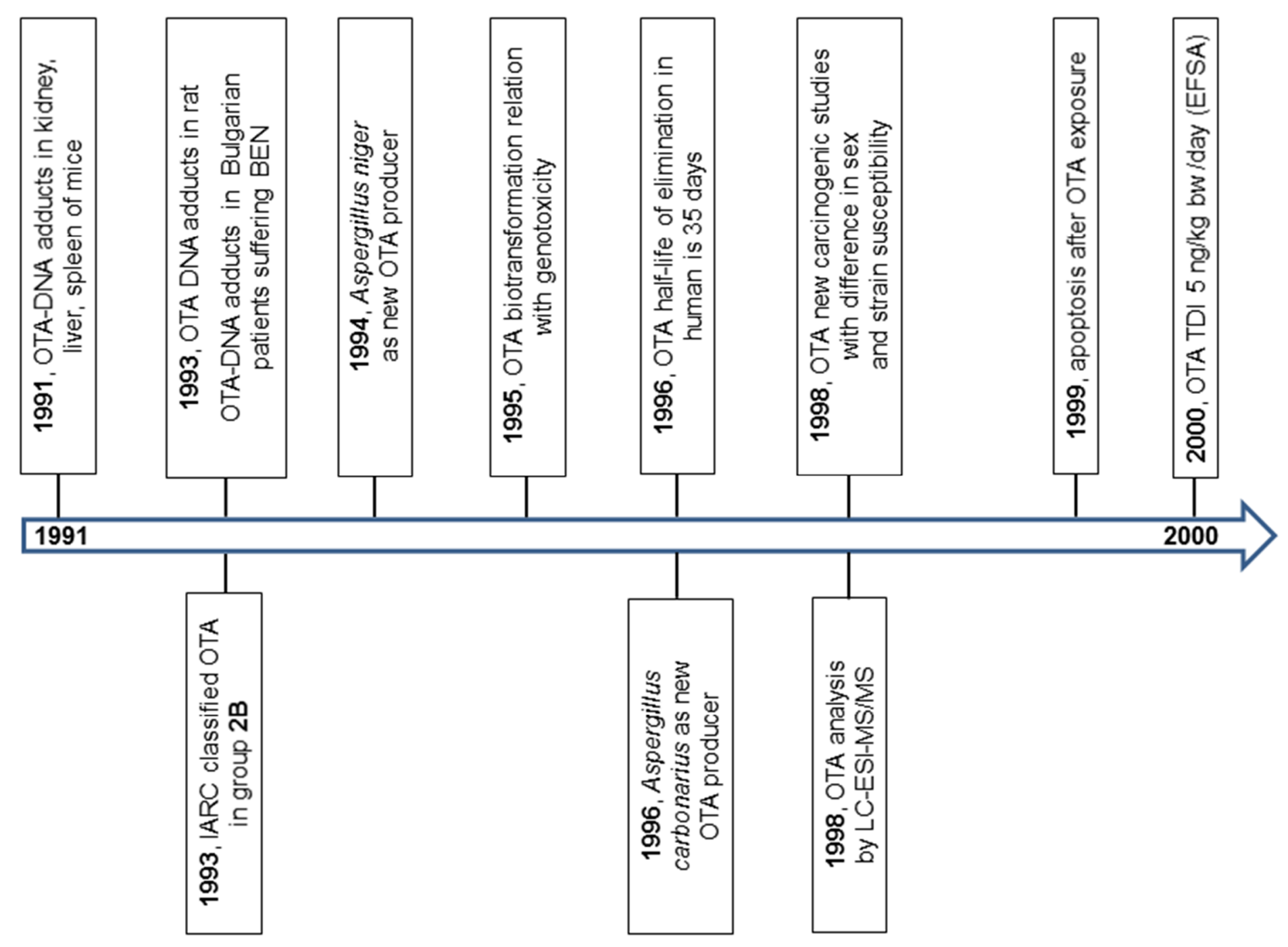

Figure 2. The milestones in OTA research in years 1991-2000. 


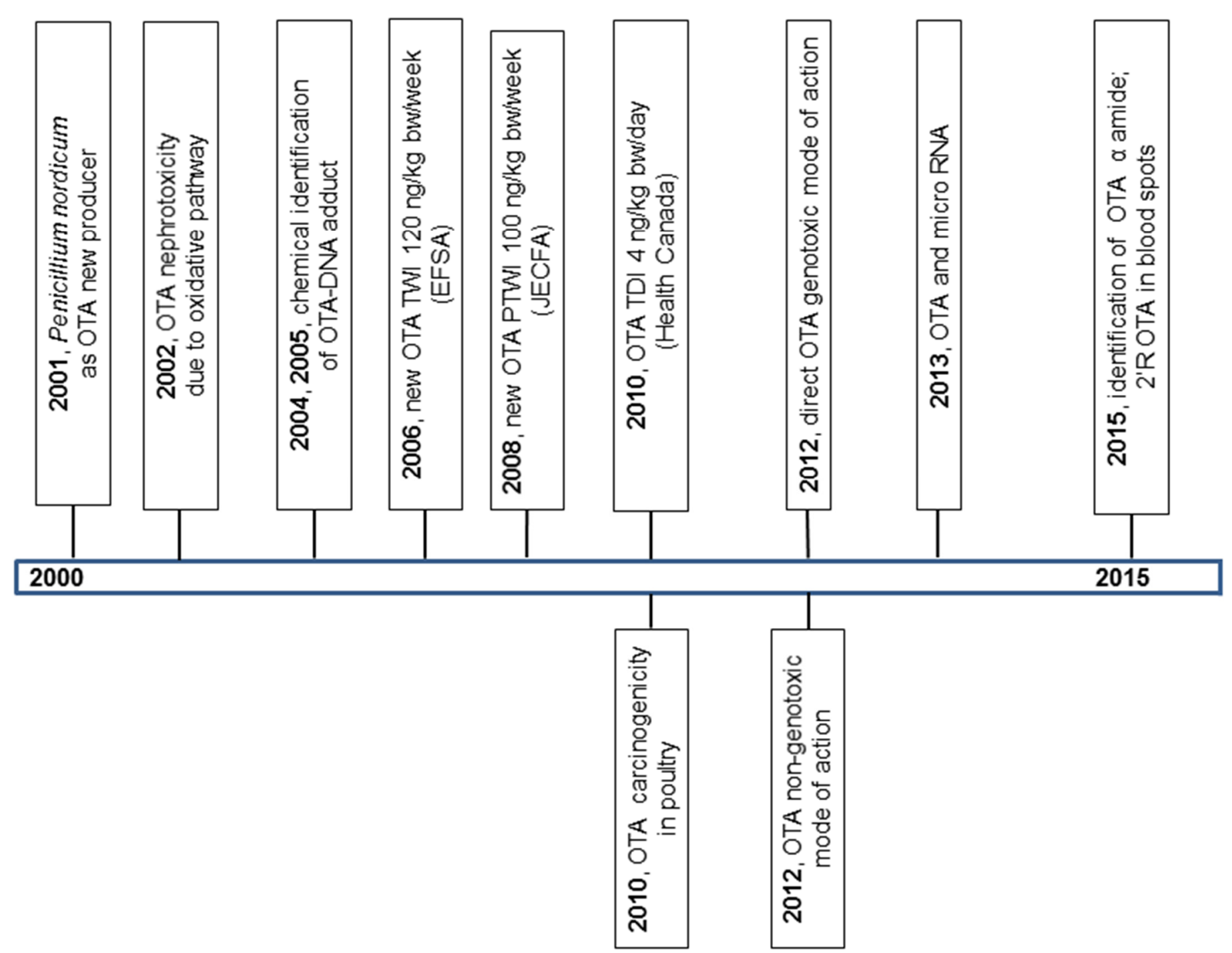

Figure 3. The milestones in OTA research in years 2000-2015. 


\section{OTA Producers in Foodstuffs}

Aspergillus ochraceus was the first producer of OTA ever identified. OTA was first discovered in corn meal intentionally inoculated with Aspergillus ochraceus [3]. Then, in a survey on OTA occurrence, producing strains isolated from feedstuffs, 2/19 isolates of Aspergillus niger var. niger were able to produce OTA in medium containing $2 \%$ yeast extract and $15 \%$ of sucrose broth, and in maize cultures. This was the first report on the production of OTA by Aspergillus niger [21]. Furthermore, Teren et al. (1996) tested 157 strains belonging to Aspergillus section Nigri for OTA production [22]. OTA was also detected in the culture filtrates of 5/12 Aspergillus carbonarius strains and 3/100 isolates in the A. niger aggregate (A. foetidus and A. niger). OTA-producing Aspergillus species, A. carbonarius (and the closely related $A$. niger which produces OTA more rarely), grow well at high temperatures and produce pigmented hyphae and spores, making these species resistant to UV light. Consequently, A. carbonarius is commonly found in grapes and similar fruits that mature in sunlight and at high temperatures [23]. The ability of Aspergillus tubingensis to produce OTA and the influence of grape variety on the occurrence of OTA-producing fungi in grapes were described for the first time in 2005 [24]. New OTA-producing species of Aspergillus section, Circumdati A. westerdijkiae and A. steynii isolated from coffee, were discovered in 2004 [25]. Moreover, Samson et al. (2004) found new OTA-producing species in Aspergillus section Nigri-Aspergillus lacticoffeatus and A. sclerotioniger-which were also isolated from coffee [26].

In 1969, Walbeek et al. isolated OTA from Penicillium viridicatum [27]. Due to considerable revisions in taxonomy, particularly within the genus Penicillium, and ensuing difficulties in correct assignation, this identity has changed over the years [28]. Several authors have drawn attention to the fact that isolates of Penicillium viridicatum as defined at that time could be now divided into three groups depending on their various properties, including growth rates, mycotoxin production, and source $[28,29]$. Penicillium viridicatum isolates from group I grow rapidly, and they are first bright yellow green and turn forest green with age. They are mostly isolated from moldy grain but have not been found to produce either OTA or citrinin (CIT). P. viridicatum isolates from group II grow slowly and are yellow green both at maturity and in age. They are isolated from various plant sources, and produce both OTA and citrinin. P. viridicatum isolates from group III grow moderately quickly and turn brown with age. They come from meat or meatpacking plants in Europe. These latter isolates produce OTA when freshly isolated, but have not been found to produce citrinin. The taxonomy of $P$. viridicatum and $P$. verrucosum has been reviewed to clarify the conflict relating to the three P. viridicatum groups as laid down by Ciegler et al. (1973) [29]. It has been concluded that P. viridicatum group II corresponds to P. verrucosum and not to P. viridicatum, as indicated by Pitt (1979) [30]. Among species in subgenus Penicillium, only P. verrucosum is known to produce OTA. The main food habitat for $P$. verrucosum appears to be cereals growing in cool temperate zones, ranging across Northern and Central Europe and Canada [23]. In 2001, Penicillium nordicum was determined and confirmed as the second OTA-producing Penicillium species along with P. verrucosum [31]. Despite their shared ability to produce OTA, Larsen et al. (2001) claimed that the two species differ in several ways [31]. P. nordicum and P. verrucosum occupy different ecological niches. OTA-producing isolates originating from plant-derived material are almost always contaminated by $P$. verrucosum, whereas OTA producers in meat or cheese are derived from P. nordicum. Under many laboratory conditions, P. nordicum produces more OTA than $P$. verrucosum isolates, and lack to produce citrinin $[31,32]$.

Tables 1 and 2 provide an overview of the current identity of microfungi Aspergillus and Penicillium species, which are capable of producing OTA in foodstuffs [33]. 
Table 1. Aspergillus species as OTA producers in foodstuffs.

\begin{tabular}{|c|c|c|c|c|}
\hline Genera & Section & Species & Foodstuffs (Examples) & Year of Discovery \\
\hline \multirow{9}{*}{ Aspergillus } & \multirow{3}{*}{ Circumdati } & A. ochraceus G. Wilh. & Soya bean, nuts, red pepper, cereals, green coffee beans & 1965 \\
\hline & & A. steynii Frisvad \& Samson & Coffee beans & 2004 \\
\hline & & A. westerdijkiae Frisvad \& Samson & Coffee beans & 2004 \\
\hline & \multirow{6}{*}{ Nigri } & A. carbonarius (Bainier) Thom & Grapes, red pepper, coffee beans & 1996 \\
\hline & & A. foetidus Thom \& Raper & Grapes & 1996 \\
\hline & & A. lacticoffeatus Frisvad \& Samson & Coffee beans & 2004 \\
\hline & & A. niger Tiegh. & Grapes, peanuts & 1994 \\
\hline & & A. sclerotioniger Frisvad \& Samson & Coffee beans & 2004 \\
\hline & & A. tubingensis Mosseray & Grapes & 2005 \\
\hline
\end{tabular}

Table 2. Penicillium species as OTA producers in foodstuffs.

\begin{tabular}{cccccc}
\hline Genera & Subgenus & Series & Species & Foodstuffs (Examples) & Year of Discovery \\
\hline \multirow{2}{*}{ Penicillium } & \multirow{2}{*}{ Penicillium } & Verrucosa & P. verrucosum Dierckx & Cereals & 1969 \\
& & Verrucosa & P. nordicum Dragoni \& Marino & Dry ham, salami & 2001 \\
\hline
\end{tabular}




\section{OTA Chemistry}

\subsection{Chemical Characterization of OTA}

CAS name (Chemical Abstracts Services) Registry No.: 303-47-9.

Chemical Abstracts: L-Phenylalanine, $\mathrm{N}$-[(5-chloro-3,4-dihydro-8-hydroxy-3-methyl-1-oxo-1- $\mathrm{H}$ 2-benzopyran-7-yl)carbonyl]-, (R)-.

IUPAC name: (N-[[(3R)-5-chloro-8-hydroxy-3-methyl-1-oxo-7-isochromanyl] carbonyl]-3-phenylL-alanine).

Other name: (-)-N-[(5-chloro-8-hydroxy-3-methyl-1-oxo-7-isochromanyl) carbonyl]-3-phenylalanine.

Summary formula: $\mathrm{C}_{20} \mathrm{H}_{18} \mathrm{O}_{6} \mathrm{ClN}$.

OTA consists of a para-chlorophenolic moiety containing a dihydroiso-coumarin group that is amide-linked to L-phenylalanine. See Figure 4 and Table 3 for structure of the OTA derivatives.

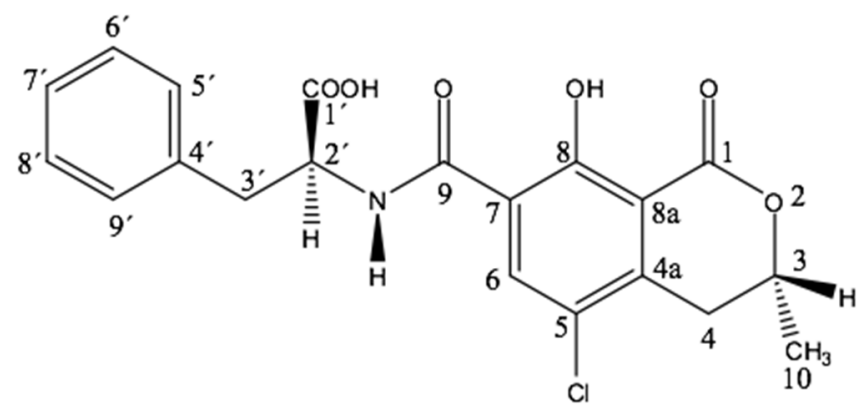

Figure 4. Structural formula of OTA.

Molecular Weight: 403.8.

Chemical and physical properties of OTA were comprehensively described by Budavari (1989) [34] and IARC (1993) [11], its melting point was determined by van der Merwe et al. (1965) [3,4] and Kuiper-Goodman and Scott (1989) [35], and its optical rotation by Pohland et al. (1982) [36]. Spectroscopic data on OTA (as ultraviolet, infrared, mass spectral and proton nuclear magnetic resonance data) were reported by van der Merwe et al. (1965) [3,4] and Pohland et al. (1982) [36], OTA solubility (e.g., in chloroform, ethanol, methanol, xylene) by WHO (1990) [37], and its stability (partial degradation under normal cooking conditions) by Müller (1982) [38]. OTA degradation was performed by treatment with an excess of sodium hypochlorite solution [39]. Physico-chemical properties of OTA and the progress in their knowledge have been recently reviewed in great detail by Khoury and Atoui (2010) [40]. OTA is a weak acid with two pka (4 and 7) [41].

Table 3 described several derivatives occurring naturally or formed in the body after biotransformation. Some are hydroxylated, others lack phenylalanine moiety or are conjugated (e.g., with glutathione, glucuronic acid, sulfate, or pentose) [40,42-50]. 
Table 3. Chemical structures of OTA and its derivatives.

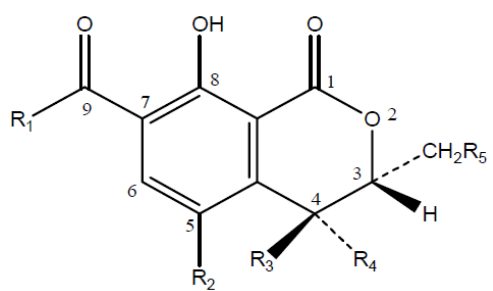

\begin{tabular}{|c|c|c|c|c|c|c|c|c|c|}
\hline Metabolites & Abbreviations & MW & R1 & $\mathbf{R} 2$ & R3 & $\mathbf{R} 4$ & R5 & R6 & References \\
\hline Ochratoxin A & OTA & 403 & Phe & $\mathrm{Cl}$ & $\mathrm{H}$ & $\mathrm{H}$ & $\mathrm{H}$ & $\mathrm{OH}$ & {$[3,4]$} \\
\hline Ochratoxin B & ОТВ & 370 & Phe & $\mathrm{H}$ & $\mathrm{H}$ & $\mathrm{H}$ & $\mathrm{H}$ & $\mathrm{OH}$ & [51] \\
\hline Ochratoxin C & отC & 431 & Phe Ethyl ester & $\mathrm{Cl}$ & $\mathrm{H}$ & $\mathrm{H}$ & $\mathrm{H}$ & $\mathrm{OH}$ & [52] \\
\hline Ochratoxin $\alpha$ & OT $\alpha$ & 256 & $\mathrm{OH}$ & $\mathrm{Cl}$ & $\mathrm{H}$ & $\mathrm{H}$ & $\mathrm{H}$ & $\mathrm{OH}$ & [53] \\
\hline Ochratoxin $\beta$ & OT $\beta$ & 223 & $\mathrm{OH}$ & $\mathrm{H}$ & $\mathrm{H}$ & $\mathrm{H}$ & $\mathrm{H}$ & $\mathrm{OH}$ & [54] \\
\hline 4R-hydroxy Ochratoxin A & 4R-OHOA & 419 & Phe & $\mathrm{Cl}$ & $\mathrm{H}$ & $\mathrm{OH}$ & $\mathrm{H}$ & $\mathrm{OH}$ & [55] \\
\hline 4S-hydroxy Ochratoxin A & 4S-OHOA & 419 & Phe & $\mathrm{Cl}$ & $\mathrm{OH}$ & $\mathrm{H}$ & $\mathrm{H}$ & $\mathrm{OH}$ & [55] \\
\hline 10-hydroxy Ochratoxin A & 10-OHOA & 419 & Phe & $\mathrm{Cl}$ & $\mathrm{H}$ & $\mathrm{H}$ & $\mathrm{OH}$ & $\mathrm{OH}$ & [56] \\
\hline Ochratoxin A open lactone & OP-OA & 421 & Phe & $\mathrm{Cl}$ & $\mathrm{H}$ & $\mathrm{H}$ & - & $\mathrm{OH}$ & [57] \\
\hline Ochratoxin B open lactone & OP-OB & 388 & Phe & $\mathrm{H}$ & $\mathrm{H}$ & $\mathrm{H}$ & - & $\mathrm{OH}$ & [57] \\
\hline Ochratoxin $\alpha$ open lactone & OP-OT $\alpha$ & 274 & $\mathrm{OH}$ & $\mathrm{Cl}$ & $\mathrm{H}$ & $\mathrm{H}$ & - & $\mathrm{OH}$ & [57] \\
\hline Ochratoxin $\beta$ open lactone & OP-OT $\beta$ & 241 & $\mathrm{OH}$ & $\mathrm{H}$ & $\mathrm{H}$ & $\mathrm{H}$ & - & $\mathrm{OH}$ & [57] \\
\hline Ochratoxin A quinone & OTQ & 383 & Phe & $\mathrm{O}$ & $\mathrm{H}$ & $\mathrm{H}$ & $\mathrm{H}$ & $\mathrm{O}$ & [58] \\
\hline Ochratoxin A hydroquinone & OTHQ & 385 & Phe & $\mathrm{OH}$ & $\mathrm{H}$ & $\mathrm{H}$ & $\mathrm{H}$ & $\mathrm{OH}$ & [58] \\
\hline OTHQ decarboxylated & DC-OTHQ & 366 & Decarboxylated Phe & $\mathrm{OH}$ & $\mathrm{H}$ & $\mathrm{H}$ & $\mathrm{H}$ & $\mathrm{OH}$ & [43] \\
\hline Conjugate Ochratoxin A quinone-glutathion & OTQ-Glutathion & 689 & Phe & $\mathrm{O}$ & $\mathrm{H}$ & $\mathrm{H}$ & $\mathrm{H}$ & $\mathrm{O}$ & [59] \\
\hline Conjugate Ochratoxin A-acyl hexose & Acyl-hexose-OTA & 565 & Phe acyl hexose & $\mathrm{Cl}$ & $\mathrm{H}$ & $\mathrm{H}$ & $\mathrm{H}$ & $\mathrm{OH}$ & [60] \\
\hline Conjugate Ochratoxin A-acyl pentose & Acyl-pentose OTA & 535 & Phe acyl pentose & $\mathrm{Cl}$ & $\mathrm{H}$ & $\mathrm{H}$ & $\mathrm{H}$ & $\mathrm{OH}$ & [60] \\
\hline Ochratoxin A methyl ester & OTA-Me & 417 & Phe methyl ester & $\mathrm{Cl}$ & $\mathrm{H}$ & $\mathrm{H}$ & $\mathrm{H}$ & $\mathrm{OH}$ & [57] \\
\hline Ochratoxin B methyl ester & OTB-Me & 384 & Phe methyl ester & $\mathrm{H}$ & $\mathrm{H}$ & $\mathrm{H}$ & $\mathrm{H}$ & $\mathrm{OH}$ & [57] \\
\hline Ochratoxin B ethyl ester & OTB-Et & 398 & Phe ethyl ester & $\mathrm{H}$ & $\mathrm{H}$ & $\mathrm{H}$ & $\mathrm{H}$ & $\mathrm{OH}$ & [57] \\
\hline 4R-hydroxy Ochratoxin A methyl ester & 4R-OHOA-Me & 433 & Phe methyl ester & $\mathrm{Cl}$ & $\mathrm{H}$ & $\mathrm{OH}$ & $\mathrm{H}$ & $\mathrm{OH}$ & [57] \\
\hline 10-hydroxy Ochratoxin A methyl ester & 10-OHOA-Мe & 433 & Phe methyl ester & $\mathrm{Cl}$ & $\mathrm{H}$ & $\mathrm{H}$ & $\mathrm{OH}$ & $\mathrm{OH}$ & [57] \\
\hline Ethylamide Ochratoxin A & OE-OA & 430 & Phe ethyl amide & $\mathrm{Cl}$ & $\mathrm{H}$ & $\mathrm{H}$ & $\mathrm{H}$ & $\mathrm{OH}$ & [61] \\
\hline Ochratoxin A decarboxylated & DC-OA & 359 & Phe decarboxylated & $\mathrm{Cl}$ & $\mathrm{H}$ & $\mathrm{H}$ & $\mathrm{H}$ & $\mathrm{OH}$ & [61] \\
\hline Ochratoxin A O-methyl & OM-OA & 417 & Phe & $\mathrm{Cl}$ & $\mathrm{H}$ & $\mathrm{H}$ & $\mathrm{H}$ & $\mathrm{OCH}_{3}$ & [61] \\
\hline$d$-Ochratoxin A & $d-\mathrm{OA}$ & 403 & $d$-Phe & $\mathrm{Cl}$ & $\mathrm{H}$ & $\mathrm{H}$ & $\mathrm{H}$ & $\mathrm{OH}$ & {$[61]$} \\
\hline Ochratoxin $\alpha$ ester methyl & $\mathbf{M}-\mathbf{O} \alpha$ & 270 & $\mathrm{OCH}_{3}$ & $\mathrm{Cl}$ & $\mathrm{H}$ & $\mathrm{H}$ & $\mathrm{H}$ & $\mathrm{OH}$ & [61] \\
\hline Tyrosine Ochratoxin A & OTA-Tyrosine & 419 & Tyrosine & $\mathrm{Cl}$ & $\mathrm{H}$ & $\mathrm{H}$ & $\mathrm{H}$ & $\mathrm{OH}$ & [62] \\
\hline
\end{tabular}


The most recently discovered ones include a decarboxylated hydroquinone derivative, DC-OTHQ (often linked to glutathione) [43,63-65].

During coffee roasting (at $\left.225^{\circ} \mathrm{C}\right), 2^{\prime}$-DC-OTA and $2^{\prime} R$-OTA, two products of thermal degradation of OTA, were identified [66]. Ochratoxin $\alpha$ amide, which is formed at high temperatures during coffee roasting, was discovered. This represents another product of thermal degradation of OTA [67].

\section{OTA Analysis}

Principal methods developed for OTA determination in biological materials are summarized in Table 4.

In fact, more sensitive analytical methods or new methods for determining OTA and ochratoxins in biological materials are being developed consecutively toward the sophisticated development of instrumentation and analytical techniques but also toward the improvement of laboratory analytical methods. The most used and traditional analytical techniques include thin-layer chromatography, HPLC, and ELISA. Therefore, in the present article, the analytical techniques are divided into traditional ones, and the others. 
Table 4. Analytical methods for determination of OTA in food, feed, and biological materials.

\begin{tabular}{|c|c|c|c|c|}
\hline Method & Year & Biological Material & Limit of Detection (LOD) & References \\
\hline TLC & 1973 & barley & $12 \mathrm{ng} / \mathrm{g}$ & [68] \\
\hline TLC & 1973 & other commodities & $3-5 \mathrm{ng} / \mathrm{g}$ & [69] \\
\hline spectrophotometry & 1976 & barley, pigs kidney, human blood (confirmation by carboxypeptidase A) & $1-4 \mathrm{ng} / \mathrm{g}$ & [70] \\
\hline HPLC-UVD & 1979 & cereals & $1-5 \mathrm{ng} / \mathrm{g}$ & [71] \\
\hline HPLC-FLD & 1980 & food and feed & $5 \mathrm{ng} / \mathrm{g}$ & [72] \\
\hline HPLC-FLD & 1980 & (confirmation by boron trifuoride methanol) & & [73] \\
\hline HPLC-FLD & 1981 & feed & $1 \mathrm{ng} / \mathrm{g}$ & [74] \\
\hline RIA & 1975 & - & $20 \mathrm{ng} / \mathrm{g}$ & [75] \\
\hline ELISA & 1981 & food, feed, biological fluids & $25 \mathrm{pg} /$ assay & [76] \\
\hline LC-MS & 1987 & barley & $0.5 \mathrm{ng} / \mathrm{g}$ & [77] \\
\hline ion-pair HPLC & 1991 & human plasma & $0.02 \mathrm{ng} / \mathrm{mL}$ & [78] \\
\hline GC-MS & 1992 & food & $<0.1 \mathrm{ng} / \mathrm{g}$ & [79] \\
\hline HPLC-FLD & 1992 & corn, barley, kidney & 0.2 & [80] \\
\hline ELISA & 1993 & human sera & $10 \mathrm{pg} / \mathrm{mL}$ & [81] \\
\hline IAC coupled with Fluorometer & 1997 & liquid food matrices & $\mathrm{pg} / \mathrm{mL}$ & [82] \\
\hline LC-ESI-MS/MS & 1998 & food (coffee) & $20 \mathrm{pg} / \mathrm{on}$ column & [83] \\
\hline LC-ESI-MS/MS & 1999 & pig kidney, rye flour & $0.02 \mathrm{ng} / \mathrm{g}$ & [84] \\
\hline HPLC-FLD Confirmation carboxypeptidase & 2003 & Blood, urine & $0.1 \mathrm{ng} / \mathrm{mL}$ (blood); $4 \mathrm{ng} / \mathrm{mL}$ (urine) & [85] \\
\hline $\begin{array}{l}\text { HPLC-FLD Confirmations with } \\
\text { carboxypeptidase + LC-MS/MS }\end{array}$ & 2004 & Breakfast cereal & $0.05 \mathrm{ng} / \mathrm{g}$ & [86] \\
\hline PFIA & 2004 & barley & $3 \mathrm{ng} / \mathrm{mL}$ & [87] \\
\hline DNA aptamer & 2008 & wheat & $2 \mathrm{ng} / \mathrm{g}$ & [88] \\
\hline LC-MS/MS & 2010 & urine & $0.001-0.045 \mathrm{ng} / \mathrm{mL}$ & [89] \\
\hline ICP-MS & 2010 & wine & $0.003 \mathrm{ng} / \mathrm{mL}$ & [90] \\
\hline LC-MS/MS & 2012 & urine & OTA: $0.03 \mathrm{ng} / \mathrm{mL}$ & [91] \\
\hline flow electrochemical aptasensor with aptamer & 2013 & beer & $0.05 \mathrm{ng} / \mathrm{mL}$ & [92] \\
\hline UHPLC-FLR (LC-ESI-MS/MS) & 2014 & ginger & OTA: $0.1 \mathrm{ng} / \mathrm{g} ;(0.005-0.2 \mathrm{ng} / \mathrm{g})$ & [93] \\
\hline LC-MS/MS & 2015 & dried blood spots & $0.2 \mathrm{pg} /$ on column & [94] \\
\hline ELISA & 2012 & - & $1.2 \mathrm{ng} / \mathrm{g}$ & [95] \\
\hline Metal enhanced fluorescence & 2014 & Food/drinks (milk, juice) & $0.5 \mu \mathrm{g} / \mathrm{kg}$ & [96] \\
\hline Electroluminescence/Biosensor & 2015 & corn & $0.02 \mathrm{pg} / \mathrm{mL}$ & [97] \\
\hline Molecular imprinting & 2015 & Beer/wine & $1.7 \mu \mathrm{g} / \mathrm{L}$ & [98] \\
\hline PCR & 2015 & wine & $19 \mathrm{nM}$ & [99] \\
\hline
\end{tabular}

LC-ESI-MS/MS: Column liquid chromatography-electrospray ionization-tandem mass spectrometry; PFIA: Fluorescence polarization immunoassay; aptamers: Artificial short single stranded oligonucleotides, either DNA or RNA; PCR: Polymer chain reaction. 
Generally, all chemical methods for the analysis of OTA consist of several steps (extraction, clean-up, separation, detection, quantification, and confirmation of identity) [100]. Conventional sample extraction and clean-up are usually achieved by liquid extraction for OTA determination in kidneys of swine [101]. More recently, solid-phase extractions (SPE) notably for OTA determination in animal feed [102] and immunoaffinity columns (IAC) [103,104] (/homemade of IAC/; immunoaffinity cartridges commercially available) have become popular [105]. At present, different kinds of cartridges are commercially available for clean-up and pre-concentration, including IAC and molecular imprinted polymers (MIPs) cartridges, composed by anti-OTA antibodies and three-dimensional network specific for the target molecule. In this case, OTA passed through cartridges (e.g., Mycosep ${ }^{\mathrm{TM}}$ or Mycospin ${ }^{\mathrm{TM}}$ ) [106]. It is based on adsorption and the ion-exchange process [107]. The use of immunoaffinity chromatography in the clean-up step improves mycotoxin analysis and has a number of advantages: clean extracts, precision and accuracy, rapidity, and reduction of the use of dangerous solvents [82]. The main advantages of these columns are the specific binding of OTA onto the antibody and the near-complete removal of matrix interference [108]. Nevertheless, in the case of OTA, underestimation can be observed if extraction is done in an alkaline condition, because OTA is converted into open-ring OTA (OP-OA) and no longer recognized by antibodies [109-112].

The confirmation of OTA presence in biological materials is very important in order to guarantee quality of analytical results. Hult and Gatenbeck (1976) presented the OTA confirmation with carboxypeptidase A [70], as did Hunt et al. (1980) with boron trifuoride methanol [73] and Studer-Rohr et al. (1995) with diazomethane [113]. Quality assurance of analytical results (a laboratory accreditation, participation in proficiency testing, and the use of certified reference materials) according to the past norm EN 45001 (1989) [114] and the recent norm which is in force EN ISO/IEC 17025 (2005) [115] is very important for the purposes of OTA determination in biological materials.

Many analytical methods for the determination of OTA have been developed over time [100], and most of them involve the use of thin-layer chromatography (TLC) $[68,69]$ and, predominantly, high-performance liquid chromatography (HPLC) with fluorescence detection (FLD) [72]. Subsequently, OTA is identified and detected by LC-MS [77], LC-MS/MS [83,84], aptamers [88,92,116], ELISA [76,117], and immunosensing methods [118]. However, the technique most commonly used is based on liquid chromatography (LC) coupled with a fluorometric detector for highly sensitive detection signal [106]. It is known that, due to natural OTA fluorescence, OTA is generally determined by chromatographic techniques [119,120].

The other methods for the OTA determination used include gas chromatography-mass spectrometry (GC-MS) [79,113], fluorometric kits (the immunoaffinity columns coupled with a fluorometer) [82,87], fluorescence polarization immunoassay (PFIA) [87], isotope dilution [121], and a radioimmunoassay (RIA) [75,122-126]; however, due to health hazards of radiolabeled compounds and specialized waste disposal, RIA has not been in use for a long time [127]. More recent methods for OTA determination are inductively coupled plasma mass spectrometry ICP-MS [90], and capillary electrophoresis techniques [128]: capillary electrophoresis with laser-induced fluorescence detection (CE-LIF) [129,130], micellar electrokinetic capillary chromatography/MEKC/ [131], molecular imprint polymers (MIPs) [132-134], biosensors [133,135,136], and aptamers (single-stranded oligonucleotides (DNA or RNA) selected in vitro to bind with high affinity and specificity to molecular targets) $[88,92]$. The applications of aptamers are known and developed, e.g., in chromatography, capillary electrophoresis, mass spectrometry, and biosensors [137,138].

\section{Occurrence of OTA in Food and Feed}

In 1969, Shotwell et al. [139] with colleagues from the U.S. Department of Agriculture (USDA) published the very first piece of information about the amount of OTA in a maize sample at levels from 110 to $150 \mathrm{ng} / \mathrm{g}$. In 1970, Scott et al. [140] from Health Canada published data on OTA in moldy cereals, beans, and peanuts. OTA concentrations in wheat, oats, barley, and rye (62.0\% positive samples) ranged from 30 to $27.000 \mathrm{ng} / \mathrm{g}[140,141]$. The occurrence of OTA in pig kidney was first mentioned by 
Hald and Krogh in 1972 [142] and by Hunt et al. in 1979 [143]. Since that time, more than 90 kinds of foodstuffs of both plant and animal origins, including milk, have been found to contribute to the OTA dietary exposure [33].

As for foodstuffs of plant origin, OTA occurs in cereal products, olives, beans, beer, wine, coffee, cocoa products, raisins, figs, licorice, pulses, pumpkin seeds, and tea. In general, the average concentration of OTA is reported to range from 0.1 to $100 \mathrm{ng} / \mathrm{g}$. OTA concentration in black pepper, cayenne pepper, caraway, cardamom, coriander, chili powder, curcuma, and dried red pepper ranges from 1 to $100 \mathrm{ng} / \mathrm{g}$. Feedstuffs of plant origin — those made of wheat, oats, barley, rye, maize, rice, millet, sorghum, soybean, horse bean, peas, bean, broad bean, alfalfa, sunflower or pumpkin seeds, coconut, peanut cake, and hay/silage-also contain from 1 to $100 \mathrm{ng} / \mathrm{g}$ of OTA [144-146].

In foodstuffs of animal origin, e.g., in pork blood products, edible offal, pork meat, chicken meat and offal, and dry-cured ham, the levels of OTA range from 0.1 to $1 \mathrm{ng} / \mathrm{g}$. The same amounts are measured in feedstuffs of animal origin, e.g., in pork kidney and liver, pork meat, chicken liver, and viscera, and in mechanically separated chicken used as ingredients in pet food for cats and dogs $[144,145,147]$.

Tables 5-7 summarize the recent data related to OTA in foodstuffs obtained from the EU Rapid Alert System for Food and Feed (RASFF) [146]. The RASFF dealt with OTA in 175 cases in 2000-2015.

Table 5. OTA and alert notifications in the EU.

\begin{tabular}{lccc}
\hline Date of Case & Country & Foodstuffs & OTA (ng/g) \\
\hline $16 / 01 / 2015$ & Finland & Pumpkin seeds from China & 19 \\
$22 / 01 / 2015$ & Germany & Dried figs from Spain & 124 \\
$03 / 03 / 2015$ & Belgium & Wheat from Canada & 17 \\
$13 / 03 / 2015$ & Netherlands & Pumpkin seeds from China & 29 \\
$13 / 03 / 2015$ & France & Dried figs from Spain & 183 \\
$24 / 03 / 2015$ & France & Wheat from Canada & 18 \\
$27 / 03 / 2015$ & Switzerland & Ground mace from Sri Lanka & 42.5 \\
$12 / 05 / 2015$ & France & Buckwheat flour from France & 40 \\
$04 / 06 / 2015$ & Ireland & Liquorice root from Turkey & 433.5 \\
$10 / 06 / 2015$ & Poland & Raisins from Turkey & 19.3 \\
$15 / 07 / 2015$ & Slovak Republic & Raisins from Chile & 11.8 \\
$10 / 08 / 2015$ & France & Rye flour from France & 12.9 \\
$12 / 08 / 2015$ & Finland & Pumpkin seeds from China & 20000 \\
$13 / 08 / 2015$ & Luxembourg & Dried red chili peppers from Thailand & 30.8 \\
$01 / 09 / 2015$ & Romania & Sultanas from Turkey & 15.6 \\
$02 / 09 / 2015$ & Belgium & Rye malt from France & 13.8 \\
$02 / 09 / 2015$ & Belgium & Rye malt from France & 25.7 \\
$02 / 09 / 2015$ & Belgium & Rye malt from France & 38.6 \\
$25 / 09 / 2015$ & Croatia & Black pepper from Vietnam & 155 \\
$21 / 10 / 2015$ & Malta & Soft oaty bars from Switzerland & 1.4 \\
$02 / 12 / 2015$ & Belgium & Dried figs from Turkey & 14.4 \\
$08 / 12 / 2015$ & Latvia & Chili from China & 40 \\
$11 / 12 / 2015$ & Cyprus & Dried sultana raisins from Greece & 18.5 \\
$23 / 12 / 2015$ & Belgium & Dried figs from Turkey & 27.8 \\
\hline
\end{tabular}

Alert notifications are sent whenever a foodstuff presenting a serious health risk to humans is identified at the internal market and whenever the rapid action of the competent authorities is required. 
Table 6. OTA and border rejections.

\begin{tabular}{lccc}
\hline Date of Case & Country & Foodstuffs & OTA (ng/g) \\
\hline $22 / 01 / 2015$ & Poland & Raisins from Uzbekistan & 21.1 \\
$26 / 01 / 2015$ & Netherlands & Dried figs from Turkey & 24 \\
$11 / 02 / 2015$ & Germany & Raisins from Afghanistan & 11.8 \\
$19 / 02 / 2015$ & Latvia & Raisins from Afghanistan & 61 \\
$26 / 02 / 2015$ & Germany & Dried figs from Turkey & 17.4 \\
$13 / 03 / 2015$ & Hungary & Raisins from Uzbekistan & 24.3 \\
$30 / 06 / 2015$ & Croatia & Mixed spices from Kuwait & 45 \\
$21 / 07 / 2015$ & United Kingdom & Red pepper powder from Ethiopia & 92.5 \\
$13 / 08 / 2015$ & The Netherlands & Pistachios from the United States & 74 \\
$31 / 08 / 2015$ & Germany & Berbere spice mix from Ethiopia & 85.3 \\
$07 / 09 / 2015$ & The Netherlands & Red chili powder from India & 69 \\
$28 / 10 / 2015$ & Poland & Red chili powder from India & 32.6 \\
$16 / 12 / 2015$ & Germany & Red pepper spice mix from Ethiopia & 69.9 \\
\hline
\end{tabular}

Border rejections concern food and feed consignments that have been tested and rejected at the external borders of the EU.

Table 7. OTA and the EU Rapid Alert System for Food and Feed (RASFF) information.

\begin{tabular}{cccc}
\hline Date of Case & Country & Foodstuffs & OTA (ng/g) \\
\hline $13 / 01 / 2015$ & Germany & Dried figs from Turkey & 69.9 \\
$16 / 01 / 2015$ & Germany & Dried figs from Turkey & 45 \\
$16 / 02 / 2015$ & Germany & Sun dried figs from Turkey & 86 \\
$17 / 02 / 2015$ & Germany & Dried figs from Turkey & 32 \\
$02 / 06 / 2015$ & Germany & Spice mix and paprika from Ethiopia & 139 \\
$24 / 07 / 2015$ & Denmark & Organic raisins from Australia & 28 \\
$23 / 12 / 2015$ & Germany & Dried figs from Turkey & 10.8 \\
\hline \multicolumn{2}{l}{ Food that is only present in the notifying EU Member State is worth noting. }
\end{tabular}

\section{OTA Toxicity}

\subsection{OTA Nephrotoxicity}

OTA has been found to cause porcine and poultry nephropathy. OTA is implicated in the pathogenesis of some renal diseases including Balkan endemic nephropathy (BEN), kidney tumors occurring in certain endemic regions of the Balkan Peninsula [14,148], and chronic interstitial nephropathy (CIN) occurring in Tunisia [149,150] and other North African countries [151].

Kidney lesions have been observed on proximal tubules. The epithelial cells were damaged, for example, membrane integrity was lost, and the size and the density of the brush border were reduced. The chromatin was condensed, and the nuclear envelope disappeared. The histologic picture shows an enlargement of tubular membrane and an apparition of collagen fibers [152].

At the beginning, the BEN disease is characterized by a modification to epithelial cells without any change in the size of the organ. After chronic exposure, kidneys are reduced and interstitial fibrosis is the most important picture. At the end stage, impairment of renal function leads to enzymuria (e.g., gamma glutamyl transferase, alkaline phosphatase, lactate dehydrogenase) [153], polyuria accompanied with red tongue, thirst, and bitter taste [153]. Neither edema nor hypertension can be observed. Other symptoms such as headaches, lumbar pain, asthenia, and anemia (iron deficiency) were recorded. Several biochemical parameters changed including glycosuria, proteinuria (0.15-0.5 g/ $24 \mathrm{~h}$ ), alkalinization of urine, elevated serum creatinine, and an increase in immunoglobulin M (IgM) and immunoglobulin E (IgE) [154,155].

Data on OTA nephrotoxicity are summarized in Table 8. 
Table 8. Nephrotoxicity of OTA.

\begin{tabular}{|c|c|c|}
\hline Year & Nephrotoxicity Testing & References \\
\hline 1972 & $\begin{array}{l}\text { Balkan endemic nephropathy (BEN) has been suggested to be the result of fungal poisoning. The role of OTA in mycotoxicosis-BEN in } \\
\text { humans and porcine nephropathy. }\end{array}$ & [156] \\
\hline 1972 & $\begin{array}{l}\text { In view of the similarities between BEN and OTA induced porcine nephropathy, it has been suggested that OTA may be involved in the } \\
\text { etiology of BEN. }\end{array}$ & [157] \\
\hline 1978 & OTA is potentially nephrotoxic in all species tested with the exception of adult ruminants. & [158] \\
\hline 1987 & $\begin{array}{l}\text { Findings of higher OTA levels in the serum of patients suffering from BEN, which is a subtype of tubulointerstitial nephritis, led to } \\
\text { hypotheses about the association between the nephrotoxicity of OTA and the BEN and also the incidence of renal system tumors in the } \\
\text { population of these Balkan regions. }\end{array}$ & [159] \\
\hline 1991 & Nephropathy is primarily related to the mobilization of intracellular calcium. & [160] \\
\hline 1992 & $\begin{array}{l}\text { In terms of human pathologies, OTA is suspected to be the main etiological agent responsible for BEN and associated urinary tract tumors } \\
\text { (UTT) in humans. }\end{array}$ & {$[161]$} \\
\hline 1993 & $\begin{array}{l}\text { Experimental studies on the nephrotoxicity of OTA both in vitro and in vivo have shown that OTA disturbs the intracellular metabolic } \\
\text { processes (with subsequent apoptosis of the renal cells), renal hemodynamics, and-significantly and perhaps preponderantly-the } \\
\text { functions of the proximal tubules (even after subchronic exposition). OTA causes the decrease of glomerular filtration and tubular } \\
\text { resorption and affects all parts of the nephron and kidneys in toto. }\end{array}$ & [162-168] \\
\hline 1993 & A case of acute nephrotoxicity in humans. & {$[169,170]$} \\
\hline 1999 & OTA induces apoptosis in cultured human proximal tubule cells. & [171] \\
\hline 2002-2005 & The kidney is the main target of OTA toxicity in all animal species tested. & {$[14,172]$} \\
\hline 2002-2005 & $\begin{array}{l}\text { OTA has been also implicated in the etiology of BEN, a chronic degenerative kidney disease, in kidney tumors in humans in certain regions } \\
\text { of the Balkan Peninsula, and in chronic interstitial nephropathy (CIN) in Tunisia and other North African countries. }\end{array}$ & {$[14,148,150]$} \\
\hline 2005 & $\begin{array}{l}\text { Exposure to low OTA doses is responsible for nephrotoxicity; at nanomolar concentrations, OTA leads to specific changes of function and } \\
\text { phenotype in renal cells. }\end{array}$ & [173] \\
\hline 2007-2010 & $\begin{array}{l}\text { Very low OTA concentrations administered for a prolonged time (up to } 14 \text { days) influence the cellular fate (cellular hypertrophy) in human } \\
\text { proximal tubule; furthermore, they act not only in the target organ, e.g., in the kidney, but also in as yet unsuspected cells, such as } \\
\text { fibroblasts; the same damage will likely occur in chronic exposure. }\end{array}$ & {$[174,175]$} \\
\hline 2013 & Nephrotoxicity is a consequence of acute, sub-acute, and also chronic exposure to OTA. & [9] \\
\hline 2014 & $\begin{array}{l}\text { OTA inhibits the nuclear factor, erythroid 2-like } 2 \text { (Nrf2) oxidative stress response pathway. Nrf2 overexpression confers a survival } \\
\text { advantage and is often associated with cancer cell survival. }\end{array}$ & [176] \\
\hline 2015 & Dietary exposure to OTA represents a serious health issue including, e.g., human endemic nephropathies. & [50] \\
\hline
\end{tabular}




\subsection{OTA Carcinogenicity}

Data on OTA carcinogenicity are summarized in Table 9.

Table 9. OTA carcinogenicity and genotoxicity.

\begin{tabular}{|c|c|c|}
\hline Year & Nephrotoxicity testing & References \\
\hline 1978 & OTA induces renal and hepatic tumors in mice. & [177] \\
\hline 1984 & OTA is carcinogenic for mice. & [178] \\
\hline 1984 & CIT increases OTA carcinogenicity. & [179] \\
\hline 1987 & OTA carcinogenicity to humans: OTA classified in Group 3 (not classifiable as to its carcinogenicity to humans). & [180] \\
\hline 1989 & Male rats are more susceptible to renal tumors than female rats (NTP study). & [181] \\
\hline 1989 & The genotoxicity of ochratoxin A is reviewed. & {$[35,182]$} \\
\hline 1991 & OTA-DNA adducts: For the first time, OTA-DNA adducts are found in the kidney, liver, and spleen of mice. & [183] \\
\hline 1993 & OTA is re-classified as a possibly carcinogenic to humans based on a great amount of evidence of carcinogenity in several animal studies of $2 \mathrm{~B}$ in 1993. & [11] \\
\hline 1993 & $\begin{array}{l}\text { OTA-DNA adducts: Other studies take place in mice and rat tissues after acute and subchronic exposure, and in urinary tract tumors (UTT) of } \\
\text { Bulgarian subjects. }\end{array}$ & [184-186] \\
\hline 1993-2009 & $\begin{array}{l}\text { OTA-DNA adducts are also detected in tissues of humans presumably exposed to OTA in several countries (Bulgaria, Serbia, Croatia, Germany, Belgium, } \\
\text { France, Tunisia). }\end{array}$ & {$[16,17,185,187-190]$} \\
\hline 1998-2002 & $\begin{array}{l}\text { DNA adduction following chronic exposure (carcinogenic study) of rats to OTA first described; sex differences and dual mechanism—oxidative } \\
\text { pathways and DNA adduction—are observed }\end{array}$ & {$[12,13,191]$} \\
\hline 1998 & OTA-DNA adducts are observed in mother and progeny of mice fed OTA nine months after birth male mice develop cancer. & [192] \\
\hline 2000-2001 & In vitro formation of dG-OTA adduct. & {$[193,194]$} \\
\hline 2001-2002 & $\begin{array}{l}\text { Other studies with radiolabeled OTA were unable to detect any DNA binding of OTA, but explanation of this discrepancy is given in depth by } \\
\text { Pfohl-Leszkowicz and Castegnaro in } 2005 \text { [195] }\end{array}$ & {$[60,196]$} \\
\hline 2003 & OTA-DNA adduct in pigs subchronically exposed to low doses of OTA. Relation with biotransformation. & [197] \\
\hline 2002-2010 & OTA may be involved in testicular cancer. & {$[175,198-201]$} \\
\hline 2003-2008 & CIT increases genotoxicity of OTA and modifies the metabolism of rats exposed to low doses for three weeks. & {$[202,203]$} \\
\hline 2004 & Evidence for covalent DNA adduction by OTA following chronic exposure to OTA in rats (and subacute exposure in pigs). & [190] \\
\hline 2004 & $\begin{array}{l}\text { Another research group, using the highly sensitive accelerator of the mass spectrometry technique, does not detect DNA adducts after the } \\
\text { administration of }{ }^{14} \text { C-labeled OTA to rats. }\end{array}$ & [204] \\
\hline 2004 & $\begin{array}{l}\text { In 2004, a review of the NTP experimental rat tumor data for OTA also places OTA in the category of "chemicals inducing renal tumors through direct } \\
\text { interaction of the parent compound or metabolite with renal DNA" based on histopathological evidence. }\end{array}$ & [205] \\
\hline
\end{tabular}


Table 9. Cont

\begin{tabular}{|c|c|c|}
\hline Year & Nephrotoxicity testing & References \\
\hline $2004-2010$ & The long-term OTA studies confirm the incidence of tumors in rats; in male rats, these tumors are related to OTA dose & [205-207] \\
\hline 2004-2012 & $\begin{array}{l}\text { OTA is a direct genotoxic forming covalent DNA adducts in the kidney OTA can indeed react with DNA via a phenolic radical resulting in } \\
\text { C8-deoxyguanosine adduct (synthetized and chemical identified by mass spectrum). }\end{array}$ & {$[175,190,201,207-209]$} \\
\hline 2006 & Confirmation of OTA genotoxicity via measurement of comet in rat kidneys. & [210] \\
\hline 2007 & Chronic exposure to low OTA doses can be much more damaging than acute exposure to a high dose. & [16] \\
\hline 2007 & DNA diploidy in rat tumors is associated to genetic damage. & [211] \\
\hline 2007 & OTA induces an increase of mutation at two loci-hypoxantine-guanine phophoribosyl transferase (HPRT) and thymidine kinase (TK). & [212] \\
\hline 2008 & DNA adduct cannot be confirmed, but the explanation is given by Pfohl-Leszkowicz et al. (2009) [64] & [213] \\
\hline 2008 & Correlation between biotransformation of OTA and direct covalent binding on DNA. & [214] \\
\hline 2009 & $\begin{array}{l}\text { It is found that the kidney DNA adduct pattern of BEN patients is similar to the kidney DNA adduct pattern of pigs living in the same farm and pigs } \\
\text { co-exposed to OTA, fumonisins, and citrinin. }\end{array}$ & [17] \\
\hline 2009 & A different proposal of mechanism for OTA-mediated renal carcinogenesis and threshold model for its risk assessment. & [215] \\
\hline 2009-2010 & Identification by LC-MS/MS of these DNA adduct in rat tissues. & {$[64,201]$} \\
\hline 2010 & OTA is carcinogenic for poultry. & [216] \\
\hline 2011 & Induction of mutation only in medulla of rat kidney exposed to carcinogenic dose. & [217] \\
\hline 2012 & $\begin{array}{l}\text { Relation structure activity studies clearly indicate that OTHQ (ochratoxin hydroxyquinone) is responsible of direct genotoxicity, whereas some others } \\
\text { are cytotoxic. }\end{array}$ & {$[65,209]$} \\
\hline \multirow[t]{2}{*}{2012} & OTA is activated to a species that is a directly genotoxic mutagen. OTHQ in presence of cysteine is also mutagenic. & [218] \\
\hline & A new approach to cancer represents miRNA. & {$[219,220]$} \\
\hline 2013 & $\begin{array}{l}\text { The induction of miR-132 and miR-200c by OTA elevates reactive oxygen species (ROS) levels and profibrotic (profibrotic transforming growth factors } \beta \text {, } \\
\text { TGF } \beta \text { ) expression. }\end{array}$ & [221] \\
\hline 2014 & $\begin{array}{l}\text { OTA has the potential to initiate or support the development of fibrotic kidney diseases by involving post-transcriptional regulation mechanisms } \\
\text { comprising miR-29b. OTA reduces the impact of miR-29b and thus enhances collagen protein expression. }\end{array}$ & [222] \\
\hline 2014 & A low dose of OTA induces micronuclei, and OTA delays the DNA repair kinetics. & [223] \\
\hline 2014 & OTA increases proliferating cell nuclear antigen after 13 weeks in kidney and kidney damages. Limited oxidative stress. & [224] \\
\hline 2015 & Dietary exposure to OTA represents a serious health issue, including urinary tract tumors in humans. & [50] \\
\hline
\end{tabular}


In 1976 and 1983, IARC first evaluated the carcinogenic risk that OTA poses toHuman. No report on cases of cancer or epidemiological studies were available at that time and, in the absence of adequate epidemiological data, no evaluation of the carcinogenicity of OTA with respect to Humans could have been made [225,226]. In 1987, the IARC reclassified OTA into Group 3 (not classifiable for its carcinogenicity to humans). Based on a great amount of evidence of OTA carcinogenicity revealed in new animal studies, it was again reclassified into Group 2B (possibly carcinogenic to humans) in 1993. At present, new information regarding genotoxicity of OTA (formation of OTA-DNA adducts), its role in oxidative stress, and the identification of epigenetic factors involved in OTA carcinogenesis-should they indeed provide strong evidence that OTA carcinogenicity is mediated by a mechanism that also occurs in humans - could lead to another reclassification of OTA. In the light of recently available data, it does not seem inappropriate to upgrade its carcinogenicity from Group 2B (possibly carcinogenic to humans) to at least Group 2A (probably carcinogenic to humans) [227] or, in our opinion, even to Group 1 (carcinogenic to humans).

\section{OTA Biomarkers}

Biomonitoring of OTA provides the best approach to assess the human exposure to OTA from any source and through any route [228]. The first studies reporting the presence of OTA in human blood were carried out in the Balkans in the 1970s [229]. The exposure of the human population to OTA and other ochratoxins represents a worldwide problem. Baldwin et al. (2011) reviewed biomarker researches for the most important mycotoxins and defined biomarkers [230]. Recently, a biomarker of exposure has been defined to be a biological measure which is correlated with the quantity of the xenobiotic ingested; resulting in the improved exposure classification in comparison with more traditional approaches [231]. OTA in milk (non-invasive sampling), OTA in blood serum (invasive sampling), OTA in urine (non-invasive sampling), and OTA in human kidneys (sampling post-mortem or after nephroctomia) are qualified as biomarker of exposure to OTA [232]. Soto et al. (2015) have recently used several biomarkers for evaluating the OTA exposure. The values of OTA detected in potential biomarkers of exposure for blood, breast milk, and urine ranged from 0.15 to 18.0 , from 0.002 to 13.1 , and from 0.013 to $0.2 \mathrm{ng} / \mathrm{mL}$, respectively. The calculated EDI for OTA in plasma ranged from 0.15 to $26 \mathrm{ng} / \mathrm{kg}$ bw / day and has turned out to be higher than that obtained in urine $(0.017$ to $0.4 \mathrm{ng} / \mathrm{kg}$ bw/day). All these values have been correlated with the range of EDI for OTA calculated from food products: 0.0001-25.2 $\mathrm{ng} / \mathrm{kg}$ bw/day [233].

\subsection{OTA in Human Blood}

In 1979, OTA determination in human whole blood and serum was developed [234]. In the past several decades, OTA has been detected in human blood samples on a worldwide scale. Scott (2005) has described OTA in blood serum as a uniquely useful biomarker of OTA exposure due to its high-affinity binding to serum albumin or to other small proteins, which should result in higher serum OTA levels and long persistence of OTA in blood serum [235]. OTA blood amounts will integrate exposure over longer periods [236]. The use of serum or plasma has been described as more suitable matrices in comparison to whole blood [105,237]. Generally, the determination of OTA in blood samples remains the basic method of how to monitor human exposure to OTA, which is ubiquitous in human blood serum/plasma and indicates continuous exposure to the toxin, originating mainly from food intake [235].

Table 10 describes some of the most notable findings of OTA in blood on a worldwide scale.

Advantages arising from monitoring OTA in the blood of healthy persons consist mainly in relatively high OTA levels found compared with OTA determinations in urine [232]. OTA blood determination will integrate exposure over longer periods, while biomarker analysis in urine apparently better reflects day-to-day variations in the exposure of adults and infants [231,236-240]. 
Table 10. An overview of chronologically published data on OTA in blood samples from healthy persons.

\begin{tabular}{|c|c|c|c|c|c|}
\hline Country & Collecting Period & $n+(\%)$ & OTA $\min -\max (\mu \mathrm{g} / \mathrm{L})$ & OTA Mean $(\mu \mathrm{g} / \mathrm{L})$ & Reference \\
\hline \multicolumn{6}{|l|}{ Europe } \\
\hline Former Yugoslavia & 1980 & 7.8 & $\max .8 .0$ & 5.4 & {$[229,241]$} \\
\hline Germany & 1977-1985 & 56.5 & $0.1-14.4$ & 0.6 & [242] \\
\hline Bulgaria & $1984,1986,1989-1990$ & 10 & - & 12.0 & {$[243,244]$} \\
\hline Poland & 1983-1985 & 7.2 & $1-40$ & 0.28 & [245] \\
\hline Former Yugoslavia & 1981-1989 & $0-3.7$ & $\max .50 .0$ & - & [246] \\
\hline Germany & 1988 & 68 & $0.1-8.4$ & 0.75 & [247] \\
\hline Sweden & 1989 & 12.8 & $0.3-7.0$ & 0.20 & [78] \\
\hline Czechoslovakia & 1990 & 21 & $0.5-12.0$ & 0.37 & [248] \\
\hline Denmark & 1990 & 54.2 & $0.1-13.2$ & 1.8 & [241] \\
\hline France & - & - & $0.1-6.0$ (rural); $0.1-1.3$ (urban) & - & [249] \\
\hline Czechoslovakia & 1990-1991 & 40 & $0.5-19.4$ & 0.63 & [250] \\
\hline France & 1991-1992 & 18.1 & $0.1-161$ & 0.4 & {$[251,252]$} \\
\hline Italy & 1992 & 100 & $0.1-2.0$ & 0.53 & [253] \\
\hline Switzerland & 1992-1993 & 100 & $0.06-6.02$ & ca. 0.4 & [105] \\
\hline Hungary & 1995 & 51 & $0.2-12.9$ & - & [254] \\
\hline Italy & 1994-1996 & 97 & $0.1-57.2$ & 0.56 & [255] \\
\hline Hungary & 1995 & 82 & $0.2-10.0$ & - & [256] \\
\hline Czech Republic & 1994-2002 & 94.2 & $0.1-13.7$ & 0.24 & [257-260] \\
\hline Spain & 1996-1998 & 53.3 & $0.5-4.0$ & 0.71 & {$[261]$} \\
\hline Spain & 1996-1997 & 72 & $0.21-6.96$ & 0.63 & [262] \\
\hline Hungary & 1997 & 77 & $0.1-1.4$ & - & [263] \\
\hline Croatia & 1997-1998 & 59.4 & $\max .15 .9$ & 0.30 & [264-266] \\
\hline Sweden & 1997 & 100 & $0.01-0.48$ & 0.21 & {$[145,267]$} \\
\hline Norway & 1998 & 100 & $0.05-0.42$ & 0.18 & {$[145,267]$} \\
\hline Germany & 1999 & 98.1 & $0.06-2.03$ & 0.27 & [268] \\
\hline UK & 2000 & 100 & $0.4-3.11$ & 1.09 & {$[145,269]$} \\
\hline Norway & - & - & $0.02-5.53$ & 0.40 & {$[270]$} \\
\hline Bulgaria & - & 100 & $\max .8 .4$ & 1.59 & [85] \\
\hline Portugal & 2001-2002 & 100 & $0.14-2.49$ & - & [271] \\
\hline Poland & 2005 & 100 & $0.1-0.4$ & 0.37 & [272] \\
\hline Germany & 2005-2006 & 100 & $0.05-0.75$ & 0.75 & [18] \\
\hline Czech Republic & 2005 & 83.7 & $0.1-2.3$ & 0.21 & [273] \\
\hline Spain & 2008 & 100 & $0.15-5.71$ & 1.09 & [274] \\
\hline Spain & 2008 & 98.6 & $0.11-8.68$ & 0.86 & [275] \\
\hline Germany & 2008 & 100 & $0.19-0.29$ & 0.25 & [276] \\
\hline Spain & - & 100 & $0.06-10.92$ & 0.8 & [277] \\
\hline
\end{tabular}


Table 10. Cont.

\begin{tabular}{|c|c|c|c|c|c|}
\hline Country & Collecting Period & $n+(\%)$ & OTA $\min -\max (\mu \mathrm{g} / \mathrm{L})$ & OTA Mean $(\mu \mathrm{g} / \mathrm{L})$ & Reference \\
\hline Italy & - & 99.1 & $0.03-2.92$ & 0.23 & [278] \\
\hline Czech Republic & 2012 & 96 & $0.1-0.35$ & 0.15 & [279] \\
\hline $\begin{array}{c}\text { Czech Republic } \\
\text { Africa }\end{array}$ & 2012 & - & $0.37-1.13$ & 0.17 & [280] \\
\hline \multicolumn{6}{|l|}{ Africa } \\
\hline \multirow{2}{*}{ Tunisia } & $\begin{array}{l}- \\
-\end{array}$ & $\begin{array}{c}66.9 \\
62\end{array}$ & $\begin{array}{l}\max .9 .0 \\
\max .3 .2\end{array}$ & $\begin{array}{l}2.8 \\
1.22\end{array}$ & {$[281]$} \\
\hline & - & 66 & max. 2.3 & $\begin{array}{c}1.22 \\
1.1\end{array}$ & {$[282]$} \\
\hline Egypt & - & 2.9 & $\max .0 .91$ & 0.08 & [151] \\
\hline Sierra Leone & 1996 & 33 & $\max .18 .2$ & - & [283] \\
\hline \multirow[t]{4}{*}{ Morocco } & 2000 & 60 & $0.08-6.59$ & 0.2 & [284] \\
\hline & 1991-2000 & $62-82$ & $0.1-5.5$ & 2.0 & [285] \\
\hline & 1996,1998 & 100 & $0.1-8.06$ & 0.53 & [150] \\
\hline & - & 71 & $\max .7 .5$ & 2.6 & [286] \\
\hline Ivory Coast & 2001, 2004 & 34.9 & $\max .11 .62$ & 0.58 & [287] \\
\hline Tunisia & - & 28 & $0.12-3.4$ & 0.49 & [288] \\
\hline Tunisia & - & 52.3 & $0.11-6.1$ & 0.77 & [289] \\
\hline Tunisia & 2007-2009 & 49 & $1.7-8.5$ & 3.3 & [290] \\
\hline $\begin{array}{c}\text { Tunisia } \\
\text { Asia }\end{array}$ & - & 34 & $0.12-1.5$ & 0.22 & [291] \\
\hline Japan & $1992-1996$ & 85 & $\max .0 .28$ & 0.07 & [292] \\
\hline Lebanon & 2001-2002 & 33 & $\max .1 .24$ & 0.31 & [293] \\
\hline Pakistan & - & 97 & $\max .1 .24$ & 0.31 & [294] \\
\hline Turkey & - & - & $\max .1 .43$ & 0.44 & [295] \\
\hline \multirow[t]{2}{*}{ Turkey } & 2008-winter & 76.7 & $0.03-0.89$ & 0.14 & \\
\hline & 2007-summer & 97.5 & $0.03-1.50$ & 0.31 & [296] \\
\hline Bangladesh & - & 100 & $0.2-6.63$ & 0.85 & [240] \\
\hline \multirow[t]{2}{*}{ Turkey } & -summer & 100 & $0.03-1.55$ & 0.31 & \\
\hline & -winter & 83.3 & $0.05-1.12$ & 0.5 & [297] \\
\hline \multicolumn{6}{|l|}{ The Americas } \\
\hline Canada & 1991 & 38.3 & max. 9.0 & 1.29 & [298] \\
\hline Canada & $1994^{*}$ & 100 & $\max .2 .37$ & 0.88 & [299] \\
\hline Chile & 2004 & 54 & $0.4-2.75$ & 0.44 & \\
\hline (2 regions) & & 91 & $0.4-2.12$ & 0.77 & [300] \\
\hline Costa Rica & - & 95 & max. 1.91 & 0.62 & [301] \\
\hline Argentina & 2004-2005 & 63.8 & $0.19-47.6$ & 0.15 & \\
\hline (2 regions) & & & $0.19-74.8$ & 0.43 & [302] \\
\hline
\end{tabular}

Abbreviations: $\mathrm{n}+(\%)$ : percentage of positive samples; *study included persons working at grain storage facilities; rural, urban (population). 


\subsection{OTA in Urine}

Urine is a major excretion route for both OTA and OT $\alpha$ (5-chloro-8-hydroxy-3methyl-1-oxo-3,4-dihydroisochromene-7-carboxylic acid; formula, see Table 3) in humans [45]. OTA can be found in urine several days after OTA ingestion [8]. The elimination of OTA through human urine has been reported to be low (mean value between 20 and $80 \mathrm{ng} /$ day) and independent of the dose ingested [237]. The OTA uptake has been described as dependent on the free OTA concentration, which is severely limited by the binding of OTA to serum albumin [8]. Thus, the relationship between OTA in urine and OTA intake remains a complex issue as in the case of OTA in blood.

The first study measuringing OTA in urine in Europe was conducted by Mac Donald et al. (2001) [270] in the UK. In this study, OTA was found in 46 urine samples (92\%) collected over $24 \mathrm{~h}$ from 50 volunteers (healthy individuals from the UK). OTA concentrations ranged from $<10$ to $58 \mathrm{ng} / \mathrm{L}$, and the mean value was about $21 \mathrm{ng} / \mathrm{L}$. This study demonstrated a strong correlation between OTA concentrations in urine and its dietary intake. The second study in Europe was conducted in Bulgaria by Castegnaro et al. (1991) [303]. A total of 152 urine samples collected from patients with BEN (Balkan endemic nephropathy) or urinary tract tumors (UTT) and from the control families were analyzed, and OTA was detected in about $33 \%$ of the samples of urine (more often in endemic villages than in nonendemic ones) in the range 5-604 $\mathrm{ng} / \mathrm{L}$ and in healthy people in the range 5-43 $\mathrm{ng} / \mathrm{L}$ $(\mathrm{LOQ}=5 \mathrm{ng} / \mathrm{L})$. In Europe, another one-month follow-up study of OTA in urine samples after a 24-h collection of urine from the inhabitants with BEN in Bulgaria (from 16 healthy volunteers from two villages located in the Vratza district with a high risk area for BEN; 5 of Gorno Pestehne, 11 of Beli Izvor) was conducted by Petkova-Bocharova et al. (2003) [85]. 98\% of samples were positive and contained OTA in the range 10-1910 ng/L. The OTA mean value in Gorno Pestehne was $50.8 \mathrm{ng} / \mathrm{L}$, and in Beli Izvor it was $168.6 \mathrm{ng} / \mathrm{L}$ [85]. In a Czech study carried out in 2010, OTA was measured in a total of 236 samples of urine collected from healthy persons within a 24-h cycle (males/females, 45-60 years old, two samples per person from non-consecutive days, with at least a 14-day time difference). A total of 185 samples $(78 \%)$ of these 236 samples were positive, with a limit of quantification (LOQ) of $2.0 \mathrm{ng} / \mathrm{L}$, a mean of $7.32 \mathrm{ng} / \mathrm{L}$, and a median of $4.47 \mathrm{ng} / \mathrm{L}[304,305]$. These data signalize the real exposure of the given population group to OTA, with a higher percentage of positive urine samples in men $(92 \%)$ than women $(65 \%)$ [305].

OTA was usually determined in morning urine (not 24-h urine) in these countries (see also Table 11). However, in exposure studies, it is recommended that urine is collected over $24 \mathrm{~h}$-representative of the excretion throughout a day [306].

The multibiomarker methods have been applied in several pilot studies to prove their applicability and to estimate mycotoxin exposure in the populations/individuals tested. The application of these methods resulted in advanced data on exposure patterns and revealed new findings on co-exposure to the mycotoxin combinations [307]. In addition, it must be mentioned that urinary excretion mainly reflects the recent mycotoxin intake, whereas measurements in plasma/serum are more likely to reflect the long-term exposure [307]. As a result of the advent of the latest generation of high-performance LC-MS/MS instruments, a clear trend toward the development and application of multianalyte methods in mycotoxin biomarker research can be observed [308]. Warth et al. (2012) injected samples directly into the LC-MS/MS system to facilitate the quantification of 15 analytes [308]. A method developed by Ediage et al. (2012) [91] covered seven mycotoxins and several important conjugation and breakdown products (for a total of 18 analytes). In this study, OTA, OT $\alpha$, and 4-OH OTA were measured in human volunteers [91]. However, none of the target metabolites of OTA such as OT $\alpha$ or 4-OH OTA were confirmed in another study performed with urine samples in Cameroon [309], but the data correlate with similar findings reported for a Korean population [89]. According to Munoz et al. (2010a) [276], interindividual variability in the detoxification of OTA in human urine may account for the observed variations in urinary OT $\alpha$, and the possibility cannot be excluded that a low rate of OTA detoxification is a characteristic of some human populations [309]. The highest concentration of OTA 
reported so far in human urine was detected in Sierra Leone with a range of 70-148,000 ng/L, but no mean was reported [310]. Table 11 summarizes the OTA detection in human morning urine around the world. Last but not least, in dietary studies carried out in Serbia, in addition to OTA, several OTA derivatives have been detected in urine (and in blood). A clear difference between men and women has been observed [17].

Table 11. The results of OTA in human morning urine from different populations.

\begin{tabular}{|c|c|c|c|c|}
\hline Country & $\mathbf{n}$ & $n+\%$ & Mean (ng/L) & Reference \\
\hline Croatia & 35 & 94 & 239.0 & [311] \\
\hline Hungary & 88 & 61 & 13.0 & [312] \\
\hline Portugal & 60 & 70 & 27.0 & [313] \\
\hline Portugal & 30 & 43 & 19.0 & [314] \\
\hline Portugal & 43 & 72.1 & 26.0 & [315] \\
\hline Croatia & 45 & 43 & 17.0 & [316] \\
\hline Croatia & 45 & 18 & 7.0 & [316] \\
\hline Portugal & 155 & 92 & 18.0 & [317] \\
\hline Turkey & 233 & 90 & $14.3^{*}$ & [318] \\
\hline Germany & 13 & 100 & 70.0 & [276] \\
\hline South Korea & 12 & 100 & 31.0 & [89] \\
\hline Spain & 72 & 12.5 & 237.0 & [319] \\
\hline Spain & 27 & no stated & - & [320] \\
\hline Italy & 10 & 100 & - & [321] \\
\hline Sri Lanka & 31 & 93.5 & $20.0^{* *}$ & [322] \\
\hline Portugal & 95 & 87.4 & 22.0 (winter) & [323] \\
\hline Portugal & 95 & 81.1 & 16.0 (summer) & [323] \\
\hline Croatia & 40 & 78.0 & 90.0 (before enzyme treatment) & [324] \\
\hline Croatia & 40 & 58.0 & 130.0 after enzyme treatment) & [324] \\
\hline Cameroon & 175 & 63 & 280.0 & [308] \\
\hline \multirow{2}{*}{ Cameroon } & 145: HIV positive & 17 & 80.0 & \multirow{2}{*}{ [325] } \\
\hline & 30: HIV: sero-negative & 10 & 60.0 & \\
\hline South Africa & 53 & 98 & 41.0 & [326] \\
\hline Cameroon & 220 & 32 & 200.0 & [309] \\
\hline Italy & 52 & 100 & 144.0 & [327] \\
\hline Chile & 39 & & $\begin{array}{c}30-433^{* * *} \\
30-124^{* * * *}\end{array}$ & [239] \\
\hline Portugal & 472 & 86.4 & $19.0^{* * * * *}$ & [328] \\
\hline Germany & 30 & 15 & 40.0 & [329] \\
\hline Haiti & 47 & 33 & 109.0 & [329] \\
\hline Bangladesh & 72 & 76 & 203.0 & [329] \\
\hline
\end{tabular}

Abbreviations: $\mathrm{n}$ : numbers of samples; $\mathrm{n}+\%$ : percentage of positive samples; ${ }^{*} \mathrm{ng} / \mathrm{g}$ creatinine; ${ }^{* *} \mathrm{GM}$ : geometric mean; ${ }^{* * *}$ range in newborns consuming colostrums; ${ }^{* * * *}$ range of samples collected between 4 and 6 months of infants' life; ${ }^{* * * * *}$ mean in $\mathrm{ng} / \mathrm{kg}$.

\subsection{OTA in Human Milk}

As OTA is also excreted via human milk, breastfed children including babies are exposed to OTA as well $[239,330]$. Nevertheless, OTA amounts in milk are reported to be much lower than concentrations of OTA in blood (down to 10 times) [331]. In Italy, OTA was detected in milk from healthy women with varying daily diets in different geographical regions [332]. The relationship between OTA contamination of human milk and its dietary intake was examined [333], and it was confirmed that OTA occurrence in human milk was likely associated with maternal dietary habits. The strongest associations were observed with foodstuffs of plant origin and, to a lesser extent, with foodstuffs of animal origin [333].

Table 12 summarizes data on OTA presence in human milk worldwide. 
Table 12. Data on OTA in human milk worldwide.

\begin{tabular}{|c|c|c|c|c|}
\hline Country & $\mathbf{n}$ & $n+(\%)$ & Range Positive Samples (ng/L) & References \\
\hline \multicolumn{5}{|c|}{ European countries } \\
\hline Germany & 36 & 11 & $17-30$ & [330] \\
\hline Italy & 50 & 18 & $1,200-6,600$ & [332] \\
\hline Sweden & 40 & 58 & $10-40$ & [331] \\
\hline Hungary & 92 & 41 & $200-7,200$ & [255] \\
\hline Switzerland & 40 & 10 & 5-14 & [105] \\
\hline Italy & 111 & 20 & $100-12,000$ & [334] \\
\hline Italy & 4 & 75 & $8-540$ & [335] \\
\hline Norway & 115 & 33 & $10-130$ & [336] \\
\hline Norway & 80 & 21 & 10-182 & [333] \\
\hline Italy & 231 & 86 & $10-57$ & [337] \\
\hline Poland & 13 & 38 & $6-17$ & [338] \\
\hline Italy & 82 & 74 & $5-405$ & [339] \\
\hline Slovakia & 76 & 30 & $2-60$ & [340] \\
\hline Italy & 57 & 78.9 & $1-75$ & [341] \\
\hline Germany & 90 & 60 & $10-100$ & [342] \\
\hline \multicolumn{5}{|c|}{ Africa } \\
\hline Sierra Leone & 113 & 35 & $200-337,000$ & [343] \\
\hline Egypt & 120 & 36 & $5,000-45,000$ & [344] \\
\hline Egypt & 50 & 72 & $1,890 \pm 980 *$ & [345] \\
\hline Australia & 100 & 2 & $3,000-3,600$ & [346] \\
\hline \multicolumn{5}{|c|}{ Asia } \\
\hline Turkey & 75 & 100 & $620-13,111$ & [347] \\
\hline Iran & 136 & 2.7 & $90-140$ & [348] \\
\hline Iran & 87 & 84 & $1.6-60$ & [349] \\
\hline \multicolumn{5}{|c|}{ The Americas } \\
\hline Brazil & 50 & 4 & $10-20$ & {$[350]$} \\
\hline Chile & 11 & 100 & $44-184$ & [351] \\
\hline Brazil & 224 & 0 & & [352] \\
\hline Chile & 50 & 80 & 10-186 & [239] \\
\hline Brazil & 100 & 66 & $0.3-21$ & [353] \\
\hline
\end{tabular}

In some countries, e.g., Egypt, Turkey, and Sierra Leone, OTA milk concentrations were found to be more than 100-fold higher in comparison with Europe (see Table 12). It can be concluded that, despite the fact OTA concentrations in milk compared with blood are much lower, OTA contamination of human breast milk presents a potentially serious health hazard [354].

\subsection{OTA in Human Kidneys}

OTA presence in human tissues seems to be direct and definite proof of human exposure to OTA, although practicability of such measurements "in vivo" is obviously limited [355]. Taking OTA's nephrotoxicity in mind, in particular, there are not many studies available that have attempted to determine OTA in human kidneys. Several studies have been carried on the content of OTA in human kidneys, e.g., in Germany [356], in the Czech Republic in 30 samples of kidney ( $40 \%$ positive/detectable/samples; OTA ranged from 0.1 to $0.2 \mathrm{ng} / \mathrm{g}$; mean $0.07 \mathrm{ng} / \mathrm{g}$; results of OTA $<0.1 \mathrm{ng} / \mathrm{g}$ (LOQ) given as $1 / 2$ limit of quantification $=0.05 \mathrm{ng} / \mathrm{g}$ ) [357], and in Poland in 19 samples of kidney (78.9\% positive/detectable; OTA ranged from 0.15 to $0.39 \mathrm{ng} / \mathrm{g}$ with mean $0.26 \mathrm{ng} / \mathrm{g}$ ) [268]. Several human kidneys samples (60) obtained from patients suffering from kidney (or urinary bladder) cancer from Bulgaria (8 samples) [186], Serbia (10 samples), Croatia (16 samples), and France $(18)[16,17]$ have been analyzed up to now. Not only was OTA detected but also OTA derivatives such as OTHQ, OTHQ-GSH, 4-OH OTA, and OTB. Interestingly, DNA adducts were detected, and the nature of the DNA was in relation to the OTA derivatives. In Croatia, the DNA adducts profile of a farmer was similar to the profile of the pigs and poultry from his farm. It has been 
observed that the exposure has been higher in rural regions, and co-exposure to CIT and/or FB has been systematic $[16,17]$.

\section{Regulation of OTA in Food and Feed}

Due to its toxic properties, OTA is subject to legal regulation both on national and international levels. The toxicity of OTA became more or less evident by the end of the 1970s. A real debate on whether OTA in food and feed shall be regulated on a national or international level does not seem to predate the 1990s. This circumstance contrasts with the case of other mycotoxins, in particular, the aflatoxins (in the USA, the first limits for aflatoxins were established as early as the 1960s; soon after their discovery [358], the European Communities followed in the 1970s) [359].

For OTA, in 1991, van Egmond estimated that in 60 countries where some legal regulations with respect to mycotoxins existed, only 11 set limits on OTA (Brazil, Czechoslovakia, Denmark, France, Greece, Hungary, Israel, The Netherlands, Romania, Sweden, and the United Kingdom) [360]. In 2003, when a worldwide survey on legal regulation of mycotoxins was conducted by the FAO in cooperation with the Dutch Foreign Service, the number of countries with legal limits on OTA in food and feed grew to 37 (compared to more than 76 countries with legal limits for aflatoxins) [359]. No such large-scale survey has been reported ever since [361]. However, it may be assumed that the number of countries where OTA presence in food and feed is subject to legal regulation is not lower now than it was in 2003 (see Figure 5). This assumption can be based on two major arguments. Firstly, since 2003, research has provided new data on OTA's harmful effects to human and animal health. Secondly, due to the globalization of food and feed markets, discussion on how to tackle the health hazards linked to OTA (and other mycotoxins) has intensified on an international level and has had repercussions back on the national level. By way of example, China seems to have recently established limits on OTA in both food and feed [362].

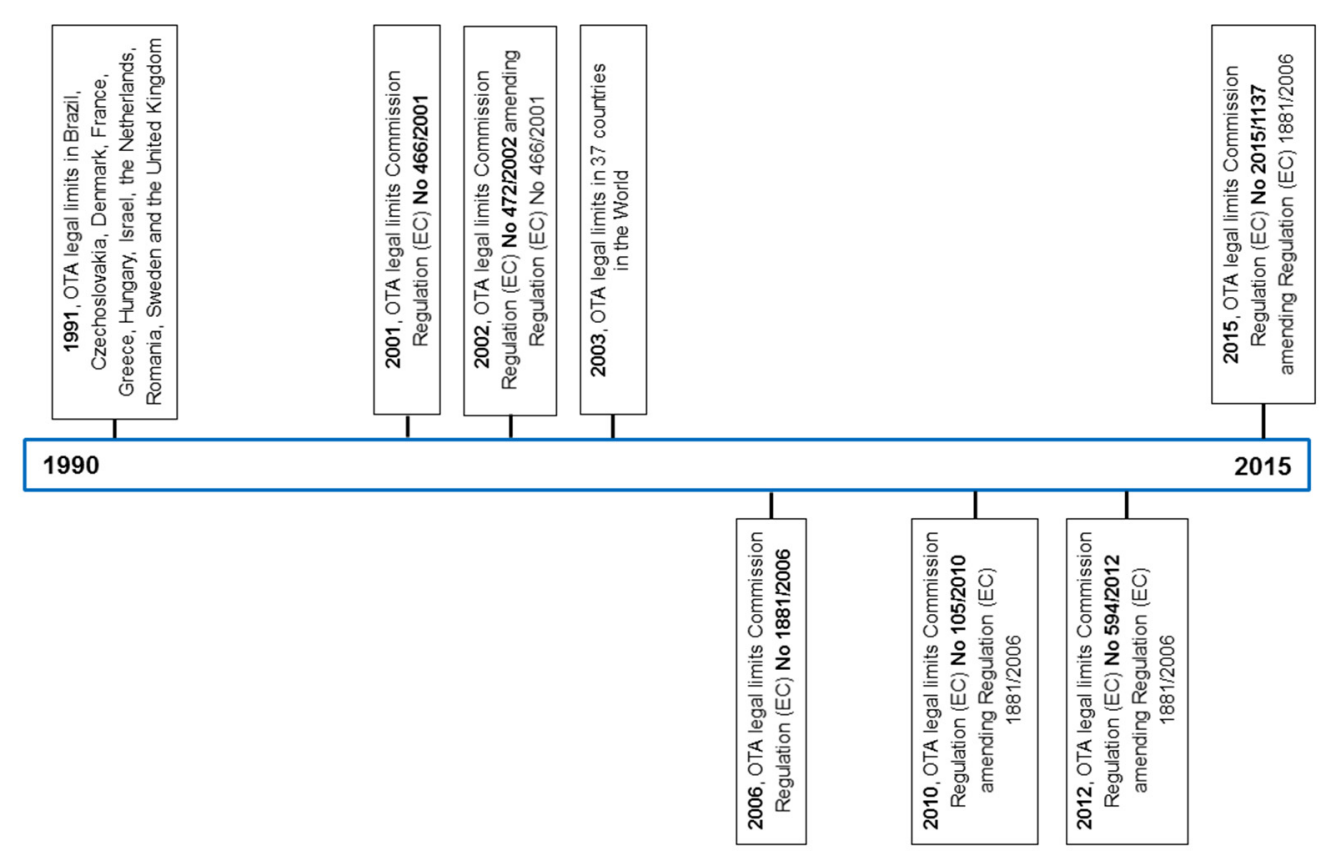

Figure 5. The milestones in evolution of legal regulation of OTA in years 1965-2015.

Membership of States in international or regional organizations may also contribute to adoption of legal regulations on OTA. For the time being, the binding maximum limits on OTA appear to exist only in the European Union (EU) (see infra). On the global level, debate on the feasibility of establishing the maximum limits on OTA has taken place at the Codex Alimentarius Commission (CAC), the joint intergovernmental body established by the FAO and WHO responsible for implementing the 
Joint FAO/WHO Food Standards Programme. After the Joint Food and Agricultural Organization (FAO)/World Health Organization (WHO) Expert Committee on Food Additives (JECFA), an expert body which provides scientific advice to the CAC repeatedly dealt with OTA in 1991, 1995, 2001, and 2007 , the maximum limit of $5 \mu \mathrm{g} / \mathrm{kg}$ with respect to wheat, barley, and rye has been recently established under the Codex General Standard for Contaminants and Toxins in Food and Feed [363]. In addition, there are four codes of practice that aim at the prevention and reduction of OTA contamination in cereals [364], wine [365], coffee [366], and [367] adopted between 2007 and 2014 [368]. Although the Codex Alimentarius standards are not per se binding, their importance stems especially from the fact the World Trade Organization (WTO) considers the measures taken by its Member States in conformity with the Codex Alimentarius standards to be science-based, appropriate, and nondiscriminatory under the WTO Agreement on the Application of Sanitary and Phytosanitary Measures signed in 1994 and thus does not treat them as breaches of world trade rules.

As far as the existing limits on OTA are concerned, those of the EU are generally assessed to be the most comprehensive and detailed [359].

As for the limits on OTA in food, these were first established on the EU level by the Commission Regulation (EC) No 472/2002 [369] of 12 March 2002 amending Regulation (EC) No 466/2001 [370] setting maximum levels for certain contaminants in foodstuffs (see Table 13). As the Regulation No 466/2001 was repeatedly amended, in 2006, it was replaced by completely a new act, Commission Regulation (EC) No 1881/2006 of 19 December 2006, setting maximum levels for certain contaminants in foodstuffs [371]. The adoption of Regulation No 1881/2006 was based on the scientific opinion of the Scientific Panel on contaminants in the Food Chain of the EFSA adopted on 4 April 2006, which updated the earlier opinion of the Scientific Committee on Food on OTA adopted on 17 September 1998 [372].

Table 13. The first maximum levels of OTA in foodstuffs under Regulation 466/2001 as amended by Regulation 472/2002.

\begin{tabular}{cc}
\hline Foodstuffs & Maximum levels (ng/g) \\
\hline Cereals (including rice and buckwheat) and derived cereal products & 5 \\
\hline Raw cereal grains (including raw rice and buckwheat) & 5 \\
\hline $\begin{array}{c}\text { All products derived from cereals (including processed cereal } \\
\text { products and cereal grains intended for direct human consumption) }\end{array}$ & 3 \\
\hline Dried vine fruit (currants, raisins and sultanas) & 10 \\
\hline $\begin{array}{c}\text { Green and roasted coffee and coffee products, wine, beer, grape } \\
\text { juice, cocoa and cocoa products, and spices }\end{array}$ & - \\
\hline
\end{tabular}

In the EU, the Regulation 1881/2006 remains in force today, although it has been amended nearly 26 times. As of February 2016, the Regulation No 1881/2006 sets the maximum limits on OTA not only in cereals (both in the unprocessed cereals and cereal products) but in a wide variety of other food commodities as well (see Table 14). These limits are legally binding on all 28 EU Member States, which are obliged to apply these rules in full.

Apart from setting binding limits on OTA in food, since 2002, the EU has also unified the methods of sampling and analysis for purposes of the official control of the levels of mycotoxins in foodstuffs performed by the authorities of the Member States (first by the Commission Directive 2002/26/EC of 13 March 2002, later replaced by the Commission Regulation (EC) No 401/2006 of 23 February 2006 which remains in force today).

As for OTA in feed, however, up to now, only a non-binding recommendation exists with respect to cereal feed, and feed for pigs and poultry on the EU level (Commission Recommendation 2006/576/EC [373] of 17 August 2006 on the presence of deoxynivalenol, zearalenone, OTA, T-2 and HT-2, and fumonisins in products intended for animal feeding). For details, see Table 15. 
Table 14. Maximum levels of OTA in foodstuffs under Regulation 1881/2006 as in force.

\begin{tabular}{|c|c|c|}
\hline Code & Foodstuffs & Maximum Levels (ng/g) \\
\hline 2.2 .1 & Unprocessed cereals & 5.0 \\
\hline 2.2.2. & $\begin{array}{l}\text { All products derived from unprocessed cereals, including processed cereal products and cereals intended for direct human consumption with } \\
\text { the exception of foodstuffs listed in } 2.2 .9,2.2 .10 \text {, and } 2.2 .13\end{array}$ & 3.0 \\
\hline 2.2 .3 & Dried vine fruit (currants, raisins, and sultanas) & 10.0 \\
\hline 2.2.4 & Roasted coffee beans and ground roasted coffee, excluding soluble coffee & 5.0 \\
\hline 2.2 .5 & Soluble coffee (instant coffee) & 10.0 \\
\hline 2.2 .6 & Wine (including sparkling wine, excluding liqueur wine and wine with an alcoholic strength of not less than 15 vol \%) and fruit wine & 2.0 \\
\hline 2.2.7 & Aromatized wine, aromatized wine-based drinks, and aromatized wine-product cocktails & 2.0 \\
\hline 2.2.8 & $\begin{array}{l}\text { Grape juice, concentrated grape juice as reconstituted, grape nectar, grape must and concentrated grape must as reconstituted, intended for } \\
\text { direct human consumption }\end{array}$ & 2.0 \\
\hline 2.2 .9 & Processed cereal-based foods and baby foods for infants and young children & 0.50 \\
\hline 2.2 .10 & Dietary foods for special medical purposes intended specifically for infants & 0.50 \\
\hline \multirow[t]{4}{*}{ 2.2.11. } & Spices, including dried spices & \\
\hline & Piper spp. (fruits thereof, including white and black pepper), Myristica fragrans (nutmeg), Zingiber officinale (ginger), Curcuma longa (turmeric) & 15 \\
\hline & Capsicum spp. (dried fruits thereof, whole or ground, including chilies, chili powder, cayenne, and paprika) & 20 \\
\hline & Mixtures of spices containing one of the abovementioned spices & 15 \\
\hline 2.2.12. & Liquorice (Glycyrrhiza glabra, Glycyrrhiza inflate and other species) & \\
\hline 2.2.12.1. & Liquorice root, ingredient for herbal infusion & 20 \\
\hline 2.2.12.2. & Liquorice extract for use in food in particular beverages and confectionary & 80 \\
\hline 2.2.13. & Wheat gluten not sold directly to the consumer & 8.0 \\
\hline
\end{tabular}

Table 15. Guidance values for OTA under Commission Recommendation 2006/576/EC as in force.

Feed

Guidance Value in $\mathrm{mg} / \mathrm{kg}$ Relative to Feedstuffs with a Moisture Content of $12 \%$

\begin{tabular}{cc}
\hline Feed & Guidance Value in $\mathbf{~ m g} / \mathbf{k g}$ Relative to Feedstuffs with a Moisture Content of $\mathbf{1 2} \%$ \\
\hline Feed materials *-Cereals and cereal products ** & 0.25 \\
Complementary and complete feedstuffs & 0.05 \\
- Complementary and complete feedstuffs for pigs & 0.1 \\
\hline -Complementary and complete feedstuffs for poultry & \\
\hline
\end{tabular}

* Particular attention must be paid to cereals and cereals products fed directly to the animals that their use in a daily ration should not lead to the animal being exposed to a higher level of these mycotoxins than the corresponding levels of exposure where only the complete feedstuffs are used in a daily ration. ** The term "Cereals and cereal products" includes not only the feed materials listed under Heading 1, "Cereal grains, their products and by-products," of the non-exclusive list of main feed materials referred to in Part B of the Annex to Council Directive 96/25/EC of 29 April 1996 on the circulation and use of feed materials (OJ L 125, 23.5.1996, p. 35), but also other feed materials derived from cereals in particular cereal forages and roughages. 
There are, however, approaches to legal regulation of OTA other than establishing and enforcing the binding maximum limits on OTA in food and feed commodities as in the EU. Most notably, no binding limits on OTA in food or feed exist in the USA. Even more strikingly, no advisory or regulatory action limits have been established by the US authorities. Instead, the US Food and Drug Administration (FDA), acting under the Federal Food, Drug and Cosmetic Act (FFDCA), has instead consistently relied on laying down good agricultural and manufacturing practices and on requiring the implementation of food safety plans in food industry undertakings [358]. In extension, the FDA monitors the compliance with these practices and the presence of OTA in domestic and imported foods (Food Compliance Programme No 7307.001 entitled "Mycotoxins in Domestic and Imported Foods"). An approach analogous to that of the USA has been adopted by a range of other countries such as Australia, Canada, and Japan [374].

For some authors, the US approach to regulating mycotoxins including OTA is clearly preferable because it is seen as an option that might "diffuse trade frictions, and at the same time help reduce economic losses from mycotoxin contamination and divergent standards" [375]. The truth is that the US approach seems to exert a non-negligible influence on the international level, e.g., within the CAC, which has, as mentioned above, adopted four codes of good practice with the aim of reducing the OTA occurrence in several food commodities that are commercially important.

To sum up, 50 years after the discovery of OTA, differences in how to legally regulate mycotoxins including OTA are still marked. However, even in an era when further liberalization of world trade is envisaged (e.g., a project of the Transatlantic Trade and Investment Partnership and the TTIP between the USA and the EU), due to economic and political controversies linked to the existing policies on mycotoxins, it cannot be expected that some harmonized approach to legally regulating mycotoxins including OTA will be easily established on a global level [375-377].

\section{Conclusions}

OTA is ubiquitously found all over the world in many foodstuffs and feedstuffs. OTA is recognized for its nephrotoxicity and, to date has been identified as one of the most potent renal carcinogens in rodents ever studied by the National Cancer Institute/National Toxicological Program (NCI/NTP) [181]. OTA is deleterious for the pig and poultry industries. For human beings, many authors consider it to be the main contributor in the pathogenesis of Balkan endemic nephropathy and some nephropathies in other parts of the world.

The development of effective strategies alleviating OTA-induced toxicity is very complex because the mechanism of action of OTA is still unclear. The toxic effect is the result of many effects such as the inhibition of protein synthesis, direct genotoxicity, and cell cycle arrest. Inhibition of OTA uptake and stimulation of OTA elimination of the body preventing OTA accumulation will be promising approaches [378].

Since its discovery in 1965, numerous studies have been performed with respect to OTA, which have permitted the establishment of different mechanisms for OTA nephrotoxicity and carcinogenicity (summarized in Figures 6 and 7). The mechanisms leading to OTA nephrotoxicity, its hepatotoxicity and immunotoxicity, can be linked to inhibition of protein synthesis, lipoperoxidation, and modulation of MAP kinase cascade (Figure 6), whereas its carcinogenicity arises after the metabolic activation of OTA in a way similar to pentachlorophenol derivatives (Figure 7). 


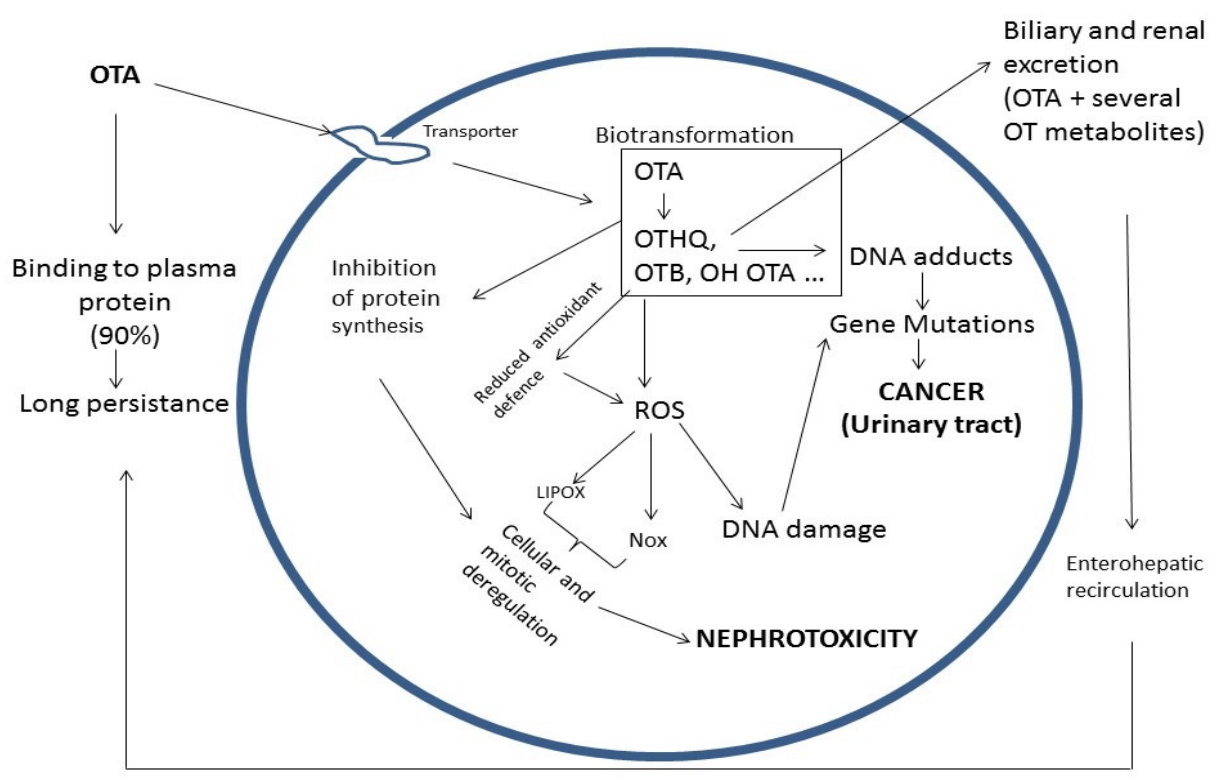

Figure 6. Summary of biochemical effects of OTA. Explanations: OTA: Ochratoxin A; OTHQ: Hydroxyl quinone ochratoxin; OTB: Dechlorinated ochratoxin; LIPOX: Lipoperoxidation; Nox: Nitrogen oxide; ROS: Reactive oxygen species.

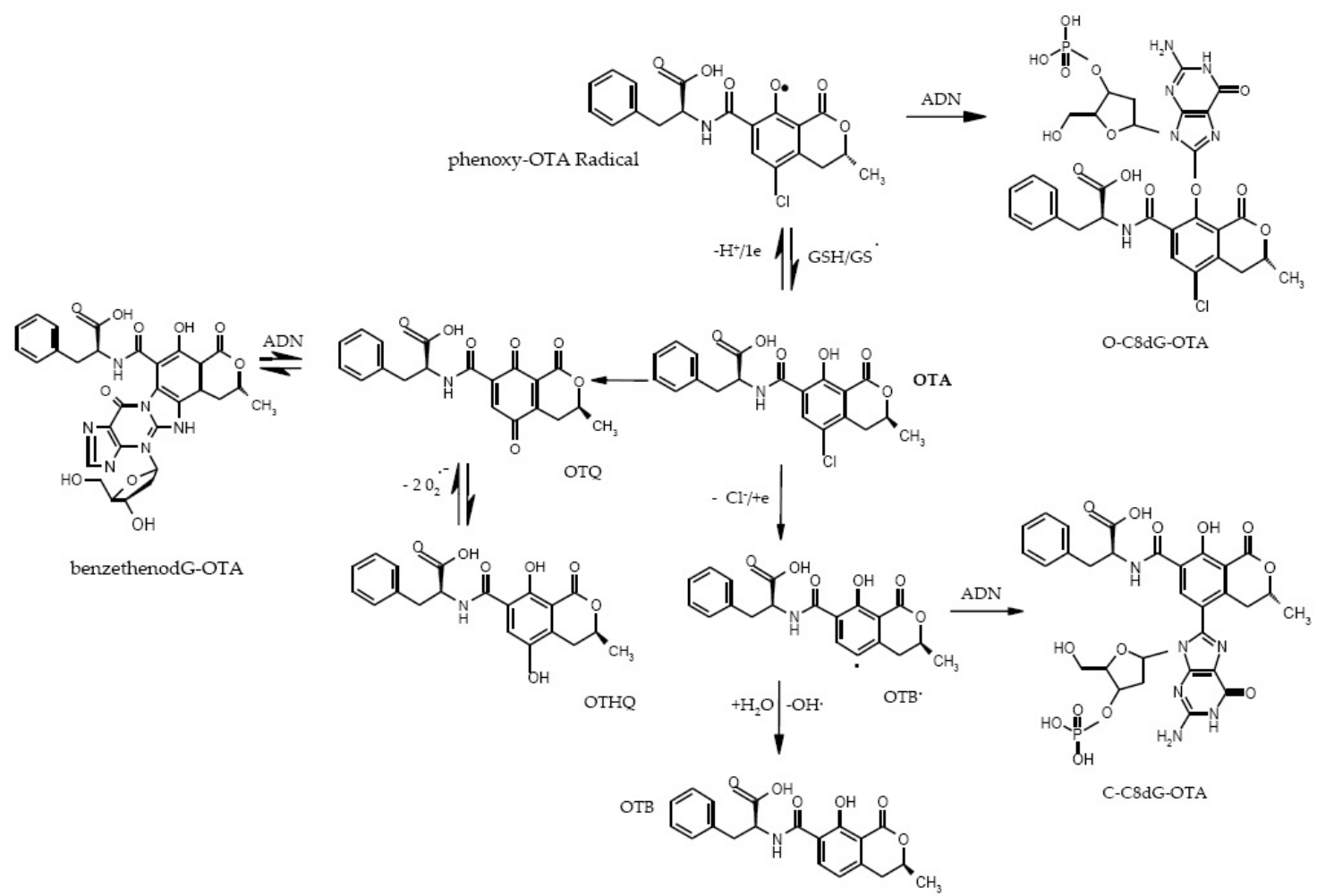

Figure 7. Metabolic activation of ochratoxin leading to DNA adducts. OTA: Ochratoxin A; OTHQ: Hydroxyl quinone ochratoxin; OTQ: Quinone ochratoxin; OTB: Dechlorinated ochratoxin; GSH: Reduced glutathione; GS: Oxidized glutathione; dG-OTA: Guanine OTA adduct.

OTA forms covalent DNA adducts through radical and benzoquinone intermediates. The OTHQ metabolite of OTA can undergo an autoxidative process to generate the quinone electrophile OTQ that reacts with DNA. In addition, the formation of OTQ or phenoxy and aryl radicals can lead to increased ROS production that causes cytotoxicity. Radical species generate a C-bound C8-dG adduct, 
while benzetheno-type DNA adducts are expected from the quinone electrophile. The quinone-type adducts form faster in cells and stem from P450 activation of OTA. The C-bound C8-OTA adduct forms at a slower rate and is predicted to stem from reductive dehalogenation of OTA (via GSH and cyclooxygenase or lipoxygenase). The $\mathrm{C} 5-\mathrm{Cl}$ atom is critical for DNA adduction (genotoxicity) but not for cytotoxicity (OTB is cytotoxic but not genotoxic) (Figure 7).

Several quinone derivatives have been isolated from blood and urine and also in human or animal tissues exposed to OTA. The OTB-dG adduct is consistently found by ${ }^{32} \mathrm{P}$-postlabeling in kidney DNA from OTA-treated rats, pigs, and humans. These metabolites and this adduct could serve as biomarker for OTA exposure.

Increases in carcinogenicity and genotoxicity during co-exposure with citrinin (CIT), fumonisin (FB), or both can be explained by both factors. FB and CIT induce COX2, thus favoring the biotransformation of OTA into a genotoxic compound. Moreover, the quinone methide structure of CIT could easily explain the generation of DNA adduct. It may be capable of oxidizing OTA into the phenoxyl radical to promote $\mathrm{C}-\mathrm{C} 8$ adduct formation. The new findings on OTA mutagenicity favor direct genotoxicity and rule out oxidative DNA damage as a contributor to the induction of deletion mutations or renal carcinogenesis. Therefore, further research should focus on co-exposure.

Altogether, OTA is a complete carcinogen, active since the earliest stage of life. Intake evaluation based on real analysis shows that the daily intake was three times greater than the virtual safety dose of $4 \mathrm{ng} / \mathrm{kg} \mathrm{bw} /$ day—against carcinogenicity (intake per day $648 \mathrm{ng} / 60 \mathrm{~kg}$ adult) [379].

Maternal-fetal risk assessment of OTA during pregnancy was conducted using the benchmark dose approach for genotoxic carcinogens. Considering the sensitivity of a fetus, risk reduction is a high priority. It is essential to keep exposure to OTA as low as possible in women, notably during pregnancy [380].

Among the professional community, it is agreed that OTA is one of the five most agriculturally important mycotoxins; therefore, continued attention must be paid to research on ochratoxins and OTA in order to elucidate their metabolism, genotoxicity, and mechanism of action for renal carcinogenicity, with the ultimate aim of protecting public health and preventing economic losses.

Acknowledgments: The authors gratefully acknowledge financial support from the specific research project (No. 2113/2016) of Faculty of Science, University Hradec Kralove, Czech Republic, and from the project of Ministry of Health, Czech Republic-conceptual development of research organization ("National Institute of Public Health-NIPH, IN 75010330").

Dedicated to the memory of all researchers who substantially contributed to OTA research and helped to build general knowledge on OTA. Apologies to all the collegues whose important work on OTA is not highlighghted in this article.

Author Contributions: Frantisek Malir, Vladimir Ostry, Jan Malir and Jakub Toman reviewed the available data and wrote the core of the paper. Annie Pfohl-Leszkowicz performed a scientific supervision and manuscript revision. Jan Malir is responsible for a chapter on legal regulation of OTA and the correction of the English. All authors read and approved the final manuscript. The authors thank to Yann Grosse for all informations from the IARC, Lyon.

Conflicts of Interest: The authors do not declare any conflict of interests.

\section{Abbreviations}

$\begin{array}{ll}\text { 10-OHOA } & \text { 10-hydroxy ochratoxin A } \\ \text { 10-OHOA-Me } & \text { 10-hydroxy ochratoxin A methyl ester } \\ \text { 2'-DC-OTA } & \text { 2'-ochratoxin A decarboxylated } \\ \text { 2'R-OTA } & \text { 2'R-ochratoxin A } \\ \text { 4R-OHOA } & \text { 4R-hydroxy ochratoxin A } \\ \text { 4R-OHOA-Me } & \text { 4R-hydroxy ochratoxin A methyl ester } \\ \text { 4S-OHOA } & \text { 4S-hydroxy ochratoxin A } \\ \text { Acyl-hexose-OTA } & \text { conjugate ochratoxin A-acyl hexose } \\ \text { Acyl-pentose OTA } & \text { conjugate ochratoxin A-acyl pentose } \\ \text { BEN } & \text { Balkan endemic nephropathy }\end{array}$




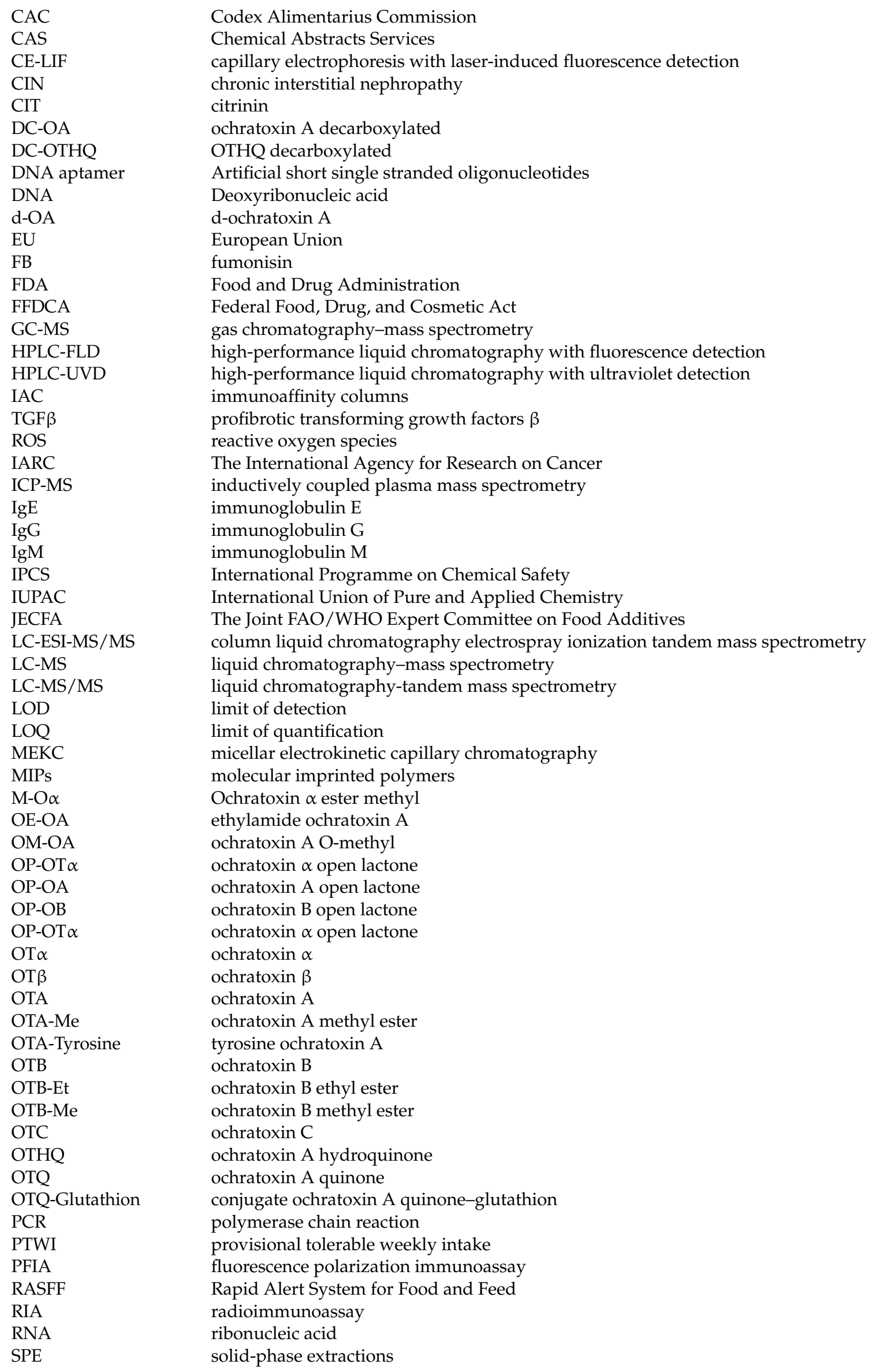




$\begin{array}{ll}\text { TDI } & \text { tolerable daily intake } \\ \text { TLC } & \text { solid thin layer chromatography } \\ \text { TTIP } & \text { The Transatlantic Trade and Investment Partnership } \\ \text { TWI } & \text { tolerable weekly intake } \\ \text { UTT } & \text { urinary tract tumors } \\ \text { WHO } & \text { World Health Organization } \\ \text { WTO } & \text { World Trade Organization } \\ \text { EDI } & \text { exposure daily intake }\end{array}$

\section{References}

1. Jørgensen, K. Survey of pork, poultry, coffee, beer and pulses for Ochratoxin A. Food Addit. Contam. 1998, 15, 550-554. [CrossRef] [PubMed]

2. Santos, L.; Marin, S.; Sanchis, V.; Ramos, A.J. Screening of mycotoxin multicontamination in medicinal and aromatic herbs sampled in Spain. J. Sci. Food Agric. 2009, 89, 1802-1807. [CrossRef]

3. Van der Merwe, K.J.; Steyn, P.S.; Fourie, L. Ochratoxin A, a toxic metabolite produced by Aspergillus ochraceus Wilh. Nature 1965, 205, 1112-1113. [CrossRef] [PubMed]

4. Van der Merwe, K.J.; Steyn, P.S.; Fourie, L. Mycotoxins Part II. The constitution of Ochratoxins A, B and C, metabolites of Aspergillus ochraceus Wilh. J. Chem. Soc. 1965, 204, 7083-7088. [CrossRef]

5. Weidenbach, A.; Petzinger, E. Ochratoxin A: Toxicology of an abundant mycotoxin. Curr. Top. Pharmacol. 2004, 8, 235-250.

6. Sava, V.; Reunova, O.; Velasquez, A.; Harbison, R.; Sanchez-Ramos, J. Acute neurotoxic effects of the fungal metabolite Ochratoxin A. Neurotoxicology 2006, 27, 82-92. [CrossRef] [PubMed]

7. Sava, V.; Velasquez, A.; Song, S.; Sanchez-Ramos, J. Adult hippocampal neural stem/progenitor cells in vitro are vulnerable to the mycotoxin Ochratoxin A. Toxicol. Sci. 2007, 98, 187-197. [CrossRef] [PubMed]

8. Pfohl-Leszkowicz, A.; Manderville, R. Ochratoxin A: An overview on toxicity and carcinogenicity in animals and humans. Mol. Nutr. Food Res. 2007, 51, 61-99. [CrossRef] [PubMed]

9. Malir, F.; Ostry, V.; Novotna, E. Toxicity of the mycotoxin Ochratoxin A in the light of recent data. Toxin Rev. 2013, 32, 19-33. [CrossRef]

10. Malir, F.; Ostry, V.; Pfohl-Leszkowicz, A.; Novotna, E. Ochratoxin A: Developmental and reproductive toxicity-An overview. Birth Defects Res. B 2013, 98, 493-502. [CrossRef] [PubMed]

11. IARC. Monographs on the Evaluation of Carcinogenic Risks to Humans: Some Naturally Occuring Substances: Food Items and Costituents, Heterocyclic Aromatic Amines and Mycotoxins; IARC: Lyon, France, 1993; Volume 56, pp. 489-524.

12. Castegnaro, M.; Mohr, U.; Pfohl-Leszkowicz, A.; Estève, J.; Steinmann, J.; Tillmann, T.; Michelon, J.; Bartsch, H. Sex-and strain-specific induction of renal tumors by Ochratoxin A in rats correlates with DNA adduction. IARC 1998, 77, 70-75. [CrossRef]

13. Pfohl-Leszkowicz, A.; Pinelli, E.; Bartsch, H.; Mohr, U.; Castegnaro, M. Sex and strain differences in Ochratoxin A metabolism and DNA adduction in two strains of rats. Mol. Carcinog. 1998, 23, 76-83. [CrossRef]

14. Pfohl-Leszkowicz, A.; Petkova-Bocharova, T.; Chernozemsky, I.; Castegnaro, M. Balkan Endemic Nephropathy and associated Urinary tract tumours: A review on aetiological causes and the potential role of mycotoxins. Food Addit. Contam. 2002, 19, 282-302. [CrossRef] [PubMed]

15. Hsuuw, Y.; Chan, W.; Yu, J. Ochratoxin A inhibits mouse embryonic development by activating A mitochondrion-dependent apoptotic signaling pathway. Int. J. Mol. Sci. 2013, 14, 935-953. [CrossRef] [PubMed]

16. Pfohl-Leszkowicz, A.; Tozlovanu, M.; Manderville, R.; Peraica, M.; Castegnaro, M.; Stefanovic, V. New molecular and field evidences for the implication of mycotoxins but not aristolochic acid in human nephropathy and Urinary tract tumor. Mol. Nutr. Food Res. 2007, 51, 1131-1146. [CrossRef] [PubMed]

17. Pfohl-Leszkowicz, A. Ochratoxin A and aristolochic acid involvement in nephropathies and associated Urothelial tract tumours. Arch. Ind. Hyg. Toxicol. 2009, 60, 465-483. [CrossRef] [PubMed]

18. Degen, G.; Mayer, S.; Blaszkewicz, M. Biomonitoring of Ochratoxin A in grain workers. Mycotoxin Res. 2007, 23, 88-93. [CrossRef] [PubMed] 
19. Iavicoli, I.; Brera, C.; Carelli, G.; Caputi, R.; Marinaccio, A.; Miraglia, M. External and internal dose in subjects occupationally exposed to Ochratoxin A. Int. Arch. Occup. Environ. Health 2002, 75, 381-386. [CrossRef] [PubMed]

20. Halstensen, A.S.; Nordby, K.C.; Elen, O.; Eduard, W. Ochratoxin in grain dust-estimated exposure and relations to agricultural practices in grain production. Ann. Agric. Environ. Med. 2004, 11, 245-254. [PubMed]

21. Abarca, M.L.; Bragulat, M.R.; Castella, G.; Cabañes, F.J. Ochratoxin A production by strains of Aspergillus niger var. niger. Appl. Environ. Microbiol. 1994, 60, 2650-2652. [PubMed]

22. Teren, J.; Varga, J.; Hamari, Z.; Rinyu, E.; Kevei, E. Immunochemical detection of Ochratoxin A in black Aspergillus strains. Mycopathologia 1996, 134, 171-176. [CrossRef] [PubMed]

23. Pitt, J.I. Biology and ecology of toxigenic Penicillium species. In Mycotoxins and Food Safety; DeVries, J.W., Truckseess, M.W., Jackson, L.S., Eds.; Kluwer Academic, Plenum Publisher: New York, NY, USA, 2002; pp. 29-41.

24. Medina, A.; Mateo, R.; López-Ocaña, L.; Valle-Algarra, F.M.; Jiménez, M. Study of Spanish grape mycobiota and Ochratoxin A production by isolates of Aspergillus tubingensis and other members of Aspergillus section Nigri. Appl. Environ. Microbiol. 2005, 71, 4696-4702. [CrossRef] [PubMed]

25. Frisvad, J.C.; Frank, J.M.; Houbraken, J.A.M.P.; Kuijpers, A.F.A.; Samson, R.A. New Ochratoxin A producing species of Aspergillus section Circumdati. Stud. Mycol. 2004, 50, $23-43$.

26. Samson, R.A.; Houbraken, J.A.M.P.; Kuijpers, A.F.A.; Frank, J.M.; Frisvad, J.C. New Ochratoxin A or sclerotium producing species in Aspergillus section Nigri. Stud. Mycol. 2004, 50, 45-61.

27. Van Walbeek, W.; Scott, P.M.; Harwig, J.; Lawrence, J.W. Penicillium viridicatum Westling: A new source of Ochratoxin A. Can. J. Microbiol. 1969, 15, 1281-1285. [CrossRef] [PubMed]

28. Samson, R.A.; Frisvad, J.C. Penicillium subgenus Penicillium: New taxonomic schemes and mycotoxins and other extrolites. Stud. Mycol. 2004, 49, 260.

29. Ciegler, A.; Fennell, D.I.; Sansing, G.A.; Detroy, R.W.; Bennett, G.A. Mycotoxin-producing strains of Penicillium viridicatum: Classification into subgroups. Appl. Microbiol. 1973, 26, 271-278. [PubMed]

30. Pitt, J.I. The Genus Penicillium and Its Teleomorphic States Eupenicillium and Talaromyces; Academic Press, Inc.: London, UK, 1979.

31. Larsen, T.O.; Svendsen, A.; Smedsgaard, J. Biochemical characterization of Ochratoxin A-Producing strains of the genus Penicillium. Appl. Env. Microb. 2001, 67, 3630-3635. [CrossRef] [PubMed]

32. Bogs, C.; Battilani, P.; Geisen, R. Development of a molecular detection and differentiation system for Ochratoxin A producing Penicillium species and its application to analyse the occurrence of Penicillium nordicum in cured meats. Int. J. Food Microbiol. 2006, 107, 39-47. [CrossRef] [PubMed]

33. Ostry, V.; Malir, F.; Ruprich, J. Producers and important dietary sources of Ochratoxin A and citrinin. Toxins 2013, 5, 1574-1586. [CrossRef] [PubMed]

34. Budavari, S., Ed.; The Merck Index, 11th ed.; Merck \& Co.: Rahway, NJ, USA, 1989; p. 1068.

35. Kuiper-Goodman, T.; Scott, P.M. Risk assessment of the mycotoxin Ochratoxin A. Biomed. Environ. Sci. 1989, 2, 179-248. [PubMed]

36. Pohland, A.E.; Schuller, P.L.; Steyn, P.S.; van Egmond, H.P. Physico-chemical data for some selected mycotoxins. Pure Appl. Chem. 1982, 54, 2219-2228. [CrossRef]

37. WHO. Selected Mycotoxins: Ochratoxins, Trichothecenes, Ergot; Environmental Health Criteria, WHO: Geneva, Switzerland, 1990; Volume 105, pp. 1-260.

38. Müller, H.M. Decontamination of mycotoxins. 1. Physical process (Ger.). Übersicht. Tieremahr. 1982, 10, 95-122.

39. Castegnaro, M., Barek, J., Frémy, J.-M., Lafontaine, M., Miraglia, M., Sansone, E.B., Telling, G.M., Eds.; Laboratory Decontamination and Destruction of Carcinogens in Laboratory Wastes: Some Mycotoxins; IARC Scientific Publications: Lyon, France, 1991; Volume 113, pp. 9-16.

40. El Khoury, A.; Atoui, A. Ochratoxin A: General overview and actual molecular status. Toxins 2010, 2, 461-493. [CrossRef] [PubMed]

41. Malir, F.; Ostry, V.; Pfohl-Leszkowicz, A.; Toman, J.; Bazin, I.; Roubal, T. Transfer of Ochratoxin A into tea and coffee beverages. Toxins 2014, 6, 3438-3453. [CrossRef] [PubMed]

42. Bruinink, A.; Rasonyi, T.; Sidler, C. Differences in neurotoxic effects of Ochratoxin A, ochracin and ochratoxin- $\alpha$ in vitro. Nat. Toxins 1998, 6, 173-177. [CrossRef] 
43. Faucet-Marquis, V.; Pont, F.; Størmer, F.; Rizk, T.; Castegnaro, M.; Pfohl-Leszkowicz, A. Evidence of a new dechlorinated Ochratoxin A derivative formed in opossum kidney cell cultures after pretreatment by modulators of glutathione pathways: Correlation with DNA-adduct formation. Mol. Nutr. Food Res. 2006, 50, 530-542. [CrossRef] [PubMed]

44. Tozlovanu, M.; Faucet-Marquis, V.; Pfohl-Leszkowicz, A.; Manderville, R.A. Genotoxicity of the hydroquinone metabolite of Ochratoxin A: Structure-activity relationships for covalent DNA adduction. Chem. Res. Toxicol. 2006, 19, 1241-1247. [CrossRef] [PubMed]

45. Ringot, D.; Chango, A.; Schneider, Y.J.; Larondelle, Y. Toxicokinetics and toxicodynamics of Ochratoxin A, an update. Chem. Biol. Interact. 2006, 159, 18-46. [CrossRef] [PubMed]

46. Azpilicueta, C.A.; Arbeloa, M.I.; de Maquirriain, P.F.J. Natural and syntethic occurring forms of the ochratoxins. In Food Chemistry Research Developments; Papadopoulos, K.N., Ed.; Nova Science Publishers: New York, NY, USA, 2008.

47. Wu, Q.; Dohnal, V.; Huang, L.; Kuca, K.; Wang, X.; Chen, G.; Yuan, Z. Metabolic pathways of Ochratoxin A. Curr. Drug Metab. 2011, 12, 1-10. [CrossRef] [PubMed]

48. Han, Z.; Tangni, E.K.; di Mavungu, J.D.; Vanhaecke, L.; de Saeger, S.; Wu, A.; Callebaut, A. In vitro glucuronidation of Ochratoxin A by rat liver microsomes. Toxins 2013, 5, 2671-2685. [CrossRef] [PubMed]

49. Yang, S.; Zhang, H.; de Saeger, S.; de Boevre, M.; Sun, F.; Zhang, S.; Cao, X.; Wang, Z. In vitro and in vivo metabolism of Ochratoxin A: A comparative study using ultra-performance liquid chromatography-quadrupole/time-of-flight hybrid mass spectrometry. Anal. Bioanal. Chem. 2015, 407, 3579-3589. [CrossRef] [PubMed]

50. Heussner, A.H.; Bingle, L.E.H. Comparative Ochratoxin toxicity: A review of the available data. Toxins 2015, 7, 4253-4282. [CrossRef] [PubMed]

51. Grosse, Y.; Chekir-Ghedira, L.; Huc, A.; Obrecht-Pflumio, S.; Dirheimer, G.; Bacha, H.; Pfohl-Leszkowicz, A. Retinol, ascorbic acid and A-tocopherol prevent DNA adduct formation in mice treated with the mycotoxins Ochratoxin A and zearalenone. Cancer Lett. 1997, 114, 225-229. [CrossRef]

52. Galtier, P.; Alvinerie, M. In vitro Transformation of Ochratoxin A by animal microbioal floras. Ann. Rech. Vet. 1976, 7, 91-98. [PubMed]

53. Pitout, M.J. The hydrolysis of Ochratoxin A by some proteolytic enzymes. Biochem. Pharmacol. 1969, 18, 485-491. [CrossRef]

54. Hult, K.; Hokby, E.; Gatenbeck, S. Analysis of ochratoxin B alone and in the presence of Ochratoxin A, using carboxypeptidase A. Appl. Environ. Microbiol. 1977, 33, 1275-1277. [PubMed]

55. Størmer, F.C.; Hansen, C.E.; Pedersen, J.I.; Hvistendahl, G.; Aasen, A.J. Formation of (4R)and (4S)-4-hydroxyochratoxin A from Ochratoxin A by liver microsomes from various species. Appl. Environ. Microbiol. 1981, 42, 1051-1056. [PubMed]

56. Størmer, F.C.; Storen, O.; Hansen, C.E.; Pedersen, J.I.; Aasen, A.J. Formation of (4R)- and (4S)-4-hydroxyochratoxin A and 10-hydroxyochratoxin A from Ochratoxin A by rabbit liver microsomes. Appl. Environ. Microbiol. 1983, 45, 1183-1187.

57. Li, S.; Marquardt, R.; Frohlich, A. Identification of Ochratoxins and some of their metabolites in bile and urine of rats. Food. Chem. Toxicol. 2000, 38, 141-152. [CrossRef]

58. Gillman, I.; Clark, T.; Manderville, R. Oxidation of Ochratoxin A by an Fe-porphyrin system: Model for enzymatic activation and DNA cleavage. Chem. Res. Toxicol. 1998, 12, 1066-1076. [CrossRef]

59. Dai, J.; Park, G.; Wright, M.; Adams, M.; Akman, S.; Manderville, R. Detection and characterization of a glutathione conjugate of Ochratoxin A. Chem. Res. Toxicol. 2002, 15, 1581-1588. [CrossRef] [PubMed]

60. Gross-Steinmeyer, K.; Weymann, J.; Hege, H.; Metzler, M. Metabolism and lack of DNA reactivity of the mycotoxin Ochratoxin A in cultured rat and human primary hepatocytes. J. Agric. Food Chem. 2002, 50, 938-945. [CrossRef] [PubMed]

61. Xiao, H.; Marquardt, R.; Frohlich, A.; Ling, Y. Synthesis and structural elucidation of analogs of Ochratoxin A. J. Agric. Food Chem. 1995, 43, 524-530. [CrossRef]

62. Creppy, E.; Chakor, K.; Fisher, M.; Dirheimer, G. The mycotoxin Ochratoxin A is a substrate for phenylalanine hydroxylase in isolated rat hepatocytes and in Vivo. Arch. Toxicol. 1990, 64, 279-284. [CrossRef] [PubMed]

63. Tozlovanu, M.; Canadas, D.; Pfohl-Leszkowicz, A.; Frenette, C.; Paugh, R.J.; Pfohl-Leszkowicz, A.; Frenette, C.; Paugh, R.J.; Manderville, R.A. Glutathione conjugates of ochratoxin A as biomarkers of exposure. Arh. Hig. Rada. Toksikol. 2012, 63, 417-427. [CrossRef] [PubMed] 
64. Pfohl-Leszkowicz, A.; Gabryelski, W.; Manderville, R. Formation of 2'-deoxyguanosine-carbon 8-bound Ochratoxin A adduct in rat kidney DNA. Mol. Nutr. Food Res. 2009, 53, 154-155. [CrossRef] [PubMed]

65. Hadjeba-Medjdoub, K.; Tozlovanu, M.; Pfohl-Leszkowicz, A.; Frenette, C.; Paugh, R.; Manderville, R. Structure-activity relationships imply different mechanisms of action for Ochratoxin A-mediated cytotoxicity and genotoxicity. Chem. Res. Toxicol. 2012, 25, 181-190. [CrossRef] [PubMed]

66. Cramer, B.; Königs, M.; Humpf, H. Identification and in vitro cytotoxicity of Ochratoxin A degradation products formed during coffee roasting. J. Agric. Food Chem. 2008, 56, 5673-5681. [CrossRef] [PubMed]

67. Bittner, A.; Cramer, B.; Harrer, H.; Humpf, H. Structure elucidation and in vitro cytotoxicity of ochratoxin A amide, a new degradation product of Ochratoxin A. Mycotoxin Res. 2015, 31, 83-90. [CrossRef] [PubMed]

68. Nesheim, S.; Hardin, N.F.; Francis, O.J.; Langham, W.S. Analysis of Ochratoxins A and B and their esters in barley, using partition and thin-layer chromatography. I. Development of the method. J. Assoc. Off. Anal. Chem. 1973, 56, 817-821.

69. Nesheim, S. Analysis of Ochratoxins A and B and their esters in barley, using partition and thin-layer chromatography. II. Collaborative study. J. Assoc. Off. Anal. Chem. 1973, 56, 822-826.

70. Hult, K.; Gatenbeck, S. A spectrophotometric procedure, using carboxypeptidase A, for quantitative measurement of Ochratoxin A. J. Assoc. Off. Anal. Chem. 1976, 59, 128-129. [PubMed]

71. Josefsson, E.; Möller, T. High pressure Iiquid chromatographic determination of Ochratoxin A and zearalenone in cereals. J. Assoc. Off. Anal. Chem. 1979, 62, 1165-1168. [PubMed]

72. Schweighardt, H.; Schuh, M.; Abdelhamid, A.M.; Böhm, J.; Leibetseder, J. Method for quantitative determination of Ochratoxin A in foods and feeds by high-pressure Liquid chromatography (HPLC) (Ger.). Z. Lebensmittel. Untersuch. Forsch. 1980, 170, 355-359. [CrossRef]

73. Hunt, D.C.; McConnie, B.R.; Crosby, N.T. Confirmation of Ochratoxin A by chemical derivatisation and high-performance liquid chromatography. Analyst 1980, 105, 89-90. [CrossRef]

74. Howell, M.V.; Taylor, P.W. Determination of aflatoxins, Ochratoxin A, and zearalenone in mixed feeds, with detection by thin layer chromatography or high performance liquid chromatography. J. Assoc. Off. Anal. Chem. 1981, 64, 1356-1363. [PubMed]

75. Aalund, O.; Brunfeldt, K.; Hald, B.; Krogh, P.; Poulsen, K. A radioimmunoassay for Ochratoxin A: A preliminary investigation. Acta Pathol. Microbiol. Scand. Sect. C 1975, 83, 390-392. [CrossRef]

76. Pestka, J.J.; Steinert, B.W.; Chu, F.S. Enzyme-linked immunosorbent assay for detection of Ochratoxin A. Appl. Environ. Microbiol. 1981, 41, 1472-1474. [PubMed]

77. Abramson, D. Measurement of Ochratoxin A in barley extracts by liquid-Chromatography-mass spectrometry. J. Chromatogr. 1987, 391, 315-320. [CrossRef]

78. Breitholtz, A.; Olsen, M.; Dahlbäck, A.; Hult, K. Plasma Ochratoxin A levels in three Swedish population surveyed using an ion pair HPLC technique. Food Add. Contam. 1991, 8, 183-192. [CrossRef] [PubMed]

79. Jiao, Y.; Blaas, W.; Rühl, C.; Weber, R. Identification of Ochratoxin A in food samples by chemical derivatization and gas chromatography-Mass spectrometry. J. Chromatogr. 1992, 595, 364-367. [CrossRef]

80. Nesheim, S.; Stack, M.E.; Trucksess, M.W.; Eppley, R.M. Rapid solvent-efficient for liquid chromatographic determination of Ochratoxin A in corn, barley and kidney: Collaborative Study. J. AOAC Int. 1992, 75, 3, 481-487.

81. Kawamura, O.; Maki, S.; Sato, S.; Ueno, Y. Ochratoxin A in livestock and human sera in Japan quantified by a sensitive ELISA. In Human ochratoxicosis and Its Pathologies; Creppy, E.E., Castegnaro, M., Dirheimer, G., Eds.; Colloque INSERM/John Libbey Eurotext: London, UK, 1993; Volume 231, pp. 159-165.

82. Scott, P.M.; Trucksess, M.W. Application of immunoaffinity columns to mycotoxin analysis. J. AOAC Int. 1997, 80, 5, 941-949.

83. Becker, M.; Degelman, P.; Herderich, M.; Schreier, P.; Humpf, H.-U. Column liquid chromatographyelectrospray ionization-tandem mass spectrometry for the analysis of Ochratoxin. J. Chromatogr. A 1998, 818, 260-264. [CrossRef]

84. Jørgensen, K.; Vahl, M. Analysis of Ochratoxin A in pig kidney and rye flour using liquid chromatography tandem mass spectrometry (LC/MS/MS). Food Addit. Contam. 1999, 16, 451-456.

85. Petkova-Bocharova, T.; Castegnaro, M.; Pfohl-Leszkowicz, A.; Garren, L.; Grosso, F.; Nikolov, I.; Vrabcheva, T.; Dragacci, S.; Chernozemsky, I.N. Analysis of Ochratoxin A in serum and urine of inhabitants from an area with Balkan endemic nephropathy: A one-month follow up study. Facta Univ. Ser. Med. Biol. 2003, 10, $62-68$. 
86. Molinié, A.; Faucet, V.; Castegnaro, M.; Pfohl-Leszkowicz, A. Analysis of some breakfast cereals on the French market for their contents of Ochratoxin A, citrinin and fumonisin $\mathrm{B}_{1}$ : Development of a method for simultaneous extraction of Ochratoxin A and citrinin. Food Chem. 2005, 92, 391-400. [CrossRef]

87. Shim, W.-B.; Kolosova, A.Y.; Kim, Y.J.; Yang, Z.Y.; Park, S.J.; Eremin, S.A.; Lee, I.S.; Chung, D.-H. Fluorescence polarization immunoassay based on a monoclonal antibody for the detection of OTA. Int. J. Food Sci. Technol. 2004, 39, 827-837. [CrossRef]

88. Cruz-Aguado, J.A.; Penner, G. Determination of Ochratoxin A with a DNA aptamer. J. Agric. Food Chem. 2008, 56, 10456-10461. [CrossRef] [PubMed]

89. Ahn, J.; Kim, D.; Kim, H.; Jahng, K.Y. Quantitative determination of mycotoxins in urine by LC-MS/MS. Food Addit. Contam. Part A 2010, 27, 1674-1682. [CrossRef] [PubMed]

90. Giesen, C.; Jakubowski, N.; Panne, U.; Weller, M.G. Comparison of ICP-MS and photometric detection of an immunoassay for the determination of Ochratoxin a in wine. J. Anal. At. Spectrom. 2010, 25, 1567-1572. [CrossRef]

91. Ediage, E.N.; di Mavungu, J.D.; Song, S.; Wu, A.; van Peteghem, C.; de Saeger, S. A direct assessment of mycotoxin biomarkers in human urine samples by liquid chromatography tandem mass spectrometry. Anal. Chim. Acta 2012, 741, 58-69. [CrossRef] [PubMed]

92. Rhouati, A.; Hayat, A.; Hernandez, D.B.; Meraihi, Z.; Munoz, R.; Marty, J.-L. Development of an automated flow-based electrochemical aptasensor for on-line detection of Ochratoxin A. Sens. Actuators B Chem. 2013, 176, 1160-1166. [CrossRef]

93. Wen, J.; Kong, W.; Hu, Y.; Wang, J.; Yang, M. Multi-mycotoxins analysis in ginger and related products by UHPLC-FLR detection and LC-MS/MS confirmation. Food Control 2014, 43, 82-87. [CrossRef]

94. Cramer, B.; Osteresch, B.; Muñoz, K.; Hillmann, H.; Sibrowski, W.; Humpf, H. Biomonitoring using dried blood spots: Detection of Ochratoxin A and its degradation product 2'R-ochratoxin A in blood from coffee drinkers. Mol. Nutr. Food Res. 2015, 59, 1837-1843. [CrossRef] [PubMed]

95. Urusov, A.V.; Zherdev, A.V.; Petrakova, A.V.; Sadykhov, E.G.; Koroleva, O.V.; Dzantiev, B.B. Rapid multiple immunoenzyme assay of mycotoxins. Toxins 2015, 7, 238-254. [CrossRef] [PubMed]

96. Todescato, F.; Antognoli, A.; Meneghello, A.; Cretaio, E.; Signorini, R.; Bozio, R. Sensitive detection of Ochratoxin A in food and drinks using metal-enhanced fluorescence. Biosens. Bioelectron. 2014, 57, 125-132. [CrossRef] [PubMed]

97. Yang, L.; Zhang, Y.; Li, R.; Lin, C.; Guo, L.; Qiu, B.; Lin, Z.; Chen, G. Electrochemiluminescence biosensor for ultrasensitive determination of Ochratoxin A in corn samples based on aptamer and hyperbranched rolling circle amplification. Biosens. Bioelectron. 2015, 70, 268-274. [CrossRef] [PubMed]

98. Pacheco, J.; Castro, M.; Machado, S.; Barroso, M.; Nouws, H.; Delerue-Matos, C. Molecularly imprinted electrochemical sensor for Ochratoxin A detection in food samples. Sens. Actuators B Chem. 2015, 215, 107-112. [CrossRef]

99. Sanzani, S.; Reverberi, M.; Fanelli, C.; Ippolito, A. Detection of Ochratoxin A using molecular beacons and Real-time PCR thermal cycler. Toxins 2015, 7, 812-820. [CrossRef] [PubMed]

100. Van Egmond, H.P. Methods for determining Ochratoxin A and other nephrotoxic mycotoxins. In Mycotoxins, Endemic Nephropathy and Urinary Tract Tumors; Castegnaro, M., Plestina, R., Dirheimer, G., Eds.; IARC Sci. Publ.: Lyon, France, 1991; Volume 115, pp. 57-70.

101. Paulsch, W.E.; van Egmond, H.P.; Schuller, P.-L. Thin layer chromatographic method for analysis and chemical confirmation of Ochratoxin A in kidneys of pigs. In Proceedings of the International IUPAC Symposium on Mycotoxins and Phycotoxins, Vienna, Austria, 1-3 September 1982; Austrian Chemical Society: Vienna, Austria, 1982; pp. 40-43.

102. Cohen, H.; Lapointe, M. Determination of Ochratoxin A in animal feed and cereal grains by liquid chromatography with fluorescence detection. J. Assoc. Off. Anal. Chem. 1986, 69, 957-959. [PubMed]

103. International Program on Chemical Safety (IPCS). Environmental Health Criteria; World Health Organization: Geneva, Switzerland, 1990; No. 105, 27.

104. Ueno, Y.; Kawamura, O.; Sugiura, Y.; Horiguchi, K.; Nakajima, M.; Yamamoto, K.; Sato, S. Use of monoclonal antibodies, enzyme-linked immunosorbent assay and immunoaffinity column chromatography to determine Ochratoxin A in porcine sera, coffee products and toxin-producing fungi. In Mycotoxins, Endemic Nephropathy and Urinary Tract Tumors; Castegnaro, M., Plestina, R., Dirheimer, G., Chernozemsky, I., Bartsch, H., Eds.; IARC Sci. Publ.: Lyon, France, 1991; Volume 115, pp. 71-75. 
105. Zimmerli, B.; Dick, R. Determination of Ochratoxin A at the ppt level in human blood, serum, milk and some foodstuffs by high performance liquid chromatography with enhanced fluorescence detection and immunoaffinity column cleanup: Methodology and Swiss data. J. Chromatogr. B Biomed. Appl. 1995, 666, 85-99. [CrossRef]

106. Prelle, A.; Spadaro, D.; Denca, A.; Garibaldi, A.; Gullino, M.L. Comparison of clean-up methods for Ochratoxin A on wine, beer, roasted coffee and chilli commercialized in Italy. Toxins 2013, 5, 1827-1844. [CrossRef] [PubMed]

107. Cao, J.; Kong, W.; Zhou, S.; Yin, L.; Wan, L.; Yang, M. Molecularly imprinted polymer-based solid phase clean-up for analysis of Ochratoxin A in beer, red wine, and grape juice. J. Sep. Sci. 2013, 36, 1291-1297. [CrossRef] [PubMed]

108. Castellari, M.; Fabbri, S.; Fabiani, A.; Amati, A.; Galassi, S. Comparison of different immunoaffinity clean-up procedures for high-performance liquid chromatographic analysis of Ochratoxin A in wines. J. Chromatogr. A 2000, 888, 129-136. [CrossRef]

109. Castegnaro, M.; Tozlovanu, M.; Wild, C.; Molinié, A.; Sylla, A.; Pfohl-Leszkowicz, A. Advantages and drawbacks of immunoaffinity columns in analysis of mycotoxins in food. Mol. Nutr. Food Res. 2006, 50, 480-487. [CrossRef] [PubMed]

110. Polisenska, I.; Pfohl-Leszkowicz, A.; Hadjeba, K.; Dohnal, V.; Jirsa, O.; Denesova, O.; Jezkova, A.; Macharackova, P. Occurrence of Ochratoxin A and citrinin in Czech cereals and comparison of two HPLC methods for Ochratoxin A detection. Food Addit. Contam. Part A Chem. Anal. Control. Expo Risk. Assess. 2010, 27, 1545-1557. [CrossRef] [PubMed]

111. Tozlovanu, M.; Pfohl-Leszkowicz, A. Ochratoxin A in roasted coffee purchased in French super market. Transfer in coffee beverage: Comparison of several methods. Toxins 2010, 2, 1928-1949. [CrossRef] [PubMed]

112. Bazin, I.; Faucet-Marquis, V.; Monje, M.; El Khoury, M.; Marty, J.; Pfohl-Leszkowicz, A. Impact of pH on the stability and the cross-reactivity of Ochratoxin A and citrinin. Toxins 2013, 5, 2324-2340. [CrossRef] [PubMed]

113. Studer-Rohr, I.; Dietrich, D.R.; Schlatter, J.; Schlatter, C. The occurrence of Ochratoxin A in coffee. Food Chem. Toxicol. 1995, 33, 341-355. [CrossRef]

114. ISO. Enviromental Management Systems—Requirements with Guidance for Use; EN ISO 45001:1989; International Organisation for Standardisation: Geneva, Switzerland, 1989.

115. ISO. General Requirements for the Competence of Testing and Calibration Laboratories; ISO/IEC 17025:2005; International Organisation for Standardisation: Geneva, Switzerland, 2005.

116. Chen, J.; Fang, Z.; Liu, J.; Zeng, L. A simple and rapid biosensor for Ochratoxin A based on a structure-switching signalling aptamer. Food Control 2012, 25, 555-560. [CrossRef]

117. Ruprich, J.; Ostry, V. Enzymo-immunological assay of the mycotoxin Ochratoxin A (in Czech). Vet. Med. 1991, 36, 245-249.

118. Ricciardi, C.; Castagna, R.; Ferrante, I.; Frascella, F.; Luigi Marasso, S.; Ricci, A.; Canavese, G.; Lorè, A.; Prelle, A.; Lodovica Gullino, M.; et al. Development of a microcantilever-based immunosensing method for mycotoxin detection. Biosens. Bioelectron. 2013, 40, 233-239. [CrossRef] [PubMed]

119. Turner, N.W.; Subrahmanyam, S.; Piletsky, S.A. Analytical methods for determination of mycotoxins: A review. Anal. Chim. Acta 2009, 632, 168-180. [CrossRef] [PubMed]

120. Frennette, C.; Paugh, R.; Tozlovanu, M.; Juzio, M.; Pfohl-Leszkowicz, A.; Manderville, R. Structure-activity relationships for the fluorescence of ochratoxin A: Insight for detection of ochratoxin A metabolites. Anal. Chim. Acta 2008, 617, 153-161. [CrossRef] [PubMed]

121. Al-Taher, F.; Banaszewski, K.; Jackson, L.; Zweingenbaum, J.; Ryu, D.; Cappozzo, J. Rapid method for the determination of multiple mycotoxins in wines and beers using a stable isotope dilution assay. J. Agric. Food Chem. 2013, 61, 2378-2384. [CrossRef] [PubMed]

122. Chu, F.S.; Chang, F.C.C.; Hinsdill, R.D. Production of antibody against Ochratoxin A. Appl. Environ. Microbiol. 1976, 31, 831-835. [PubMed]

123. Rousseau, D.M.; Slegers, G.A.; van Peteghem, C.H. Radioimmunoassay of Ochratoxin A in barley. Appl. Environ. Microbiol. 1985, 50, 529-531. [PubMed]

124. Rousseau, D.M.; Slegers, G.A.; van Peteghem, C.H. Solid phase radioimmunoassay of Ochratoxin A in serum. J. Agric. Food Chem. 1986, 34, 862-865. [CrossRef] 
125. Fukal, I. A survey of cereals, cereals products, feedstuffs and porcine kidney by radioimmunoassay. Food Addit. Contam. 1990, 7, 253-258. [CrossRef] [PubMed]

126. Fukal, I. Spontaneous occurrence of Ochratoxin A residues in Czechoslovak slaughter pigs determined by radioimmunoassay. Dtsch. Lebensm. Rundsch. 1991, 87, 316-319.

127. Meulenberg, E.P. Immunochemical methods for Ochratoxin A detection: A review. Toxins 2012, 4, $244-266$. [CrossRef] [PubMed]

128. Maragos, C.M. Analysis of mycotoxins with capillary electrophoresis. Semin. Food Anal. 1998, 3, $353-373$.

129. Böhns, B.; Seidel, V.; Lindner, W. Analysis of selected mycotoxins by capillary electrophoresis. Chromatographia 1995, 41, 631-637.

130. Corneli, S.; Maragos, C.M. Capillary electrophoresis with laser-induced fluorescence: Method for the mycotoxin Ochratoxin A. J. Agric. Food Chem. 1998, 46, 3162-3165. [CrossRef]

131. Holland, R.D.; Sepaniak, M.J. Qualitative analysis of mycotoxins using micellar electrokinetic capillary chromatography. Anal. Chem. 1993, 65, 1140-1146. [CrossRef] [PubMed]

132. Wulff, G. Molecular imprinting in cross-linked materials with the aid of molecular templates-A way towards artificial antibodies. Angew. Chem. Int. Ed. 1995, 34, 1812-1832. [CrossRef]

133. Shephard, G.S. Analytical methodology for mycotoxins: Recent advances and future challenges. In Mycotoxins and Phycotoxins Perspective at the Turn of the Millennium; De Koe, W.J., Samson, R.A., van Egmond, H.P., Gilbert, J., Sabino, M., Eds.; Publisher: W.J. de Koe, Wageningen, Netherlands, 2001.

134. Yu, J.C.C.; La, E.P.C. Molecularly imprinted polymers for Ochratoxin A extraction and analysis. Toxins 2010, 2, 1536-1553. [CrossRef] [PubMed]

135. Ngundi, M.M.; Shriver-Lake, L.C.; Moore, M.H.; Lassman, M.E.; Ligler, F.S.; Taitt, C.R. Array biosensor for detection of Ochratoxin A in cereals and beverages. Anal. Chem. 2005, 77, 148-154. [CrossRef] [PubMed]

136. Wang, Z.; Duan, N.; Hun, X.; Wu, S. Electrochemiluminescent aptamer biosensor for the determination of Ochratoxin A at a gold-nanoparticles-modified gold electrode using $N$-(aminobutyl)- $N$-ethylisoluminol as a luminescent label. Anal. Bioanal. Chem. 2010, 398, 2125-2132. [CrossRef] [PubMed]

137. Tombelli, S.; Minunni, M.; Mascini, M. Analytical applications of aptamers. Biosens. Bioelectron. 2005, 20, 2424-2434. [CrossRef] [PubMed]

138. Bonel, L.; Vidal, J.C.; Duato, P.; Castillo, J.R. An electrochemical competitive biosensor for Ochratoxin A based on a DNA biotinylated aptamer. Biosens. Bioelectron. 2011, 26, 3254-3259. [CrossRef] [PubMed]

139. Shotwell, O.L.; Hesseltine, C.W.; Goulden, M.L. Ochratoxin A: Occurrence as natural contaminant of a corn sample. Appl. Microbiol. 1969, 17, 765-766. [PubMed]

140. Scott, P.M.; van Walbeek, W.; Harwig, J.; Fennell, D.I. Occurrence of a mycotoxin, Ochratoxin A, in wheat and isolation of Ochratoxin A and citrinin producing strains of Penicillium viridicatum. Canad. J. Plant Sci. 1970, 50, 583-585. [CrossRef]

141. Scott, P.M.; van Walbeek, W.; Kennedy, B.; Anyeti, D. Mycotoxins (Ochratoxin A, citrinin, and sterigmatocystin) and toxigenic fungi in grains and agricultural products. J. Agric. Food Chem. 1972, 20, 1103-1109. [CrossRef] [PubMed]

142. Hald, B.; Krogh, P. Ochratoxin residues in bacon pigs. In Proceedings of the IUPAC: Symposium on the Control of Mycotoxins, Göteborg, Sweden, 21-22 August 1972.

143. Hunt, D.C.; Philip, L.A.; Crosby, N.T. Determination of ochratoxin A in pig's kidney using enzymatic digestion, dialysis and high-performance liquid chromatography with post-column derivatization. Analyst 1979, 104, 1171-1175. [CrossRef] [PubMed]

144. Ostry, V.; Malir, F.; Dofkova, M.; Skarkova, J.; Pfohl-Leszkowicz, A.; Ruprich, J. Ochratoxin A dietary exposure of ten population groups in the Czech Republic: Comparison with data over the world. Toxins 2015, 7, 3608-3635. [CrossRef] [PubMed]

145. European Union. Assessment of Dietary Intake of Ochratoxin A by the Population of EU Member States. Report of Experts Participating in Task 3.2.7 Reports on Tasks for Scientific Cooperation. 2002. Available online: http:/ /ec.europa.eu/food/fs/scoop/index_en.html (accessed on 7 April 2016).

146. RASFF Portal. Available online: https://webgate.ec.europa.eu/rasffwindow/portal/?event=SearchForm\& cleanSearch=1 (accessed on 11 April 2016).

147. EFSA. Opinion of the Scientific Panel on Contaminants in Food Chain on a request from the Commission related to Ochratoxin A (OTA) as undesirable substance in animal feed. EFSA J. 2004, 101, 1-36. 
148. Fuchs, R.; Peraica, M. Ochratoxin A in human kidney diseases. Food Addit. Contam. 2005, 22, 53-57. [CrossRef] [PubMed]

149. Maaroufi, K.; Achour, A.; Hammami, M.; El May, M.; Betbeder, A.; Ellouz, F.; Creppy, E.; Bacha, H. Ochratoxin A in human blood in relation to nephropathy in Tunisia. Hum. Exp. Toxicol. 1995a, 14, 609-614. [CrossRef]

150. Grosso, F.; Sa'id, S.; Mabrouk, I.; Fremy, J.; Castegnaro, M.; Jemmali, M.; Dragacci, S. New data on the occurrence of Ochratoxin A in human sera from patients affected or not by renal diseases in Tunisia. Food. Chem. Toxicol. 2003, 41, 1133-1140. [CrossRef]

151. Wafa, E.; Yahya, R.; Sobh, M.; Eraky, I.; El-Baz, M.; El-Gayar, H.; Betbeder, A.; Creppy, E. Human ochratoxicosis and nephropathy in Egypt: A preliminary study. Hum. Exp. Toxicol. 1998, 17, 124-129. [CrossRef] [PubMed]

152. World Health Organisation. Memorandum. The Endemic Nephropathy of South-eastern Europe. Bull. World Health Organ. 1965, 32, 441-448.

153. Plestina, R.; Stavljenic, A.; Ceovic, R.; Fuchs, R. Haematological features of the population of the area of Croatia, Yugoslavia, endemic for Balkan nephropathy. In Mycotoxins, Endemic Nephropathy and Urinary Tract Tumours; Castegnaro, M., Plestina, R., Dirheimer, G., Chernozemsky, I.N., Bartsch, H., Eds.; IARC: Lyon, France, 1991; pp. 43-46.

154. Stefanović, V.; Polenaković, M. Balkan nephropathy. Kidney disease beyond the Balkans? Am. J. Nephrol. 1991, 11, 1-11. [PubMed]

155. Plestina, R. Some features of Balkan endemic nephropathy. Food Chem. Toxicol. 1992, 30, 177-181. [CrossRef]

156. Akhmeteli, M.A. Epidemiology of endemic nephropathy. In Endemic Nephropathy, Proceedings of the Second International Symposium on Endemic Nephropathy, Sofia, Sofia, Bulgaria, 9-12 November 1972; Bulgarian Academy of Sciences: Sofia, Bulgaria, 1972; pp. 9-23.

157. Krogh, P. Mycotoxic porcine nephropathy-A possible model for Balkan (endemic) nephropathy. In Endemic Nephropathy, Proceedings of the Second International Symposium on Endemic Nephropathy, Sofia, Bulgaria, 9-12 November 1972; Bulgarian Academy of Sciences: Sofia, Bulgaria, 1972; pp. 266-277.

158. Ribelin, W.E.; Fukushima, K.; Still, P. The toxicity of Ochratoxin A to ruminants. Can. J. Comp. Med. 1978, 42, 172-176. [PubMed]

159. Castegnaro, M.; Bartsch, H.; Chernozemsky, I.N. Endemic nephropathy and urinary tract tumours in the Balkans. Cancer Res. 1987, 47, 3608-3609.

160. Rahimtula, A.D.; Chong, X. Alteration in calcium homeostasis as a possible cause of Ochratoxin A nephrotoxicity. In Mycotoxins, Endemic Nephropathy and Urinary Tract Tumors; Castegnaro, M., Plestina, R., Dirheimer, G., Chernozemsky, I., Bartsch, H., Eds.; IARC Sci. Publ.: Lyon, France, 1991; Volume 115, pp. 245-253.

161. Vukelic, M.; Sostaric, B.; Belicza, M. Pathomorphology of Balkan endemic nephropathy. Food Chem. Toxicol. 1992, 30, 193-200. [CrossRef]

162. Gekle, M.; Silbernagl, S. Mechanism of Ochratoxin A-induced reduction of glomerular filtration rate in rats. J. Pharmacol. Exp. Ther. 1993, 267, 316-321. [PubMed]

163. Gekle, M.; Silbernagl, S. The role of proximal tubule in Ochratoxin A nephrotoxicity in vivo: Toxodynamic and toxokinetic aspects. Renal Physiol. Biochem. 1994, 17, 40-49. [CrossRef] [PubMed]

164. Kozaczynski, W. Experimental ochratoxicosis A in chickens. Histopatological and histochemical study. Arch. Vet. Pol. 1994, 34, 205-219. [PubMed]

165. Gekle, M.; Pollock, C.A.; Silbernagl, S. Time and concentration-dependent biphasic efect of Ochratoxin A on growth of proximal tubular cells in primary culture. J. Pharmacol. Exper. Ther. 1995, 275, 397-404.

166. Gekle, M.; Silbernagl, S. Renal toxicodynamics of Ochratoxin A: A pathophysiological approach. Kidney Blood. Press Res. 1996, 19, 225-235. [CrossRef] [PubMed]

167. Kuramochi, G.; Gekle, M.; Silbernagl, S. Ochratoxin A disturbs pH homeostasis in the kidney: Increases in $\mathrm{pH}$ and HCO 3-In the tubules and vasa recta. Pflugers Arch. 1997, 434, 392-397. [CrossRef] [PubMed]

168. Atroshi, F.; Biese, I.; Saloniemi, H.; Ali-Vehmas, T.; Saari, S.; Rizzo, A.; Veijalainen, P. Significance of apoptosis and its relationship to antioxidants after Ochratoxin A administration in mice. J. Pharm. Pharm. Sci. 2000, 3, 281-291. [PubMed]

169. Di Paolo, N.; Guarnieri, A.; Loi, F.; Sacchi, G.; Mangiarotti, A.; di Paolo, M. Acute renal failure from inhalation of mycotoxins. Nephron 1993, 64, 621-625. [CrossRef] [PubMed] 
170. Godin, M.; Fillastre, J.-P.; Simon, P.; Francois, A.; le Roy, F.; Morin, J.-P. Is Ochratoxin A nephrotoxic in human beings? Adv. Nephrol. Necker Hosp. 1997, 26, 181-206. [PubMed]

171. Schwerdt, G.; Freundiger, R.; Mildenberger, S.; Silbernagl, S.; Gekle, M. The nephrotoxin Ochratoxin A induces apoptosis in cultured human proximal tubule cells. Cell Biol. Toxicol. 1999, 15, 405-415. [CrossRef] [PubMed]

172. Mally, A.; Völkel, W.; Amberg, A.; Kurz, M.; Wanek, P.; Eder, E.; Hard, G.; Dekant, W. Functional, biochemical, and pathological effects of repeated oral administration of Ochratoxin A to Rats. Chem. Res. Toxicol. 2005, 18, 1242-1252. [CrossRef] [PubMed]

173. Gekle, M.; Sauvant, C.; Schwerdt, G. Ochratoxin A at nanomolar concentrations: A signal modulator in renal cells. Mol. Nutr. Food Res. 2005, 49, 118-130. [CrossRef] [PubMed]

174. Schwerdt, G.; Holzinger, H.; Sauvant, C.; Königs, M.; Humpf, H.; Gekle, M. Long-term effects of Ochratoxin A on fibrosis and cell death in human proximal tubule or fibroblast cells in primary culture. Toxicology 2007, 232, 57-67. [CrossRef] [PubMed]

175. Jennings-Gee, J.; Tozlovanu, M.; Manderville, R.; Miller, M.; Pfohl-Leszkowicz, A.; Schwartz, G. Ochratoxin A: In utero exposure in mice induces adducts in testicular DNA. Toxins 2010, 2, 1428-1444. [CrossRef] [PubMed]

176. Limonciel, A.; Jennings, P. A review of the evidence that Ochratoxin A is an Nrf2 inhibitor: Implications for nephrotoxicity and renal carcinogenicity. Toxins 2014, 6, 371-379. [CrossRef] [PubMed]

177. Kanisawa, M.; Suzuki, S. Induction of renal and hepatic tumors in mice by Ochratoxin A, a mycotoxin. Gann 1978, 69, 599-600. [PubMed]

178. Bendele, A.M.; Carlton, W.W.; Krogh, P.; Lillehoj, E.B. Ochratoxin A carcinogenesis in the $(\mathrm{C} 57 \mathrm{~B} 1 / 6 \mathrm{~J} \times \mathrm{C} 3 \mathrm{H})$ F1 mouse. J. Nat. Cancer Int. 1985, 75, 733-742.

179. Kanisawa, M. Synergistic effect of citrinin on hepatorenal carcinogenesis of Ochratoxin A in mice. Dev. Food Sci. 1984, 7, 245-254.

180. IARC. Monographs on the Evaluation of Carcinogenic Risks to Humans: Overall Evaluations of Carcinogenicity: An Updating of IARC Monographs; IARC: Lyon, France, 1987; Volume 1-42, (Suppl. 7), pp. 1-403.

181. Boorman, G., Ed.; NTP Technical Report on the Toxicology and Carcinogenesis Studies of Ochratoxin A (CAS No. 30-47-9) in F344/N Rats (Gavage Studies), NIH Publication No. 89-2813; U.S. Department of Health and Human Services, National Institutes of Health: Research Triangle Park, NC, USA, 1989.

182. Dirheimer, G.; Creppy, E.E. Mechanism of Action of Ochratoxin A; IARC Sci. Publ.: Lyon, France, 1991; Volume 115, pp. 171-186.

183. Pfohl-Leszkowicz, A.; Chakor, K.; Creppy, E.E.; Dirheimer, G. DNA adducts formation in mice treated with Ochratoxin A. In Mycotoxins, Endemic Nephropathy and Urinary Tract Tumors; Castegnaro, M., Plestina, R., Dirheimer, G., Eds.; IARC Sci. Publ.: Lyon, France, 1991; Volume 115, pp. 245-253.

184. Pfohl-Leszkowicz, A.; Grosse, Y.; Kane, A.; Gharbi, Y.; Baudrimont, I.; Obrecht, S.; Creppy, E.E.; Dirheimer, G. Is the oxydative pathway implicated in the genotoxicity of ochratoxin A? In Human ochratoxicosis and related pathologies; John Libbey Eurotext: London Colloque INSERM, 1993; Volume 231, pp. 177-187.

185. Pfohl-Leszkowicz, A.; Grosse, Y.; Kane, A.; Creppy, E.; Dirheimer, G. Differential DNA adduct formation and disappearance in three mouse tissues after treatment with the mycotoxin Ochratoxin A. Mutat. Res. 1993, 289, 265-273. [CrossRef]

186. Pfohl-Leszkowicz, A.; Grosse, Y.; Castegnaro, M.; Petkova-Bocharova, T. Ochratoxin A Related DNA Adducts in Urinary Tract Tumours of Bulgarian Subjects; Phillips, D.H., Castegnaro, M., Bartsch, H., Eds.; IARC Sci. Publ.: Lyon, France, 1993; Volume 124, pp. 115-122.

187. Maaroufi, K.; Pfohl-Leszkowicz, A.; Achour, A.; El May, M.; Grosse, Y.; Hammami, M.; Ellouz, F.; Creppy, E.E.; Bacha, H. Genotoxicity of Ochratoxin A, relation to renal tumors. Arch. Inst. Pasteur Tunis 1994, 71, 21-31. [PubMed]

188. Azémar, B.; Pinelli, E.; Escourrou, G.; Plante, P.; Pfohl-Leszkowicz, A.P. Evidence that DNA adducts in some human kidney tumours in France are related to Ochratoxin A. Mutat. Res. 1997, 379, S157. [CrossRef]

189. Arlt, V.M.; Pfohl-Leszkowicz, A.; Cosyns, J.P.; Schmeiser, H.H. Analyses of DNA adducts formed by Ochratoxin A and aristolochic acid in patients with Chinese herbs nephropathy. Mutat. Res. 2001, 494, 143-150. [CrossRef] 
190. Faucet, V.; Pfohl-Leszkowicz, A.; Dai, J.; Castegnaro, M.; Manderville, R. Evidence for covalent DNA adduction by Ochratoxin A following chronic exposure to rat and subacute exposure to pig. Chem. Res. Toxicol. 2004, 17, 1289-1296. [CrossRef] [PubMed]

191. Pfohl-Leszkowicz, A.; Bartsch, H.; Azemar, B.; Mohr, U.; Esteve, J.; Castegnaro, M. MESNA protects rats against nephro-toxicity but not carcinogenicity induced by Ochratoxin A, implicating two separate pathways. Facta Univ. Ser. Med. Biol. 2002, 9, 57-63.

192. Petkova-Bocharova, T.; Stoichev, I.; Chernozemsky, I.; Castegnaro, M.; Pfohl-Leszkowicz, A. Formation of DNA adducts in tissues of mouse progeny through transplacental contamination and/or lactation after administration of a single dose of Ochratoxin A to the pregnant mother. Environ. Mol. Mutagen. 1998, 32, 155-162. [CrossRef]

193. Obrecht-Pflumio, S.; Dirheimer, G. In vitro DNA and dGMP adducts formation caused by Ochratoxin A. Chem. Biol. Interact. 2000, 127, 29-44. [CrossRef]

194. Obrecht-Pflumio, S.; Dirheimer, G. Horseradish peroxidase mediates DNA and deoxyguanosine 3'-monophosphate adduct formation in the presence of Ochratoxin A. Arch. Toxicol. 2001, 75, 583-590. [CrossRef] [PubMed]

195. Pfohl-Leszkowicz, A.; Castegnaro, M. Further arguments in favour of direct covalent binding of Ochratoxin A (OTA) after metabolic biotransformation. Food Addit. Contam. 2005, 22, 75-87. [CrossRef] [PubMed]

196. Gautier, J.; Holzhaeuser, D.; Markovic, J.; Gremaud, E.; Schilter, B.; Turesky, R. Oxidative damage and stress response from Ochratoxin A exposure in rats. Free Radic. Biol. Med. 2001, 30, 1089-1098. [CrossRef]

197. Petkova-Bocharova, T.; El Adlouni, C.; Faucet, V.; Pfohl-Leszkowicz, A.; Mantle, P. Analysis for DNA adducts, Ochratoxin A content and enzymes expression in kidneys of pigs exposed to mild experimental chronic ochratoxicosis. Facta Univ. Ser. Med. Biol. 2003, 10, 111-115.

198. Schwartz, G. Hypothesis: Does OTA cause induces testicular cancer. Cancer Causes Control 2002, 13, 91-100. [CrossRef] [PubMed]

199. Schwartz, G.; Faucet-Marquis, V.; Jennings-Gee, J.; Miller, M.; Manderville, R.; Pfohl-Leszkowicz, A. Prenatal exposure to Ochratoxin A causes DNA adducts in the testes of newborn mice. Scand. J. Urol. Nephrol. Suppl. 2007, 1, 217-220.

200. Schwartz, G.; Manderville, R.; Pfohl-Leszkowicz, A. Response to comments of Peter G. Mantle. Toxins 2010, 2, 2337-2339. [CrossRef]

201. Mantle, P.; Faucet-Marquis, V.; Manderville, R.; Squillaci, B.; Pfohl-Leszkowicz, A. Structures of covalent adducts between DNA and Ochratoxin A: A new factor in debate about genotoxicity and human risk assessment. Chem. Res. Toxicol. 2010, 23, 89-98. [CrossRef] [PubMed]

202. Molinié, A.; Pfohl-Leszkowicz, A. Toxic effects of co-contamination of Ochratoxin A and citrinin. Drug Metab. Rev. 2003, 35 (Suppl. 1), 77.

203. Pfohl-Leszkowicz, A.; Molinié, A.; Tozlovanu, M.; Manderville, R.A. Combined toxic effects of Ochratoxin A and citrinin, in vitro and in vivo. In Food Contaminats Mycotoxins E Food Allergen; Siantar, D.P., Trucksess, M.W., Scott, P.M., Herman, E.M., Eds.; ACS Publication: Washington, DC, USA, 2008; Volume 1001, pp. 56-80.

204. Mally, A.; Zepnik, H.; Wanek, P.; Eder, E.; Dingley, K.; Ihmels, H.; Völkel, W.; Dekant, W. Ochratoxin A: Lack of formation of covalent DNA adducts. Chem. Res. Toxicol. 2004, 17, 234-242. [CrossRef] [PubMed]

205. Lock, E.; Hard, G. Chemically induced renal tubule tumors in the laboratory rat and mouse: Review of the NCI/NTP database and categorization of renal carcinogens based on mechanistic information. Crit. Rev. Toxicol. 2004, 34, 211-299. [CrossRef] [PubMed]

206. Mantle, P.; Kulinskaya, E.; Nestler, S. Renal tumourigenesis in male rats in response to chronic dietary Ochratoxin A. Food Addit. Contam. 2005, 22, 58-64. [CrossRef] [PubMed]

207. Mantle, P.; Kulinskaya, E. Lifetime, low-dose Ochratoxin A dietary study on renal carcinogenesis in male Fischer rats. Food Addit. Contam. Part A Chem. Anal. Control. Expo Risk. Assess. 2010, 27, 1566-1573. [CrossRef] [PubMed]

208. Manderville, R.A. Case for the genotoxicity of Ochratoxin A by bioactivation and covalent DNA adduction. Chem. Res. Toxicol. 2005, 18, 1091-1097. [CrossRef] [PubMed]

209. Pfohl-Leszkowicz, A.; Manderville, R. An update on direct genotoxicity as a molecular mechanism of Ochratoxin A carcinogenicity. Chem. Res. Toxicol. 2012, 25, 252-262. [CrossRef] [PubMed]

210. Zeljezic, D.; Domijan, A.; Peraica, M. DNA damage by Ochratoxin A in rat kidney assessed by the alkaline comet assay. Braz. J. Med. Biol. Res. 2006, 39, 1563-1568. [CrossRef] [PubMed] 
211. Brown, A.; Odell, E.; Mantle, P. DNA ploidy distribution in renal tumours induced in male rats by dietary Ochratoxin A. Exp. Toxicol. Pathol. 2007, 59, 85-95. [CrossRef] [PubMed]

212. Palma, N.; Cinelli, S.; Sapora, O.; Wilson, S.; Dogliotti, E. Ochratoxin A-induced mutagenesis in mammalian cells is consistent with the production of oxidative stress. Chem. Res. Toxicol. 2007, 20, 1031-1037. [CrossRef] [PubMed]

213. Delatour, T.; Mally, A.; Richoz, J.; Özden, S.; Dekant, W.; Ihmels, H.; Otto, D.; Gasparutto, D.; Marin-Kuan, M.; Schilter, B.; et al. Absence of 2'-deoxyguanosine-carbon 8-bound Ochratoxin A adduct in rat kidney DNA monitored by isotope dilution LC-MS/MS. Mol. Nutr. Food Res. 2008, 52, 472-482. [CrossRef] [PubMed]

214. Manderville, R.; Pfohl-Leszkowicz, A. Bioactivation and DNA adduction as a rationale for Ochratoxin A carcinogenesis. World Mycotoxin J. 2008, 1, 357-367. [CrossRef]

215. Mally, A.; Dekant, W. Mycotoxins and the kidney: Modes of action for renal tumor formation by Ochratoxin A in rodents. Mol. Nutr. Food Res. 2009, 53, 467-478. [CrossRef] [PubMed]

216. Stoev, S. Studies on carcinogenic and toxic effects of Ochratoxin A in chicks. Toxins 2010, 2, 649-664. [CrossRef] [PubMed]

217. Hibi, D.; Suzuki, Y.; Ishii, Y.; Jin, M.; Watanabe, M.; Sugita-Konishi, Y.; Yanai, T.; Nohmi, T.; Nishikawa, A.; Umemura, T. Site-specific in vivo mutagenicity in the kidney of gpt delta rats given a carcinogenic dose of Ochratoxin A. Toxicol. Sci. 2011, 122, 406-414. [CrossRef] [PubMed]

218. Akman, S.; Adams, M.; Case, D.; Park, G.; Manderville, R. Mutagenicity of Ochratoxin A and its hydroquinone metabolite in the SupF gene of the mutation reporter plasmid Ps189. Toxins 2012, 4, 267-280. [CrossRef] [PubMed]

219. Calin, G.A.; Sevignani, C.; Dumitru, C.D.; Hyslop, T.; Noch, S.; Yendamuri, S.; Schimizu, M.; Rattan, S.; Bullrich, F.; Negrini, M.; et al. Frequent deletions and down-regulation of micro-RNA genes miR15 and miR16 at 13q14 in chronic lymphotic leukemia. Proc. Natl. Acad. Sci. USA 2002, 99, 15524-15529. [CrossRef] [PubMed]

220. Calin, G.A.; Sevignani, C.; Dumitru, C.D.; Hyslop, T.; Noch, S.; Yendamuri, S.; Schimizu, M.; Rattan, S.; Bullrich, F.; Negrini, M.; et al. Human microRNA genes are frequently located at fragile sites and genomic regions involved in cancers. Proc. Natl. Acad. Sci. USA 2004, 101, 2999-3004. [CrossRef] [PubMed]

221. Stachurska, A.; Ciesla, M.; Kozakowska, M.; Wolffram, S.; Boesch-Saadatmandi, Ch.; Rimbach, G.; Jozkowicz, A.; Dulak, J.; Loboda, A. Cross-talk between microRNAs, nuclear factor E2-related factor 2, and heme oxygenase-1 in ochratoxin A-induced toxic effects in renal proximal tubular epithelial cells. Mol. Nutr. Food Res. 2013, 57, 504-515. [CrossRef] [PubMed]

222. Hennemeier, I.; Humpf, H.U.; Gekle, M.; Schwerdt, G. Role of microRNA-29b in the ochratoxin A-induced enhanced collagen formation in human kidney cells. Toxicology 2014, 324, 116-122. [CrossRef] [PubMed]

223. Gonzalez-Arias, C.; Benitez-Trinidad, A.; Sordo, M.; Robledo-Marenco, L.; Medina-Díaz, I.; Barrón-Vivanco, B.; Marín, S.; Sanchis, V.; Ramos, A.; Rojas-García, A. Low doses of Ochratoxin A induce micronucleus formation and delay DNA repair in human lymphocytes. Food. Chem. Toxicol. 2014, 74, 249-254. [CrossRef] [PubMed]

224. Qi, X.; Yu, T.; Zhu, L.; Gao, J.; He, X.; Huang, K.; Luo, Y.; Xu, W. Ochratoxin A induces rat renal carcinogenicity with limited induction of oxidative stress responses. Toxicol. Appl. Pharmacol. 2014, 280, 543-549. [CrossRef] [PubMed]

225. IARC. Monographs on the Evaluation of Carcinogenic Risks of Chemicals to Man: Some Naturally Occurring Substances; IARC: Lyon, France, 1976; Volume 10, pp. 191-197.

226. IARC. Monographs on the Evaluation of Carcinogenic Risks of Chemicals to Humans: Some Food Additives, Feed Additives and Naturally Occurring Substances; IARC: Lyon, France, 1983; Volume 31, pp. 191-206.

227. IARC. Available online: http://monographs.iarc.fr/ENG/Preamble/CurrentPreamble.pdf (accessed on 10 April 2016).

228. Degen, G. Tools for investigating workplace-related risks from mycotoxin exposure. World Mycotoxin J. 2011, 4, 315-327. [CrossRef]

229. Hult, K.; Plestina, R.; Habazin-Novak, V.; Radic, B.; Ceovic, S. Ochratoxin A in human blood and Balkan Endemic Nephropathy. Arch Toxicol. 1982, 51, 313-321. [CrossRef]

230. Baldwin, T.; Riley, R.; Zitomer, N.; Voss, K.; Coulombe, R., Jr.; Pestka, J.; Williams, D.; Glenn, A. The current state of mycotoxin biomarker development in humans and animals and the potential for application to plant systems. World Mycotoxin J. 2011, 4, 257-270. [CrossRef] 
231. Turner, P.; Flannery, B.; Isitt, C.; Ali, M.; Pestka, J. The role of biomarkers in evaluating human health concerns from fungal contaminants in food. Nutr. Res. Rev. 2012, 25, 162-179. [CrossRef] [PubMed]

232. Duarte, S.; Pena, A.; Lino, C. Human Ochratoxin A biomarkers-from exposure to effect. Crit. Rev. Toxicol. 2011, 41, 187-212. [CrossRef] [PubMed]

233. Soto, J.; Ruiz, M.; Manyes, L.; Juan-García, A. Blood, breast milk and urine: Potential biomarkers of exposure and estimated daily intake of Ochratoxin A: A review. Food Addit. Contam. Part A Chem. Anal. Control. Expo Risk. Assess. 2015, 1-16. [CrossRef] [PubMed]

234. Hult, K.; Hokby, E.; Gatenbeck, S.; Plestina, R.; Ceovic, S. Ochratoxin A and Balkan endemic nephropathy. IV. Occurrence of Ochratoxin A in humans. Chem. Rundschau 1979, 35, 32-33.

235. Scott, P. Biomarkers of human exposure to Ochratoxin A. Food Addit. Contam. 2005, 22, 99-107. [CrossRef] [PubMed]

236. Gilbert, J.; Brereton, P.; MacDonald, S. Assessment of dietary exposure to Ochratoxin A in the UK using a duplicate diet approach and analysis of urine and plasma samples. Food Addit. Contam. 2001, 18, 1088-1093. [CrossRef] [PubMed]

237. Castegnaro, M.; Canadas, D.; Vrabcheva, T.; Petkova-Bocharova, T.; Chernozemsky, I.; Pfohl-Leszkowicz, A. Balkan Endemic Nephropathy: Role of ochratoxins A through biomarkers. Mol. Nutr. Food Res. 2006b, 50, 519-529. [CrossRef] [PubMed]

238. Pfohl-Leszkowicz, A.; Tozlovanu, M.; Stepanovic, J.; Stefanovic, V.; Manderville, R.; Castegnaro, M. Comparative genotoxicity of Ochratoxin A and aristolochic acid in human kidney cells: Interpretation of ongoing analyses of food, blood, urine and kidney tissue from Serbia. Coll. Antropol. Suppl. 2006, 30, 1-17.

239. Muñoz, K.; Blaszkewicz, M.; Campos, V.; Vega, M.; Degen, G. Exposure of infants to Ochratoxin A with breast milk. Arch. Toxicol. 2014, 88, 837-846. [CrossRef] [PubMed]

240. Ali, N.; Blaszkewicz, M.; Manirujjaman, M.; Perveen, R.; Nahid, A.; Mahmood, S.; Rahman, M.; Hossain, K.; Degen, G. Biomonitoring of Ochratoxin A in blood plasma and exposure assessment of adult students in Bangladesh. Mol. Nutr. Food Res. 2014, 58, 2219-2225. [CrossRef] [PubMed]

241. Hald, B. Ochratoxin A in human blood in European countries. In Mycotoxins, Endemic Nephropathy and Urinary Tract Tumours; Castegnaro, M., Plestina, R., Dirheimer, G., Chernozemsky, I.N., Bartsch, H., Eds.; IARC Scientific Publications: Lyon, France, 1991; Volume 115, pp. 159-164.

242. Bauer, J.; Gareis, M. Ochratoxin A in the food chain (Ger). J. Vet. Med. 1987, B34, 613-627. [CrossRef]

243. Petkova-Bocharova, T.; Chernozemsky, I.; Castegnaro, M. Ochratoxin A in human blood in relation to Balkan Endemic Nephropathy and urinary system tumours in Bulgaria. Food Addit. Contam. 1988, 5, $299-301$. [CrossRef] [PubMed]

244. Petkova-Bocharova, T.; Castegnaro, M. Ochratoxin A in human blood in relation to endemic nephropathy and urinary tract tumors in Bulgaria. In Mycotoxins, Endemic Nephropathy and Urinary Tract Tumours; Castegnaro, M., Plestina, R., Dirheimer, G., Chernozemsky, I.N., Bartsch, H., Eds.; IARC Scientific Publications: Lyon, France, 1991; Volume 115, pp. 159-164.

245. Golinski, P.; Grabatkiewicz-Szczenasna, J.; Chelkowski, J.; Hult, K.; Kostecki, M. Possible sources of Ochratoxin A in human blood. In Mycotoxins, Endemic Nephropathy and Urinary Tract Tumours; Castegnaro, M., Plestina, R., Dirheimer, G., Chernozemsky, I.N., Bartsch, H., Eds.; IARC Scientific Publications: Lyon, France, 1991; Volume 115, pp. 153-157.

246. Fuchs, R.; Radic, B.; Ceovic, S.; Sostaric, B.; Hult, K. Human Exposure to Ochratoxin A; IARC Sci Publ.: Lyon, France, 1991; Volume 115, pp. 131-134.

247. Hadlok, R.M.; Wagner, G. Vorkommen von Ochratoxin A beim menschen in Deutschland. Fleischwirtsch 1993, 73, 1079-1080.

248. Fukal, L.; Reisnerova, H. Monitoring of aflatoxins and Ochratoxin A in Czechoslovak human sera by immunoassay. Bull. Environ. Contam. Toxicol. 1990, 44, 345-349. [CrossRef] [PubMed]

249. Creppy, E.E.; Betbeder, A.M.; Gharbi, A.; Counord, J.; Castegnaro, M.; Bartsch, H.; Moncharmont, P.; Fouillet, B.; Chambon, P.; Dirheimer, G. Human Ochratoxicosis in France; IARC Sci. Publ.: Lyon, France, 1991; Volume 115, pp. 131-134.

250. Ruprich, J.; Ostry, V. Health risk assessment of the mycotoxin Ochratoxin A to humans: Czech Republic-Brno-1991/92. Cent. Eur. J. Public Health 1993, 1, 86-93. [PubMed] 
251. Creppy, E.E.; Castegnaro, M.; Grosse, Y.; Meriaux, J.; Moncharmont, P.; Waller, C. Etude de l'ochratoxicose humaine dans trois regions de France: Alsace, Aquitaine, et region Rhone-Alpes. In Human Ochratoxicosis and Its Pathologies; Creppy, E.E., Castegnaro, M., Dirheimer, G., Eds.; Colloque INSERM/John Libbey Eurotext: London, UK, 1993; Volume 231, pp. 147-158.

252. Benford, D.; Boyle, C.; Dekant, W.; Fuchs, R.; Gaylor, D.W.; Hard, G.; McGregor, D.B.; Pitt, J.I.; Plestina, R.; Shepard, G.; et al. Ochratoxin A. In Safety Evaluation of Certain Mycotoxins in Food, Proceedings of the 56th Meeting of the Joint FAO/WHO Expert Committee on Food Additives (JECFA), Geneva, 6-15 February, 2001; World Health Organization: Geneva, Switzerland, 2001; Volume 47, pp. 281-387.

253. Breitholtz-Emanuelsson, A.; Minervini, F.; Hult, K.; Visconti, A. Ochratoxin A in human serum samples collected in southern Italy from healthy individuals and individuals suffering from different kidney disorders. Nat. Toxins 1994, 2, 366-370. [PubMed]

254. Kovacs, F.; Sandor, G.; Vanyi, A.; Domany, S.; Zomborszky-Kovacs, M. Detection of Ochratoxin A in human blood and colostrum. Acta Vet. Hung. 1995, 43, 393-400. [PubMed]

255. Palli, D.; Miraglia, M.; Saieva, C.; Masala, G.; Cava, E.; Colatosti, M.; Corsi, A.M.; Russo, A.; Brera, C. Serum levels of Ochratoxin A in healthy adults in Tuscany: Correlation with individual characteristics and between repeat measurements. Cancer Epidemiol. Biomark. Prev. 1999, 8, 265-269.

256. Solti, L.; Salamon, F.; Barna-Vetro, I.; Gyongyosi, A.; Szabo, E.; Wolfling, A. Ochratoxin A content of human sera determined by a sensitive ELISA. J. Anal. Toxicol. 1997, 21, 44-48. [CrossRef] [PubMed]

257. Malir, F.; Cerna, M.; Severa, J.; Jergeova, Z. Ochratoxin A-Toxicological importance, exposure of humans and health risk. Hygiena 1998, 43, 49-62.

258. Malir, F.; Brndiar, M.; Roubal, T.; Severa, J.; Fixa, P.; Kacerovsky, J.; Zahradnik, J.; Osterreicher, J.; Knizek, J.; Cerna, M. A Study of the accumulation of Ochratoxin A in patients with Chronic Renal Insufficiency (CHRI) in the Czech Republic. Mycotoxin Res. 2001, 17, 39-44.

259. Malir, F.; Roubal, T.; Brndiar, M.; Osterreicher, J.; Severa, J.; Knizek, J.; Kacerovsky, J.; Tmejova, M.; Betbeder, A.; Baudrimont, I.; et al. Ochratoxin A in the Czech Republic. Toxin Rev. 2001b, 20, 261-274. [CrossRef]

260. Malir, F.; Ostry, V.; Grosse, Y.; Roubal, T.; Skarkova, J.; Ruprich, J. Monitoring the mycotoxins in food and their biomarkers in the Czech Republic. Mol. Nutr. Food Res. 2006, 50, 513-518. [CrossRef] [PubMed]

261. Jimenez, A.; Lopez de Cerain, A.; Gonzalez-Peñas, E.; Bello, J.; Betbeder, A.; Creppy, E. Exposure to Ochratoxin A in Europe: Comparison with a region of northern Spain. Toxin Rev. 1998, 17, 479-491. [CrossRef]

262. Perez de Obanos, A.; Lopez de Cerain, A.; Jimenez, A.M.; Gonzales-Penas, E.; Bello, J. Ochratoxin A in human plasma: New data of exposition in Spain. Rev Toxicol. 2001, 18, 19-23.

263. Tapai, K.; Teren, J.; Mesterhazy, A. Ochratoxin A in the sera of blood donors and ill persons. Cereal Res. Commun. 1997, 25, 307-308.

264. Domijan, A.M.; Peraica, M.; Fuchs, R.; Lucic, A.; Radic, B.; Balija, M.; Bosanac, I.; Grgicevic, D. Ochratoxin A in blood of healthy population in Zagreb. Arh. Hig. Rada Toksikol. 1999, 50, 263-271. [PubMed]

265. Peraica, M.; Domijan, A.; Fuchs, R.; Lucić, A.; Radić, B. The Occurrence of Ochratoxin A in blood in general population of Croatia. Toxicol. Lett. 1999, 110, 105-112. [CrossRef]

266. Peraica, M.; Domijan, A.; Matašin, M.; Lucić, A.; Radić, B.; Delaš, F.; Horvat, M.; Bosanac, I.; Balija, M.; Grgičević, D. Variations of Ochratoxin A concentration in the blood of healthy populations in some Croatian cities. Arch. Toxicol. 2001, 75, 410-414. [CrossRef] [PubMed]

267. Thuvander, A.; Paulsen, J.; Axberg, K.; Johansson, N.; Vidnes, A.; Enghardt-Barbieri, H.; Trygg, K.; Lund-Larsen, K.; Jahrl, S.; Widenfalk, A.; et al. Levels of Ochratoxin A in blood from Norwegian and Swedish blood donors and their possible correlation with food consumption. Food. Chem. Toxicol. 2001, 39, 1145-1151. [CrossRef]

268. Rösner, H.; Rohrmann, B.; Peiker, G. Ochratoxin A in human serum. Arch. Lebensm. 2000, 51, $104-107$.

269. MacDonald, S.J.; Langton, S.; Brereton, P.A. Assessment of human exposure to Ochratoxin A in the UK-relationship between dietary intake and plasma and urine levels. In Mycotoxins and Phycotoxins in Perspective at the Turn of the Millennium; De Koe, W.J., Samson, R.A., van Egmond, H.P., Gilbert, J., Sabino, M., Eds.; IUPAC: Wageningen, The Netherlands, 2001; Volume 1, pp. 181-188.

270. Skaug, M.A. Levels of Ochratoxin A and IgG against conidia of Penicillium verrucosum in blood samples from healthy farm workers. Ann. Agric. Environ. Med. 2003, 10, 73-77. [CrossRef] 
271. Lino, C.; Baeta, M.; Henri, M.; Dinis, A.; Pena, A.; Silveira, M. Levels of Ochratoxin A in serum from urban and rural Portuguese populations and estimation of exposure degree. Food. Chem. Toxicol. 2008, 46, 879-885. [CrossRef] [PubMed]

272. Grajewski, J.; Jarzemski, P.; Twaruzek, M.; Kuzminska, K.; Trepala, M. The level of Ochratoxin A in patients after nephrectomy. Mycotoxin Res. 2007, 23, 22-26. [CrossRef] [PubMed]

273. Malir, F.; Roubal, T.; Brndiar, M.; Kacerovsky, J.; Pacovsky, J.; Moravek, P.; Melichar, B.; Malirova, E.; Cerna, M. The monitoring mycotoxins and their potential impact on human health: Ochratoxin A. (in Czech). In Proceedings of the 4. Seminary with International Participation. Mykotoxíny 2008, Prague, Czech Republic, 9-10 October 2008.

274. Medina, Á.; Mateo, E.; Roig, R.; Blanquer, A.; Jiménez, M. Ochratoxin A levels in the plasma of healthy blood donors from Valencia and estimation of exposure degree: Comparison with previous national Spanish data. Food Addit. Contam. Part A Chem. Anal. Control. Expo Risk. Assess. 2010, 27, 1273-1284. [CrossRef] [PubMed]

275. Coronel, M.; Sanchis, V.; Ramos, A.; Marin, S. Assessment of the exposure to Ochratoxin A in the province of Lleida, Spain. Food. Chem. Toxicol. 2009, 47, 2847-2852. [CrossRef] [PubMed]

276. Muñoz, K.; Blaszkewicz, M.; Degen, G. Simultaneous analysis of Ochratoxin A and its major metabolite ochratoxin alpha in plasma and urine for an advanced biomonitoring of the mycotoxin. J. Chromatogr. B Biomed. Appl. 2010, 878, 2623-2629. [CrossRef] [PubMed]

277. Coronel, M.; Sanchis, V.; Ramos, A.; Marin, S. Ochratoxin A in adult population of Lleida, Spain: Presence in blood plasma and consumption in different regions and seasons. Food. Chem. Toxicol. 2011a, 49, 2697-2705. [CrossRef] [PubMed]

278. Di Giuseppe, R.; Bertuzzi, T.; Rossi, F.; Rastelli, S.; Mulazzi, A.; Capraro, J.; de Curtis, A.; Iacoviello, L.; Pietri, A. Plasma Ochratoxin A levels, food consumption, and risk biomarkers of a representative sample of men and women from the Molise region in Italy. Eur. J. Nutr. 2011, 51, 851-860. [CrossRef] [PubMed]

279. Malir, F.; Ostry, V.; Dofkova, M.; Roubal, T.; Dvorak, V.; Dohnal, V. Ochratoxin A levels in blood serum of Czech women in the first trimester of pregnancy and its correspondence with dietary intake of the mycotoxin contaminant. Biomarkers 2013, 18, 673-678. [CrossRef] [PubMed]

280. Dohnal, V.; Dvořák, V.; Malíř, F.; Ostrý, V.; Roubal, T. A comparison of ELISA and HPLC methods for determination of Ochratoxin A in human blood serum in the Czech Republic. Food. Chem. Toxicol. 2013, 62, 427-431. [CrossRef] [PubMed]

281. Khalef, A.; Zidane, C.; Charef, A.; Gharbi, A.; Tadjerouna, M.; Betbeder, A.M.; Creppy, E.E. Ochratoxicoses humaines en Algerie. In Human Ochratoxicosis and Its Pathologies; Creppy, E., Castegnaro, M., Dirheimer, G., Eds.; John Libbey Eurotext: Paris, France, 1993; Volume 231, pp. 123-127.

282. Maaroufi, K.; Achour, A.; Betbeder, A.; Hammami, M.; Ellouz, F.; Creppy, E.; Bacha, H. Foodstuffs and human blood contamination by the mycotoxin Ochratoxin A: Correlation with chronic interstitial nephropathy in Tunisia. Arch. Toxicol. 1995, 69, 552-558. [CrossRef] [PubMed]

283. Jonsyn, F. Intake of aflatoxins and ochratoxins by infants in Sierra Leone: Possible effects on the general health of these hildren. J. Nutr. Environ. Med. 1999, 9, 15-22. [CrossRef]

284. Filali, A.; Betbeder, A.; Baudrimont, I.; Benayada, A.; Soulaymani, R.; Creppy, E. Ochratoxin A in human plasma in Morocco: A preliminary survey. Hum. Exp. Toxicol. 2002, 21, 241-245. [CrossRef] [PubMed]

285. Abid, S.; Hassen, W.; Achour, A.; Skhiri, H.; Maaroufi, K.; Ellouz, F.; Creppy, E.; Bacha, H. Ochratoxin A and human chronic nephropathy in Tunisia: Is the situation endemic? Hum. Exp. Toxicol. 2003, 22, 77-84. [CrossRef] [PubMed]

286. Hassen, W.; Abid, S.; Achour, A.; Creppy, E.; Bacha, H. Ochratoxin A and $\beta 2$-microglobulinuria in healthy individuals and in Chronic Interstitial Nephropathy patients in the centre of Tunisia: A hot spot of Ochratoxin A exposure. Toxicology 2004, 199, 185-193. [CrossRef] [PubMed]

287. Sangare-Tigori, B.; Moukha, S.; Kouadio, J.; Dano, D.; Betbeder, A.; Achour, A.; Creppy, E. Ochratoxin A in human blood in Abidjan, Côte D'ivoire. Toxicon 2006, 47, 894-900. [CrossRef] [PubMed]

288. Hmaissia Khlifa, K.; Ghali, R.; Mezigh, C.; Aouni, Z.; Ghorbel, H.; Harrzallah, K.; Machgoul, S.; Hedhili, A. Serum levels of Ochratoxin A in healthy subjects and in nephropathic patients in Tunisia. Ann. Biol. Clin. (Paris) 2008, 66, 631-636. [PubMed]

289. Karima, H.; Ridha, G.; Zied, A.; Chekib, M.; Salem, M.; Abderrazek, H. Estimation of Ochratoxin A in human blood of healthy Tunisian population. Exp. Toxicol. Pathol. 2010, 62, 539-542. [CrossRef] [PubMed] 
290. Zaied, C.; Bouaziz, C.; Azizi, I.; Bensassi, F.; Chour, A.; Bacha, H.; Abid, S. Presence of Ochratoxin A in Tunisian blood nephropathy patients. Exposure level to OTA. Exp. Toxicol. Pathol. 2011, 63, 613-618. [CrossRef] [PubMed]

291. Hmaissia Khlifa, K.; Ghali, R.; Mazigh, C.; Aouni, Z.; Machgoul, S.; Hedhili, A. Ochratoxin A levels in human serum and foods from nephropathy patients in Tunisia: Where are you now? Exp. Toxicol. Pathol. 2012, 64, 509-512. [CrossRef] [PubMed]

292. Ueno, Y.; Maki, S.; Lin, J.; Furuya, M.; Sugiura, Y.; Kawamura, O. A 4-year study of plasma Ochratoxin $\mathrm{A}$ in a selected population in Tokyo by immunoassay and immunoaffinity column-linked HPLC. Food. Chem. Toxicol. 1998, 36, 445-449. [CrossRef]

293. Assaf, H.; Betbeder, A.; Creppy, E.; Pallardy, M.; Azouri, H. Ochratoxin A levels in human plasma and foods in Lebanon. Hum. Exp. Toxicol. 2004, 23, 495-501. [CrossRef] [PubMed]

294. Aslam, M.; Beg, A.; Blaszkewicz, M.; Degen, G.; Golka, K. Ochratoxin A blood concentration in healthy subjects and bladder cancer cases from Pakistan. Toxicol. Lett. 2006, 164, S280. [CrossRef]

295. Özçelik, N.; Koşar, A.; Soysal, D. Ochratoxin A in human serum samples collected in Isparta-Turkey from healthy Individuals and individuals suffering from different urinary disorders. Toxicol. Lett. 2001, 121, 9-13. [CrossRef]

296. Erkekoğlu, P.; Sabuncuoğlu, S.; Aydın, S.; Şahin, G.; Giray, B. Determination of seasonal variations in serum Ochratoxin A levels in healthy population living in some regions of Turkey by Enzyme-Linked Immunosorbent assay. Toxicon 2010, 55, 507-513. [CrossRef] [PubMed]

297. Sabuncuoglu, S.; Erkekoglu, P.; Aydin, S.; Şahin, G.; Kocer-Gumusel, B. The effects of season and gender on the serum aflatoxins and Ochratoxin A levels of healthy adult subjects from the Central Anatolia Region, Turkey. Eur. J. Nutr. 2014, 54, 629-638. [CrossRef] [PubMed]

298. Kuiper-Goodman, T.; Ominski, K.; Marquardt, R.R.; Malcom, S.; McMullen, E.; Lombaert, G.A.; Morton, T. Estimating human exposure to Ochratoxin A in Canada. In Human Ochratoxicosis and Its Pathologies; Creppy, E.E., Castegnaro, M., Dirheimer, G., Eds.; INSERM/John Libbey Eurotext: Montrouge, France, 1993; pp. 167-174.

299. Scott, P.; Kanhere, S.; Lau, B.; Levvis, D.; Hayward, S.; Ryan, J.; Kuiper-Goodman, T. Survey of Canadian human blood plasma for Ochratoxin A. Food Addit. Contam. 1998, 15, 555-562. [CrossRef] [PubMed]

300. Muñoz, K.; Vega, M.; Rios, G.; Muñoz, S.; Madariaga, R. Preliminary study of Ochratoxin A in human plasma in agricultural zones of Chile and its relation to food consumption. Food. Chem. Toxicol. 2006, 44, 1884-1889. [CrossRef] [PubMed]

301. Guzman, E.M.; Guerrero, F.A.; Chaves, J.A. Ochratoxin A in human plasma and coffee from Costa Rica by ELISA. Arch. Latinoam. Nutr. 2007, 57, 168-172. [PubMed]

302. Pacin, A.; Ciancio Bovier, E.; Motta, E.; Resnik, S.; Villa, D.; Olsen, M. Survey of Argentinean human plasma for Ochratoxin A. Food Addit. Contam. Part A Chem. Anal. Control. Expo Risk. Assess. 2008, 25, 635-641. [CrossRef] [PubMed]

303. Castegnaro, M.; Maru, V.; Petkova-Bocharova, T.; Nikolov, I.; Bartsch, H. Concentrations of Ochratoxin A in the urine of endemic nephropathy patients and controls in Bulgaria: Lack of detection of 4-hydroxyochratoxin A. In Mycotoxins, Endemic Nephropathy and Urinary Tract Tumours; Castegnaro, M., Plestina, R., Dirheimer, G., Chernozemsky, I.N., Bartsch, H., Eds.; IARC Scientific Publications: Lyon, France, 1991; Volume 115, pp. 165-169.

304. Ostry, V.; Skarkova, J.; Kavrik, R.; Ruprich, J. An occurrence of Ochratoxin A and aflatoxin M1 biomarkers in human urine. In Proceedings of the 32th Mycotoxin Workshop, Lyngby, Denmark, 14-16 June, 2010.

305. Ostry, V.; Skarkova, J.; Malir, F.; Ruprich, J. An occurrence of Ochratoxin A, a biomarker of dietary exposure, in human biological materials. In Proceedings of the 6. Seminary with International Participation. Mykotoxíny 2010, Prague, VSCHT, 14-15 October 2010.

306. Warth, B.; Sulyok, M.; Berthiller, F.; Schuhmacher, R.; Krska, R. New insights into the human metabolism of the fusarium mycotoxins deoxynivalenol and zearalenone. Toxicol. Lett. 2013, 220, 88-94. [CrossRef] [PubMed]

307. Warth, B.; Sulyok, M.; Krska, R. LC-MS/MS-based multibiomarker approaches for the assessment of human exposure to mycotoxins. Anal. Bioanal. Chem. 2013, 405, 5687-5695. [CrossRef] [PubMed] 
308. Warth, B.; Sulyok, M.; Fruhmann, P.; Mikula, H.; Berthiller, F.; Schuhmacher, R.; Hametner, C.; Abia, W.; Adam, G.; Fröhlich, J.; et al. Development and validation of a rapid multi-biomarker liquid chromatography/tandem mass spectrometry method to assess human exposure to mycotoxins. Rapid Commun. Mass Spectrom. 2012, 26, 1533-1540. [CrossRef] [PubMed]

309. Ediage, N.E.; Diana Di Mavungu, J.; Song, S.; Sioen, I.; de Saeger, S. Multimycotoxin analysis in urines to assess infant exposure: A case study in Cameroon. Environ. Int. 2013, 57-58, 50-59. [CrossRef] [PubMed]

310. Jonsyn, F.E. Seasonal variation in exposure frequency and concentration levels of aflatoxins and ochratoxins in urine samples of boys and girls. Mycopathologia 2000, 152, 35-40. [CrossRef]

311. Domijan, A.; Peraica, M.; Miletić-Medved, M.; Lucić, A.; Fuchs, R. Two different clean-up procedures for liquid chromatographic determination of Ochratoxin A in urine. J. Chromatogr. B Biomed. Appl. 2003, 798, 317-321. [CrossRef]

312. Fazekas, B.; Tar, A.; Kovács, M. Ochratoxin A content of urine samples of healthy humans in Hungary. Acta Vet. Hung. 2005, 53, 35-44. [CrossRef] [PubMed]

313. Pena, A.; Seifrtová, M.; Lino, C.; Silveira, I.; Solich, P. Estimation of Ochratoxin A in Portuguese population: New data on the occurrence in human urine by high performance liquid chromatography with fluorescence detection. Food. Chem. Toxicol. 2006, 44, 1449-1454. [CrossRef] [PubMed]

314. Manique, R.; Pena, A.; Lino, C.; Moltó, J.; Mañes, J. Ochratoxin A in the morning and afternoon portions of urine from Coimbra and Valencian populations. Toxicon 2008, 51, 1281-1287. [CrossRef] [PubMed]

315. Duarte, S.; Bento, J.; Pena, A.; Lino, C. Ochratoxin A exposure assessment of the inhabitants of Lisbon during winter 2007/2008 through bread and urine analysis. Food Addit. Contam. Part A Chem. Anal. Control. Expo Risk. Assess. 2009, 26, 1411-1420. [CrossRef] [PubMed]

316. Domijan, A.; Peraica, M.; Markov, K.; Fuchs, R. Urine Ochratoxin A and sphinganine/sphingosine ratio in residents of the Endemic nephropathy area in Croatia. Arch. Ind. Hyg. Toxicol. 2009, 60, 387-393. [CrossRef] [PubMed]

317. Duarte, S.; Bento, J.; Pena, A.; Lino, C.; Delerue-Matos, C.; Oliva-Teles, T.; Morais, S.; Correia, M.; Oliveira, M.; Alves, M.; et al. Monitoring of Ochratoxin A exposure of the Portuguese population through a nationwide urine survey-Winter 2007. Sci. Total Environ. 2010, 408, 1195-1198. [CrossRef] [PubMed]

318. Akdemir, C.; Ulker, O.; Basaran, A.; Ozkaya, S.; Karakaya, A. Estimation of Ochratoxin A in some Turkish populations: An analysis in urine as a simple, sensitive and reliable biomarker. Food. Chem. Toxicol. 2010, 48, 877-882. [CrossRef] [PubMed]

319. Coronel, M.; Marin, S.; Tarragó, M.; Cano-Sancho, G.; Ramos, A.; Sanchis, V. Ochratoxin A and its metabolite Ochratoxin Alpha in urine and assessment of the exposure of inhabitants of Lleida, Spain. Food. Chem. Toxicol. 2011b, 49, 1436-1442. [CrossRef] [PubMed]

320. Rubert, J.; Soriano, J.; Mañes, J.; Soler, C. Rapid mycotoxin analysis in human urine: A pilot study. Food. Chem. Toxicol. 2011, 49, 2299-2304. [CrossRef] [PubMed]

321. Solfrizzo, M.; Gambacorta, L.; Lattanzio, V.; Powers, S.; Visconti, A. Simultaneous LC-MS/MS determination of aflatoxin M1, Ochratoxin A, deoxynivalenol, de-epoxydeoxynivalenol, A and B-zearalenols and fumonisin $\mathrm{B}_{1}$ in urine as a multi-biomarker method to assess exposure to mycotoxins. Anal. Bioanal. Chem. 2011, 401, 2831-2841. [CrossRef] [PubMed]

322. Desalegn, B.; Nanayakkara, S.; Harada, K.; Hitomi, T.; Chandrajith, R.; Karunaratne, U.; Abeysekera, T.; Koizumi, A. Mycotoxin detection in urine samples from patients with chronic kidney disease of uncertain etiology in Sri Lanka. Bull. Environ. Contam. Toxicol. 2011, 87, 6-10. [CrossRef] [PubMed]

323. Duarte, S.; Alves, M.; Pena, A.; Lino, C. Determinants of Ochratoxin A exposure-A One year follow-up study of urine levels. Int. J. Hyg. Environ. Health 2012, 215, 360-367. [CrossRef] [PubMed]

324. Klapec, T.; Šarkanj, B.; Banjari, I.; Strelec, I. Urinary Ochratoxin A and ochratoxin alpha in pregnant women. Food. Chem. Toxicol. 2012, 50, 4487-4492. [CrossRef] [PubMed]

325. Abia, W.; Warth, B.; Sulyok, M.; Krska, R.; Tchana, A.; Njobeh, P.; Turner, P.; Kouanfack, C.; Eyongetah, M.; Dutton, M.; et al. Bio-monitoring of mycotoxin exposure in Cameroon using a urinary multi-biomarker approach. Food. Chem. Toxicol. 2013, 62, 927-934. [CrossRef] [PubMed]

326. Shephard, G.; Burger, H.; Gambacorta, L.; Gong, Y.; Krska, R.; Rheeder, J.; Solfrizzo, M.; Srey, C.; Sulyok, M.; Visconti, A.; et al. Multiple mycotoxin exposure determined by urinary biomarkers in rural subsistence farmers in the former Transkei, South Africa. Food. Chem. Toxicol. 2013, 62, 217-225. [CrossRef] [PubMed] 
327. Solfrizzo, M.; Gambacorta, L.; Visconti, A. Assessment of multi-mycotoxin exposure in Southern Italy by urinary multi-biomarker determination. Toxins 2014, 6, 523-538. [CrossRef] [PubMed]

328. Duarte, S.; Lino, C.; Pena, A. Ochratoxin A in food and urine: A nationwide Portuguese two-year study. World Mycotoxin J. 2015, 8, 121-132. [CrossRef]

329. Gerding, J.; Ali, N.; Schwartzbord, J.; Cramer, B.; Brown, D.; Degen, G.; Humpf, H. A Comparative study of the human urinary mycotoxin excretion patterns in Bangladesh, Germany, and Haiti using a rapid and sensitive LC-MS/MS approach. Mycotoxin Res. 2015, 31, 127-136. [CrossRef] [PubMed]

330. Gareis, M.; Martlbauer, E.; Bauer, J.; Gedek, B. Determination of Ochratoxin A in human milk. Proc. Jpn. Assoc. Mycotoxicol. 1988, 61-62. [CrossRef]

331. Breitholtz-Emanuelsson, A.; Olsen, M.; Oskarsson, A.; Palminger, I.; Hult, K. Ochratoxin A in cow's milk and in human milk with corresponding human blood samples. J. AOAC Int. 1993, 76, 842-846. [PubMed]

332. Micco, C.; Ambruzzi, M.A.; Miraglia, M.; Brera, C.; Onori, R.; Benelli, I. Contamination of human milk with Ochratoxin A. In Mycotoxins, Endemic Nephropathy and Urinary Tract Tumours; Castegnaro, M., Plestina, R., Dirheimer, G., Chernozemsky, I.N., Bartsch, H., Eds.; IARC Scientific Publications: Lyon, France, 1991; Volume 115, pp. 105-108.

333. Skaug, M.; Helland, I.; Solvoll, K.; Saugstad, O. Presence of Ochratoxin A in human milk in relation to dietary intake. Food Addit. Contam. 2001, 18, 321-327. [CrossRef] [PubMed]

334. Micco, C.; Miraglia, M.; Brera, C.; Corneli, S.; Ambruzzi, A. Evaluation of Ochratoxin A level in human milk in Italy. Food Addit. Contam. 1995, 12, 351-354. [CrossRef] [PubMed]

335. Miraglia, M.; De Dominicis, A.; Brera, C.; Corneli, S.; Cava, E.; Menghetti, E.; Miraglia, E. Ochratoxin A levels in human milk and related food samples: An exposure assessment. Nat. Toxins 1995, 3, 436-444. [CrossRef] [PubMed]

336. Skaug, M.A.; Størmer, F.C.; Saugstad, O.D. Ochratoxin A: A naturally occurring mycotoxin found in human milk samples from Norway. Acta Paediatr. 1998, 87, 1275-1278. [CrossRef] [PubMed]

337. Turconi, G.; Guarcello, M.; Livieri, C.; Comizzoli, S.; Maccarini, L.; Castellazzi, A.; Pietri, A.; Piva, G.; Roggi, C. Evaluation of xenobiotics in human milk and ingestion by the newborn. Eur. J. Nutr. 2004, 43, 191-197. [CrossRef] [PubMed]

338. Postupolski, J.; Karlowski, K.; Kubik, P. Ochratoxin A and foetal blood and in maternal milk. Rocz. Panstw. Zakl. Hig. 2006, 57, 23-30. [PubMed]

339. Galvano, F.; Pietri, A.; Bertuzzi, T.; Gagliardi, L.; Ciotti, S.; Luisi, S.; Bognanno, M.; la Fauci, L.; Iacopino, A.; Nigro, F.; et al. Maternal dietary habits and mycotoxin occurrence in human mature milk. Mol. Nutr. Food Res. 2008, 52, 496-501. [CrossRef] [PubMed]

340. Dostal, A.; Jakusova, L.; Cajdova, J.; Hudeckova, H. Results of the first studies of occurrence of Ochratoxin A in human milk in Slovakia. Bratisl. Lek. Listy 2008, 109, 276-278. [PubMed]

341. Biasucci, G.; Calabrese, G.; di Giuseppe, R.; Carrara, G.; Colombo, F.; Mandelli, B.; Maj, M.; Bertuzzi, T.; Pietri, A.; Rossi, F. The presence of Ochratoxin A in cord serum and in human milk and its correspondence with maternal dietary habits. Eur. J. Nutr. 2011, 50, 211-218. [CrossRef] [PubMed]

342. Muñoz, K.; Wollin, K.; Kalhoff, H.; Degen, G. Zum vorkommen des mykotoxins Ochratoxin A in muttermilchproben aus Deutschland. Gesundheitswesen 2013, 75, 194-197. [CrossRef] [PubMed]

343. Jonsyn, F.; Maxwell, S.; Hendrickse, R. Ochratoxin A and aflatoxins in breast milk samples from Sierra Leone. Mycopathologia 1995, 131, 121-126. [CrossRef] [PubMed]

344. El-Sayed, A.; Soher, E.; Neamat-Allah, A. Human exposure to mycotoxins in Egypt. Mycotoxin Res. 2002, 18, 23-30. [CrossRef] [PubMed]

345. Hassan, A.; Sheashaa, H.; Fattah, M.; Ibrahim, A.; Gaber, O.; Sobh, M. Study of Ochratoxin A as an environmental risk that causes renal injury in breast-fed Egyptian infants. Pediatr. Nephrol. 2006, 21, 102-105. [CrossRef] [PubMed]

346. Apostolou, E.; El-Nezami, H.S.; Ahoka, J.T.; Donohe, D.D. The evaluation of Ochratoxin A in breast milk in Victoria (Australia). Rev. Med. Vet. 1998, 149, 709.

347. Gürbay, A.; Girgin, G.; Sabuncuoğlu, S.; Şahin, G.; Yurdakök, M.; Yiğit, Ş.; Tekinalp, G. Ochratoxin A: Is it present in human breast milk samples obtained mothers from Ankara, Turkey. Toxicol. Lett. 2009, 189, 232. [CrossRef]

348. Afshar, P.; Shokrzadeh, M.; Kalhori, S.; Babaee, Z.; Saeedi Saravi, S. Occurrence of Ochratoxin A and aflatoxin M1 in human breast milk in Sari, Iran. Food Control 2013, 31, 525-529. [CrossRef] 
349. Dehghan, P.; Pakshir, K.; Rafiei, H.; Chadeganipour, M.; Akbari, M. Prevalence of Ochratoxin A in human milk in the Khorrambid Town, Fars province, South of Iran. Jundishapur J. Microbiol. 2014, 7. [CrossRef] [PubMed]

350. Navas, S.; Sabino, M.; Rodriguez-Amaya, D. Aflatoxin $\mathrm{M}_{1}$ and Ochratoxin A in a human milk bank in the city of São Paulo, Brazil. Food Addit. Contam. 2005, 22, 457-462. [CrossRef] [PubMed]

351. Muñoz, K.; Campos, V.; Blaszkewicz, M.; Vega, M.; Alvarez, A.; Neira, J.; Degen, G. Exposure of neonates to Ochratoxin A: First biomonitoring results in human milk (colostrum) from Chile. Mycotoxin Res. 2010, 26, 59-67. [CrossRef] [PubMed]

352. Andrade, P.; da Silva, J.; Caldas, E. Simultaneous analysis of aflatoxins B1, B2, G1, G2, M1 and Ochratoxin A in breast milk by high-performance liquid chromatography/fluorescence after liquid-liquid extraction with low temperature purification (LLE-LTP). J. Chromatogr. A 2013, 1304, 61-68. [CrossRef] [PubMed]

353. Iha, M.; Barbosa, C.; Heck, A.; Trucksess, M. Aflatoxin $\mathrm{M}_{1}$ and Ochratoxin A in human milk in Ribeirão Preto-SP, Brazil. Food Control 2014, 40, 310-313. [CrossRef]

354. Kuiper-Goodman, T.; Hilts, C.; Billiard, S.; Kiparissis, Y.; Richard, I.; Hayward, S. Health risk assessment of Ochratoxin A for all age-sex strata in a market economy. Food Addit. Contam. Part A Chem. Anal. Control. Expo Risk. Assess. 2010, 27, 212-240. [CrossRef] [PubMed]

355. Malir, F.; Ostry, V.; Pfohl-Leszkowicz, A.; Roubal, T. Ochratoxin A exposure biomarkers in the Czech Republic and comparison with foreign countries. Biomarkers 2012, 17, 577-589. [CrossRef] [PubMed]

356. Bauer, K.; Gekle, M.; Silbernagl, S. Ochratoxin A and kidney. In Proceedings of the 16th Mycotoxin Workshop Stuttgart-Hohenheim, Hohenheim, Germany, 16-18 May 1994.

357. Ostry, V.; Malir, F.; Roubal, T.; Skarkova, J.; Ruprich, J.; Cerna, M.; Creppy, E. Monitoring of mycotoxin biomarkers in the Czech Republic. Mycotoxin Res. 2005, 21, 49-52. [CrossRef] [PubMed]

358. Park, D.L.; Troxell, T.C.U.S. Perspective on Mycotoxin Regulatory Issues. In Mycotoxins and Food Safety; Vries, J.W., de Trucksess, M.W., Jackson, L.S., Eds.; Kluwer Academic/ Plenum Publishers: New York, NY, USA, 2002.

359. Worldwide Regulations for Mycotoxins in Food and Feed in 2003, FAO 2003. p. 27. Available online: http:/ / www.fao.org/docrep/007/y5499e/y5499e00.htm\#Contents (accessed on 12 April 2016).

360. Van Egmond, H.P. Worldwide regulation for oxhratoxin A. In Mycotoxins, Endemic Nephropathy and Urinary Tract Tumors; Castegnaro, M., Plestina, R., Dirheimer, G., Eds.; IARC Sci. Publ.: Lyon, Frace, 1991; Volume 115, pp. 331-336.

361. Duarte, S.; Lino, C.; Pena, A. Mycotoxin food and feed regulation and the specific case of Ochratoxin A: A review of the worldwide status. Food Addit. Contam. Part A Chem. Anal. Control. Expo Risk. Assess. 2010, 27, 1440-1450. [CrossRef] [PubMed]

362. Li, X.; Zhao, L.; Fan, Y.; Jia, Y.; Sun, L.; Ma, S.; Ji, C.; Ma, Q.; Zhang, J. Occurrence of mycotoxins in feed ingredients and complete feeds obtained from the Beijing region of China. J. Anim. Sci. Biotechnol. 2014, 5, 37. [CrossRef] [PubMed]

363. Codex Allimentarius. General Standard for Contaminants and Toxins in Food and Feed, CODEX STAN 193-1995, 1995-2015.

364. Codex Allimentarius. Code of Practice for the Prevention and Reduction of Mycotoxin Contamination in Cereals Including Annexes on Ochratoxin A, Zearalenone, Fumonisins and Tricothecenes, CAC/RCP 51-2003, 2003-2014.

365. Codex Allimentarius. Code of Practice for the Prevention and Reduction of Ochratoxin A Contamination in Wine, CAC/RCP 63-2007, 2007.

366. Codex Allimentarius. Code of Practice for the Prevention and Reduction of Ochratoxin A Contamination in Coffee, CAC/RCP 69-2009, 2009.

367. Codex Allimentarius. Code of Practice for the Prevention and Reduction of Ochratoxin A Contamination in Cocoa, CAC/RCP 72-2013, 2013.

368. Food and Agriculture Organization/World Health Organisation. 2007-2014. Available online: http://www. fao.org/fao-whocodexalimentarius/standards/list-of-standards/en (accessed on 12 April 2016).

369. European Union. Commission Regulation (EC) No 472/2002 of 12 March 2002 setting maximum levels for certain contaminants in foodstuffs (Text with EEA relevance). Off. J. Eur. Union 2002, L 75, 18-20.

370. European Union. Commission Regulation (EC) No 466/2001 of 8 March 2001 setting maximum levels for certain contaminants in foodstuffs (Text with EEA relevance). Off. J. Eur. Union 2001, L 77, 1-13. 
371. European Union. Commission Regulation (EC) No 1881/2006 of 19 December 2006 setting maximum levels for certain contaminants in foodstuffs (Text with EEA relevance). Off. J. Eur. Union 2006, L364, 5-24.

372. Verstraete, F. Decision-making process and overview of recent and future European Union legislation on mycotoxins in food and feed. In The Mycotoxin Factbook: Food E Feed Topics; Barug, D., Bhatnagar, D., Egmond, H.P., van Kamp, J.W., van der Osenbruggen, W.A., Visconti, A., Eds.; Wageningen Academic Publishers: Wageningen, The Netherlands, 2006.

373. European Unio. Commission Recommendation No 2006/576/EC of 17 August 2006 on the presence of deoxynivalenol, zearalenone, Ochratoxin A, T-2 and HT-2 and fumonisins in products intended for animal feeding, (Text with EEA relevance). Off. J. Eur. Union 2006, C 229, 7-9.

374. Encyclopedia of Food Microbiology, 2nd ed.; Batt, C.A., Tortello, M.L., Eds.; Academic Press: San Diego, CA, USA, 2014.

375. Dohlman, E. Mycotoxin Hazards and Regulations. Impacts on Food and Animal Feed Crop Trade. In International Trade and Food Safety; Buzby, J., Ed.; U.S. Dept. of Agriculture, Economic Research Service: Washington, DC, USA, 2003; pp. 97-108.

376. Wu, F. A tale of two commodities: How EU mycotoxin regulations have hurt, or helped, food industries. In Proceedings of the Fourth Conference, Cincinnati, OH, USA, November 6-8, 2006.

377. Van Egmond, H.; Schothorst, R.; Jonker, M. Regulations relating to mycotoxins in food. Anal. Bioanal. Chem. 2007, 389, 147-157. [CrossRef] [PubMed]

378. Köszegi, T.; Poór, M. Ochratoxin A: Molecular interactions, mechanisms of toxicity and prevention at the molecular level. Toxins 2016, 8, 111. [CrossRef] [PubMed]

379. Tozlovanu, M. Evaluation du Risque de Contamination Alimentaire en Mycotoxines Néphrotoxiques et Cancérogènes (nOtamment l'Ochratoxine A): Validation de Biomarqueurs D'exposition et d'Effet. Ph.D. Thesis, Undergraduate, Institut National Polytechnique de Toulouse, France, 2008.

380. Woo, C.S.J.; El-Nezami, H. Maternal-fetal cancer risk assessment of Ochratoxin A during pregnancy. Toxins 2016, 8, 87. [CrossRef] [PubMed]

(C) 2016 by the authors; licensee MDPI, Basel, Switzerland. This article is an open access article distributed under the terms and conditions of the Creative Commons Attribution (CC-BY) license (http://creativecommons.org/licenses/by/4.0/). 